\title{
PRODUÇÃo CIENTÍFICA NA ÁREA DE ODONTOLOGIA PREVENTIVA E SOCIAL. BRASIL, 1986-1993
}

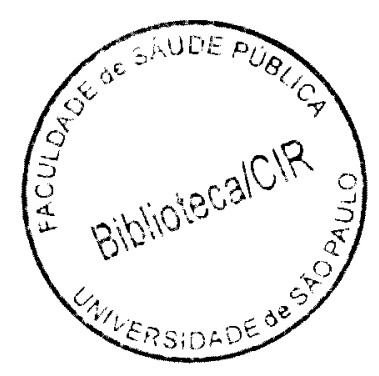

Tese apresentada à Faculdade de Saúde Pública da Universidade de São Paulo para concorrer ao título de Doutor em Saúde Pública.

Autor: Paulo Capel Narvai

Orientador: Professor Associado Eurivaldo Sampaio de Almeida

São Paulo

1997 
À memória da minha mãe, Judith.

Para Raquel e Julia. 
Realizar este trabalho teria sido muito mais dificil sem o apoio, o estímulo, as criticas e as sugestões de várias pessoas, em diferentes momentos e lugares. Sou imensamente grato a todos, desde a Dona Albertina Maria de Azevedo, que além de pacientemente manter a limpeza da sala de trabalho soube carinhosamente manter vivas e radiantes as violetas da janela, até Caetano Veloso pela deliciosa companhia de Fina Estampa, passando pèla gentileza da atenção do Etevaldo Sousa dos Santos, do Antonio Carlos dos Santos, e dos demais funcionários do Departamento de Prática de Saúde Pública da USP. Não poderia, ainda, deixar sem menção o agradável convívio e a confiança do meu orientador Prof. Assoc. Eurivaldo Sampaio de Almeida, que adotou comigo um funcional sistema de "liberdade vigiada", muito eficaz, além das indispensáveis participações de Aracy Witt de Pinho Spínola, Maria da Penha C. Vasconcellos, Roberto A. Castellanos, Paulo Frazão, Yvette Viegas, Deborah R. A. D. Silva, Paulo A. C. Fortes, Marco Aurélio A. Peres, Thomaz Chianca e Ercília L. Dini e o apoio e compreensão de Evelin N. Castro Sá e Pedro M. L. Germano. Quero expressar também meu reconhecimento e respeito ao trabalho de todos os autores dos artigos aqui abordados. Todos, sem exceção, merecem esse reconhecimento pela ousadia da produção intelectual e por contribuirem, de alguma maneira, para o desenvolvimento do pensamento crítico em nosso meio. Meu especial agradecimento também aos atenciosos funcionários das bibliotecas por onde andei e aos anonimos trabalhadores que me auxiliaram a encontrá-las quando, perdido pelos caminhos, thes pedi informações para acertar o rumo. Nesta página de agradecimentos devo ainda registrar, lamentando, que a política de financiamento de pesquisas cientificas em vigor no Brasil tenha impedido esta investigação de ter o apoio financeiro das agências que deveriam fazê-lo. 


\section{RESUMO}

A produção científica brasileira na área de odontologia preventiva e social, no período de 1986 a 1993, foi identificada e analisada com o objetivo de verificar a hipótese de essa produção ter contemplado as temáticas relativas às políticas de saúde e ao sistema de saúde, contribuindo assim para a compreensão e superação dos problemas enfrentados pelo país no âmbito da saúde bucal coletiva. A abordagem dessa produção foi feita através de artigos publicados em revistas científicas brasileiras, dirigidas à odontologia ou à saúde pública/coletiva lato sensu, admitindo-se que tais artigos são indicadores da referida produção. Realizou-se um survey analítico através do qual foi possível conhecer, dentre outros aspectos, a origem institucional dos autores, suas titulações e preocupações temáticas, os tipos de pesquisas realizadas e as modalidades de artigos delas decorrentes, bem como suas fontes de financiamento. O período estudado abrangeu o intervalo entre a I e a II Conferência Nacional de Saúde Bucal. Foram analisados 386 artigos, publicados em 19 periódicos, por pelo menos 866 autores. Mais de três quartas partes dessa produção teve origem na universidade pública. $R G O$ foi o periódico que mais publicou nesta área, seguido pela Revista da $A P C D$. Dos textos, 56,7\% corresponderam a artigos originais. Revisões de literatura e ensaios somaram $30,3 \%$. Mais da metade dos autores desenvolviam suas atividades no estado de São Paulo. O sexo masculino predominou. Admite-se deficiência quantitativa no conjunto da produção da área, a qual se situa em torno de no máximo $50 \%$ do seu potencial. A politica de saúde foi tema específico em apenas 3 artigos $(0,8 \%)$ e sistema de saúde em $7(1,8 \%)$. Tais resultados, modestíssimos e indicativos de desinteresse e/ou dificuldades dos autores em abordá-los, levaram à rejeição da hipótese, concluindo-se que, no crucial período histórico de reconquista e consolidação das liberdades democráticas, a produção científica odontológica não se ocupou devidamente das questões relacionadas às políticas de saúde e ao sistema de saúde brasileiro. 


\section{SUMMARY}

The Brazilian scientific literature on social and preventive dentistry, from 1986 to 1993, was identified and analyzed in order to verify the hypothesis: "the scientific production contemplated themes related to health policy and the national health system, contributing to improve understanding and to reduce the problems faced by the country in the field of collective oral health." Published scientific articles directed to dentistry or to the public/collective health field, were used as the unit of analysis for the study. General reports and other informal publications were not included in the study. An analitic survey was conducted taking into consideration, among others, the following variables: author's institutional origin; author's title; author's areas of interest; type of research conducted; type of article; study's financial support. The articles reviewed were published between the First and the Second National Oral Health Conference. There were 386 articles published in 19 journals, by at least 866 authors. More than $75 \%$ of the studies came from public universities. $R G O$ was the biggest publisher in this field, followed by the Revista da APCD. Original articles accounted for $56.7 \%$ of the studies, while $30.3 \%$ were reviews and essays. The majority of the authors were from the state of São Paulo. Male writers predominated. "Quantitative deficiency" was found, since the scientific production stayed below $50 \%$ of its potential. Health policy was considered a specific issue in only $3(0.8 \%)$ articles while $7(1.8 \%)$ articles discussed the national health system. These last results indicate the rejection of the hypothesis. The author discusses lack of interest, as well as methodological and political difficulties in conducting research on these two issues as possible reasons for the study findings. 


\section{ÍNDICE}

Página

1. INTRODUÇÃO

$\begin{array}{lr}\text { 2. HIPÓTESE } & 15\end{array}$

$\begin{array}{lr}\text { 3. OBJETIVOS } & 18\end{array}$

4. MATERIAL E MÉTODO 19

$\begin{array}{ll}\text { 4.1. Artigos } & 24\end{array}$

$\begin{array}{ll}\text { 4.2. Periódicos } & 30\end{array}$

$\begin{array}{ll}\text { 4.3. Bibliotecas } & 35\end{array}$

4.4. A Área de Odontologia Preventiva e Social 38

4.5. Procedimentos 43

5. Resultados E Discussão 46

5.1. Periódicos 47

5.2. Autores $\quad 50$

$\begin{array}{lr}\text { 5.3. Artigos } & 58\end{array}$

$\begin{array}{ll}\text { 5.4. Temas } & 76\end{array}$

6. CONCLUSÕES

7. REFERÊNCIAS BIBLIOGRÁFICAS 96

ANEXO I - Instrumento para Coleta dos Dados A-1

ANEXO 2 - Lista de Temas Predominantes A-2 


\section{ÍNDICE DE TABELAS}

\section{NÚMERO E TÍTULO DA TABELA}

1. Artigos sobre Odontologia Preventiva e Social em periódicos brasileiros selecionados, no período 1986-1993 segundo o ano de publicação

2. Autores de artigos sobre Odontologia Preventiva e Social em periódicos brasileiros selecionados, no periodo 1986-1993, segundo o vínculo institucional e a posição ocupada na autoria

3. Autores de artigos sobre Odontologia Preventiva e Social em periódicos brasileiros selecionados, no periodo 1986-1993, segundo a respectiva titulação e a posição ocupada na autoria

4. Autores de artigos sobre Odontologia Preventiva e Social em periódicos brasileiros selecionados, no período 1986-1993, segundo a participação na autoria e o sexo

5. Primeiros autores de artigos sobre Odontologia Preventiva e Social em periódicos brasileiros selecionados, no periodo 1986-1993, segundo a localização geográfica da instituição na qual o autor desenvolve atividades profissionais

6. Artigos sobre Odontologia Preventiva e Social em periódicos brasileiros selecionados, no periodo 1986-1993, segundo o tipo de artigo e sua relação com dissertações ou teses

7. Artigos sobre Odontologia Preventiva e Social em periódicos brasileiros selecionados, no periodo 1986-1993, segundo o tipo de artigo e a origem institucional do primeiro autor

8. Artigos sobre Odontologia Preventiva e Social em periódicos brasileiros selecionados, no periodo 1986-1993, segundo o tipo de pesquisa que lhes deram origem

9. Artigos sobre Odontologia Preventiva e Social em periódicos brasileiros selecionados, no periodo 1986-1993, segundo a adequação do título

10. Artigos sobre Odontologia Preventiva e Social em periódicos brasileiros selecionados, no período 1986-1993, segundo a participação de agências de financiamento nas pesquisas que os originaram

11. Artigos sobre Odontologia Preventiva e Social em periódicos brasileiros selecionados, no período 1986-1993, segundo a titulação do primeiro autor e o emprego de metodologia adequada

12. Artigos sobre Odontologia Preventiva e Social em periódicos brasileiros selecionados, no período 1986-1993, segundo o vínculo institucional do primeiro autor e a adequação da metodologia

13. Artigos sobre Odontologia Preventiva e Social em periódicos brasileiros selecionados, no periodo 1986-1993, segundo domínio temático

14. Artigos sobre Odontologia Preventiva e Social em periódicos brasileiros selecionados, no periodo 1986-1993, segundo o tema predominante 


\section{SIGLAS}

\begin{tabular}{|c|c|}
\hline ADA & - American Dental Association \\
\hline AIDS & - Síndrome da Imunodeficiência Adquirida \\
\hline ANEO & - Assembléia Nacional de Especialidades Odontológicas \\
\hline APCD & - Associação Paulista de Cirurgiões-Dentistas \\
\hline CAPES & - Coordenação de Aperfeiçoamento de Pessoal de Nível Superior \\
\hline CEDROS & - Rede de Centros de Desenvolvimento de Recursos Odontológicos para o Sistema de Saúde \\
\hline CFE & - Conselho Federal de Educação \\
\hline $\mathrm{CFO}$ & - Conselho Federal de Odontologia \\
\hline $\mathrm{CNPq}$ & - Conselho Nacional de Desenvolvimento Científico e Tecnológico \\
\hline $\mathrm{CNS}$ & - Conferência Nacional de Saúde \\
\hline CNSB & - Conferência Nacional de Saúde Bucal \\
\hline EAP & - Escola de Aperfeiçoamento Profissional \\
\hline ENATESPO & - Encontro Nacional de Administradores e Técnicos do Serviço Público Odontológico \\
\hline FAPESP & - Fundação de Amparo à Pesquisa do Estado de São Paulo \\
\hline FO & - Faculdade de Odontologia \\
\hline MPAS & - Ministério da Previdência e Assistência Social \\
\hline $\mathrm{OM}$ & - Odontólogo Moderno \\
\hline OPAS & - Organização Pan-Americana de Saúde \\
\hline OPS & - Odontologia Preventiva e Social \\
\hline RBO & - Revista Brasileira de Odontologia \\
\hline ROBRAC & - Revista Odontológica do Brasil Central \\
\hline SBPC & - Sociedade Brasileira para o Progresso da Ciência \\
\hline SUDS & - Sistema Unificado e Descentralizado de Saúde \\
\hline SUS & - Sistema Único de Saúde \\
\hline UFBA & - Universidade Federal da Bahia \\
\hline UFMG & - Universidade Federal de Minas Gerais \\
\hline UNESP & - Universidade Estadual Paulista Júlio de Mesquita Filho \\
\hline UNICAMP & - Universidade Estadual de Campinas \\
\hline USP & - Universidade de São Paulo \\
\hline
\end{tabular}


Falo assim sem saudade Falo assim por saber Se muito vale o já feito Mais vale o que será $E$ o que foi feito É preciso conhecer Para melhor prosseguir

Milton Nascimento e Fernando Brant, em $O$ que foi feito deverá 


\section{INTRODUÇÃO}

As liberdades democráticas, sobrestadas no Brasil com o golpe militar de março de 1964 , começaram a ser reconquistadas no final dos anos 70 e foram impulsionadas, em 1982, com a realização de eleições para governadores estaduais. Entretanto, somente com a promulgação da Constituição de 1988, o "Estado Democrático de Direito", inscrito no art. $1^{\circ}$ da Carta Magna, viria a encerrar formalmente o período de mais de duas décadas de didatura

Os 24 anos de supressão de direitos e garantias democráticas marcaram profundamente o país e produziram efeitos em todas as dimensões da vida nacional, notadamente a cultura, sobre a qual se abateu rigoroso controle e implacável censura.

Também a produção científica, dimensão particular da vida cultural, se ressentiu da falta de democracia, não tendo sido poucos os produtores pessoalmente molestados e perseguidos. Houve prisões, torturas e desaparecimentos conforme é, no final do século, de amplo conhecimento público.

No setor da saúde, a produção científica foi atingida em várias dimensões, seja pela inibição ou mesmo proibição à abordagem de determinados temas, seja pela censura à divulgação de resultados de pesquisas. Nesse aspecto, o episódio emblemático do período foi a proibição de informar sobre a epidemia de meningite em São Paulo, em 1972.

Com o fim do período ditatorial, ressurgiram as condições favoráveis à livre produção e manifestação do pensamento, que voltou a se ocupar dos problemas do país e a contribuir para a busca de soluções. No plano das políticas e dos serviços de saúde, 
as novas condições históricas operaram mudanças significativas no sistema de saúde brasileiro.

Com efeito, as mobilizações populares em torno da campanha das "Diretas Já" (1984), reivindicando eleições diretas para a Presidência da República, induziram importantes transformações no arcabouço jurídico-institucional e marcaram a cultura política do País. O impeachment, em 1992, do Presidente Fernando Collor de Mello, eleito em 1989, que surpreendeu pelo ineditismo e despertou a atenção em todo o mundo, é apenas um exemplo dessas mudanças. A campanha das "Diretas Já" fortaleceu e ajudou a impulsionar um vigoroso movimento, denominado "Reforma Sanitária", que se vinha gestando na sociedade brasileira desde meados dos anos 70. A partir de núcleos de oposição política ao regime militar com atuação no setor saúde, o movimento de "Reforma Sanitária" conseguiu articular diferentes segmentos sociais em torno de um conjunto de proposições sintetizadas na consigna "pela democratização da saúde e da sociedade". Esse conjunto de proposições teve na VIII Conferência Nacional de Saúde $(\mathrm{CNS})^{a}$, realizada em Brasília em março de 1986, um momento privilegiado de discussões e pactuação política. Foi de tal ordem essa pactuação política que as principais deliberações da VIII CNS tiveram acolhida favorável entre os parlamentares eleitos para a Assembléia Nacional Constituinte de modo que, quando esses constituintes promulgaram, em 1988, a Constituição da República Federativa do Brasil, ali estavam, consagradas na Carta Magna, as principais deliberações da VIII CNS. Em síntese, referiam-se à:

\footnotetext{
a) CONFERÊNCIA Nacional de Saúde, $8^{\mathrm{a}}$, Brasília, DF, 1986. Anais. Brasilia, Centro de Documentação do Ministério da Saúde, 1987. 430p.
} 
- saúde como um direito de todos e um dever do Estado;

- criação de um sistema único de saúde (SUS);

- gestão descentralizada do SUS, com comando único em cada esfera de governo;

- integralidade das ações de saúde, com prioridade para as medidas preventivas; - participação da comunidade nas decisões relativas à saúde.

Posteriormente, em 1990, as Leis Federais $8080^{b}$ e $8142^{c}$ viriam a regulamentar esses preceitos constitucionais e estabelecer novas bases legais para o desenvolvimento do sistema de saúde brasileiro, processo atualmente em curso e pleno de ambigüidades e contradições.

Ainda em 1986, no contexto da VIII Conferência Nacional de Saúde e como parte do seu processo, foi realizada em Brasília (10 a 12 de outubro) a I Conferência Nacional de Saúde Bucal (CNSB). Precedida por pré-conferências estaduais, que elegeram 286 delegados à etapa nacional, a I CNSB teve, segundo os organizadores, “mais de 1.000 participantes". Os delegados (65\% dos quais eram cirurgiões-dentistas) aprovaram um Relatório Final ${ }^{83}$ contendo uma análise do diagnóstico de saúde bucal no Brasil; a saúde bucal como direito de cidadania; a inserção das ações odontológicas no sistema de saúde; e, o financiamento do setor. Essencialmente, o documento da I CNSB reiterava as críticas ao modelo hegemônico de prática odontológica vigente no País,

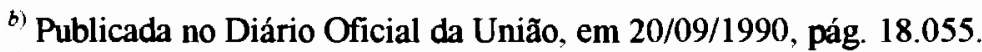

c) Publicada no Diário Oficial da União, em 31/12/1990, pág. 25.694.
} 
descrito na VII Conferência Nacional de Saúde (Brasília, março de 1980). Segundo a VII CNS ${ }^{85}$, a prática predominante no Brasil “caracteriza-se, em traços gerais, pela:

"INEFICÁCIA - Na medida em que não responde à resolução ou redução, em níveis significativos, dos problemas de saúde bucal da população.

"INEFICIÊENCIA - Uma vez que é de alto custo e baixíssimo rendimento.

"DESCOORDENACÃO - Decorrente da multiplicidade de órgãos que atuam superpostamente tanto a nivel normativo quanto operacional.

"MÁ DISTRIBUIÇÃO - Uma vez que as unidades prestadoras de serviço se localizam nos pólos de desenvolvimento, ou em torno deles, deixando ao abandono as áreas rurais ou marginalizadas dos grandes centros, que, assim, são obrigadas a buscar sistemas alternativos de atenção.

"BAIXA COBERTURA - Na medida em que não consegue dar assistência nem à demanda espontânea, quanto mais àquela que é a mais significativa e que não chega a ser efetiva.

"ALTA COMPLEXIDADE - Uma vez que faz uso de uma tecnologia complexa e sofisticada.

"ENFOQUE CURATIVO - Em razão do abandono a que relega o emprego de métodos preventivos hoje disponíveis e já sobejamente comprovados como de enorme eficácia e eficiência.

“CARÁTER MERCANTILISTA - Na medida em que faz da saúde um bem de troca sujeito às leis econômicas não só no campo da iniciativa privada, como 
também no da pública, que o estimula mediante mecanismos de compra de seus serviços.

"CARÁTER MONOPOLISTA - Que se traduz na resistência à transferência de conhecimentos e à sua utilização por parte de outros tipos de recursos humanos, que não o profissional de nível superior, numa opção que fere o principio de divisão do trabalho já reconhecido e utilizado largamente por outros setores das ciências médicas.

“INADEQUAÇÃO NO PREPARO DOS RECURSOS HUMANOS - Que a nivel superior são formados de maneira desvinculada das reais necessidades do Pais, precocemente direcionados para as especialidades e totalmente dissociados das caracteristicas dos serviços onde deverão atuar e que, a nível auxiliar e técnico, insiste na utilização de mecanismos formais de preparação já superados por procedimentos comprovadamente mais ágeis e de menor custo como o treinamento ou preparação em serviço.

"Finalmente caracteriza-se o modelo odontológico atual pela dependência externa na medida em que baseia seus modelos de atuação, orienta a formação de seus recursos humanos e emprega uma tecnologia com insumos e equipamentos importados, cujas condições em nada reproduzem as existentes em paises não desenvolvidos ou em desenvolvimento, reforçando assim todo um contexto de dependência econômica e cultural que entrava e desestimula criatividade na busca de soluções ajustadas às características de nosso país. " 
Ao mesmo tempo em que, nesse plano mais geral das Conferências de Saúde e das definições legais, o sistema de saúde brasileiro assumia nova configuração com participação da sociedade civil, no cotidiano das instituições de saúde enfrentavam-se os enormes desafios da sua implementação. E aos produtores de conhecimentos, aos pesquisadores, colocavam-se novas demandas as quais, originadas nas novas realidades, emergiam das vicissitudes e dilemas do SUS, dos seus avanços e retrocessos, dos recursos financeiros para desenvolvê-lo, dos recursos humanos que lhe dão vida, das tecnologias utilizadas, enfim, do modelo de atenção à saúde que, nos anos 80 e 90 do século XX, se pretendeu desenvolver no Brasil.

Internamente ao setor saúde, no âmbito mais restrito da produção científica na área odontológica, qual foi impacto dessas profundas transformações ocorridas na vida nacional pós-didatura, no desenvolvimento das pesquisas e nas opções temáticas dos pesquisadores, tendo por referência as políticas de saúde e as mudanças do sistema de saúde?

Esta é a questão central de que se ocupa a presente investigação científica, e esse é, em linhas gerais, o contexto histórico no interior do qual se localiza o seu objeto.

Tal contextualização é necessária pois, conforme VELHO ${ }^{393}$ (1989), "as informações sobre ciência devem ser tomadas no contexto social mais amplo, que também deve servir de pano de fundo para a interpretação de qualidade da ciência."

Tendo em vista o interesse pelas políticas de saúde e as mudanças do sistema de sauide é feito um recorte do conjunto da produção científica na área odontológica para 
uma de suas especialidades, justamente aquela à qual estão afetas, enquanto objeto, as politicas e o sistema de saúde: a odontologia preventiva e social (OPS).

A opção pela OPS decorre do fato de essa área, mais que as outras, ter como seu objeto prioritário de intervenção social, ensino e pesquisa, as dimensões políticas e sócio-economicas da prática odontológica.

No plano histórico, a área de odontologia preventiva e social começou a se constituir com a criação das disciplinas com essa denominação ou similar, nos cursos de odontologia, a partir da metade do século XX.

Surgidas inicialmente nas escolas de odontologia dos Estados Unidos, as disciplinas de odontologia preventiva e social foram introduzidas nos programas de formação dos cirurgiões-dentistas brasileiros, e em toda a América Latina, sob influencia da Organização Pan-Americana da Saúde (OPAS) e da Fundação Kellogg 251. Durante os anos 60 a OPAS promoveu, com apoio da Associação Latinoamericana de Odontologia e da Fundação Kellogg, seminários latino-americanos sobre ensino odontológico. O segundo desses seminários ocorreu em 1964 na Cidade do México.

No Informe Final do Segundo Seminário 264 é dito que:

"Os aspectos preventivos e sociais constituem a base de todo o ensino e fins odontológicos. Mediante eles o futuro cirurgião-dentista se compenetrará dos problemas sociais, identificará suas causas e desenvolverá projetos para sua solução em beneficio da comunidade.

"Dado o crescimento vertiginoso da população da América Latina, considerase impossível que os problemas de saúde bucal possam ser resolvidos por meio 
do tratamento curativo. É por isso imperativo recorrer às técnicas preventivas e de saúde pública e também que o cirurgião-dentista, ademais de sua função assistencial e preventiva, assuma responsabilidades como membro da comunidade.

"Para integrar melhor os conceitos da odontologia preventiva e social nos planos de ensino, considerou-se necessário criar uma Unidade ou Departamento para impulsionar e correlacionar esses aspectos com as demais matérias e corrigir e aumentar o plano o necessário para formar o cirurgiãodentista que hoje se requer (...)"

A finalidade de tais disciplinas seria 264 :

"(...) Inculcar nos futuros cirurgiões-dentistas uma firme atitude preventiva mediante o esforço coordenado de todos os Departamentos da Faculdade ou Escola, com a finalidade de tornar a prevenção uma verdadeira filosofia da profissão [e] despertar o sentido da responsabilidade e a consciência sociais do cirurgião-dentista (...)"

Tais afirmações traduzem, com efeito, a grande expectativa existente naquele contexto histórico não apenas em nosso País como de resto em toda a América Latina, com a introdução de disciplinas de odontologia preventiva e social, objetivando melhor adequar a formação de profissionais odontologistas às necessidades sócioepidemiológicas das populações da América Latina. 
Outra expectativa, igualmente importante no caso brasileiro, relaciona-se à produção de conhecimentos a partir das singulares características das diferentes regiões do País. Havia e há compreensão da necessidade de não permanecer dependente da produção científica estrangeira, ainda que o intercâmbio e cooperação internacional sejam desejáveis

Nesse sentido cabe considerar que, mesmo reconhecendo-se que a responsabilidade por essa produção não é exclusiva da Universidade, é legítimo esperar dela liderança nesse aspecto. Certamente, há pesquisadores nos serviços de saúde mas é inegável que a grande expectativa sobre tal produção volta-se para as universidades brasileiras.

Merece registro também o fato de que, apesar de as proposições da OPAS terem sido apresentadas no início dos anos 60, apenas em 1982, através da Resolução 04/82, de 03/09/1982, o Conselho Federal de Educação (CFE) fixou o currículo mínimo ao qual estão obrigados todos os cursos de odontologia em desenvolvimento no País ${ }^{88}$. Dentre as exigências do CFE está a inclusão de disciplinas da área de "odontologia preventiva e social" em todos os cursos. A finalidade básica, evidente, ainda que tardia, é alterar as características epidemiológicas atuais, através do ensino, da pesquisa e da prestação de serviços às comunidades.

A obrigatoriedade de disciplinas de OPS nos cursos de odontologia fez com que, à medida que foi sendo ampliado o número de cursos em todo o país, também foi sendo formado um contingente de especialistas na matéria, dos quais se espera contribuições significativas nos planos acadêmico e intelectual. 
Para se compreender o potencial da produção de conhecimentos nessa área no Brasil, é preciso considerar que o país contava, em 1993, com 86 (oitenta e seis) cursos de graduação em odontologia. No periodo de 1985 a 1989 foram colocados anualmente, em média, 5.419 novos cirurgiões-dentistas no mercado de trabalho 61 . Aproximadamente $11 \%$ dos dentistas do mundo encontram-se distribuídos pelas macrorregiões do Brasil, concentrando-se especialmente no sudeste 251 . Apesar disso, há unanimidade no reconhecimento de que o quadro epidemiológico bucal precisa ser alterado e que tais mudanças implicam transformar a prática odontológica e exigem a intervenção planejada do poder público ${ }^{288}$. Na I Conferência Nacional de Saúde Bucal (I CNSB, Brasilia, outubro de 1986), referida anteriormente, tal quadro foi caracterizado como "caótico"83.

Ao tratar da produção científica odontológica, no tema 3 - "Reforma Sanitária: Inserção da odontologia no Sistema Único de Saúde", os participantes da I CNSB manifestaram-se pela:

“(..) 20. Reciclagem dos quadros docentes.

21. Cursos de pós-graduação voltados para o social, de acordo com a realidade epidemiológica do país.

22. Serviço público integrado ao ensino e à pesquisa.

23. Formulação de uma politica nacional de pesquisa e desenvolvimento tecnológico, efetuada através de hierarquização sócio-epidemiológica, de acordo com a realidade de saúde bucal da população brasileira.

24. Descentralização na aplicação de recursos para a pesquisa. 
25. Divulgação da informação cientifica no sentido de subsidiar o desenvolvimento dos programas de nivel local.

26. Incentivo à pesquisa nas universidades para padronização de insumos básicos apropriados, de forma progressiva, até abranger a tecnologia de ponta usada na odontologia (...)"

Cabe menção ainda, nesse sentido, ao que os 792 delegados à II Conferência Nacional de Saúde Bucal (Brasília, setembro de 1993), eleitos em 24 Conferências Estaduais preparatórias, aprovaram sobre ciência e tecnologia e que consta do Relatório Final ${ }^{84}$ daquele evento:

"O desenvolvimento tecnológico das práticas de saúde bucal deve ser visto como parte fundamental do processo de democratização do saber odontológico e deve compreender não apenas os insumos materiais necessários à realização da consulta e dos procedimentos odontológicos, mas deve englobar as tecnologias do cuidado, tecnologias de espaço fisico, as de formação e as de organização do trabalho, na perspectiva de que este desenvolvimento vise tornar apropriadas essas tecnologias e assim serem disponibilizadas à população usuária com melhoria na qualidade do atendimento.

"Reitera-se que a produção do conhecimento deve estar voltada para a realidade do país de forma prioritária, sem que se despreze a pesquisa básica e a de ponta, a fim de que se possa romper com a dependência que ainda hoje existe nas relações entre o Brasil e os paises desenvolvidos. 
"Ainda com relação ao desenvolvimento tecnológico em saúde bucal é necessário atender às seguintes propostas:

“- O conjunto dos bens e serviços que a Odontologia é capaz de produzir devem ser integralmente colocados à disposição da população na medida das suas necessidades, sem o que não se pode pensar na democratização $e$ equidade da atenção bucal;

“- Buscar a padronização e a utilização de equipamentos resistentes, simples e de fácil mamutenção, e que o instrumental utilizado seja adequado em quantidade e qualidade, respeitando os principios de racionalização;

“- Viabilizar um projeto de incentivos que vise a redução do custo dos medicamentos, materiais e insumos utilizados em Odontologia, com ênfase aos produtos básicos e de prevenção, e adoção de providências com vistas ao estabelecimento das articulações necessárias à sua aprovação nos fóruns competentes;

“- Implantar uma política nacional de pesquisa e desenvolvimento tecnológico voltada para produção de equipamentos e produtos necessários à prática odontológica, bem como a pesquisa sobre determinantes gerais do processo saúde-doença bucal. Institutos de Pesquisa e Universidades, em parceria com os municipios, devem desenvolver tecnologias para produção, em laboratórios públicos, de insumos utilizados na atenção básica em saúde bucal nas áreas de alopatia, homeopatia e fitoterapia."

Assim, é compreensível que haja grande expectativa em relação ao trabalho dos docentes na área de "odontologia preventiva e social", tanto em relação ao seu papel no 
ensino quanto em relação à sua produção científica, em conformidade aliás com a exigência legal contida na Lei $5.540^{d}$, de $28 / 11 / 68$, cujo art. $2^{\circ}$ estabelece claramente que o ensino superior é indissociável da pesquisa.

Cabe registrar, a propósito, o que consta do Relatório Final do $5^{\circ}$ ENATESPO Encontro Nacional de Administradores e Técnicos do Serviço Público Odontológico (Recife, PE, 23 a 26/08/1988) 118 .

"(...) Deve haver empenho na promoção de cursos, encontros e seminários, cujos objetivos sejam, entre outros, tornar o pessoal odontológico adequado social, técnica e cientificamente às necessidades dos usuários, compreendidos enquanto pessoas. Tal empenho torna-se ainda mais necessário na medida em que a Universidade não vem cumprindo esse papel (...) A integração da Universidade ao SUDS é imprescindivel, devendo ser viabilizada a partir das propostas do setor saúde e levando em conta as necessidades e objetivos do sistema unificado."

GARRAFA e MOYSÉS ${ }^{146}(1996)$ registram que, "até o final dos anos 50, a Argentina era a principal liderança odontológica da América Latina. A partir dai, no entanto, o eixo acadêmico foi lentamente mudando de direção, passando a apontar o Brasil como a nova referência continental sobre a matéria para os países industrializados. Todo este progresso não veio por acaso ou por retrocesso dos nossos vizinhos platinos. Esta evolução foi construida com muito trabalho e persistência, a partir de dois aspectos fundamentais: inicialmente, com o fortalecimento do ensino

\footnotetext{
${ }^{d)}$ Publicada no Diário Oficial da União, em 29/11/1968, pág. 10.369.
} 
universitário público e, alguns anos mais tarde, com a organização de escolas de aperfeiçoamento profissional dentro das entidades associativas de classe.

"Com relação ao primeiro aspecto acima apontado, principalmente a partir dos anos 70 cresceu ano após ano o número de professores universitários que passaram a viajar ao exterior à procura de novos conhecimentos técnicocientificos. É indispensável ressaltar que as viagens da maioria desses docentes e profissionais somente foi possivel, com a manutenção dos salários públicos dos mesmos nas suas instituições de origem e/ou com bolsas de estudos proporcionadas por órgãos financiadores estatais como o CNPq ou a CAPES.

"Não se dispõe de estudos pertinentes se o retorno deste investimento deu-se para o Estado através da transmissão ou duplicação coletiva dos conhecimentos adquiridos, ou se em beneficio exclusivo do próprio interessado no exercicio de atividades diretamente remuneradas em consultório privado $(\ldots) "$

Embora as considerações de GARRAFA \& MOYSÉS sejam abrangentes e extrapolem a dimensão específica da área de odontologia preventiva e social certamente contemplam-na, aplicando-se-lhe. Ainda que esta investigação não apresente respostas aos questionamentos dos referidos autores, deve contribuir para ampliar o conhecimento sobre aspectos relevantes da política brasileira de ciência e tecnologia no âmbito odontológico. Esta é, em síntese, sua finalidade, cujos objetivos convergem para as temáticas relacionadas às políticas de saúde e ao sistema de saúde brasileiro. 


\section{HIPÓTESE}

Em relação especificamente à área de odontologia preventiva e social qual tem sido a produção da Universidade brasileira? Qual tem sido a participação das disciplinas de odontologia preventiva e social nesse processo? Além da Universidade, outras instituições têm participado da produção científica nessa área. Quais são essas instituições? Quem vem fazendo investigação científica na área de odontologia preventiva e social? Quais têm sido as fontes de financiamento das pesquisas nesse campo? Quais temáticas têm sido objeto de pesquisas? Quais as tendências dessa produção? Como e onde são divulgados os novos conhecimentos?

Estas são apenas algumas das muitas perguntas possíveis relacionadas à problemática da produção científica e tecnológica, pela Universidade brasileira, no âmbito da saúde bucal.

$\mathrm{Na}$ presente investigação, apenas algumas dessas importantes questões foram abordadas, com a finalidade de conhecer o impacto do contexto histórico (o período ditatorial e o imediatamente pós-didatura) sobre as opções temáticas dos pesquisadores e a origem das pesquisas relacionadas às políticas de saúde e ao sistema de saúde.

Para isso, tratou-se de identificar e analisar a produção científica na área de odontologia preventiva e social, tanto aquela com origem no âmbito das disciplinas oferecidas na academia, quanto aquela proveniente dos serviços de saúde: a abordagem dessa produção foi feita através de artigos publicados em revistas científicas brasileiras, uma vez que tais artigos podem ser tomados como indicadores expressivos das características dessa produção. Considerou-se relevante conhecer, dentre outros 
aspectos, a origem institucional e profissional dos autores dos artigos publicados, suas preocupações temáticas, características metodológicas e fontes de financiamento das pesquisas das quais resultaram os artigos.

O período estudado, delimitado entre 1986 e 1993, objetivou conhecer as tendências mais recentes dessa produção, e abrangeu o intervalo de tempo localizado entre a I e a II Conferência Nacional de Saúde Bucal, realizadas respectivamente em 10 a 12 de outubro de 1986 e 25 a 27 de setembro de $1993^{83,84}$.

A hipótese da presente investigação foi a seguinte:

No contexto histórico de criação do SUS e afirmação das
proposições da Reforma Sanitária, a produção científica na
área odontológica contemplou as temáticas relacionadas às
políticas de saúde e ao sistema de saúde brasileiro,
contribuindo para a compreensão e superação dos problemas
enfrentados pela sociedade brasileira no âmbito da saúde
bucal coletiva.

Dentre os problemas referidos na hipótese, pode-se destacar, entre outros, o "quadro caótico" da saúde bucal e o próprio conhecimento da "realidade de saúde bucal da população brasileira" (I CNSB) ${ }^{83}$; os relacionados à eficiência e eficácia e ao enfoque curativo e o caráter monopolista e mercantilista da prática, à formação e distribuição dos recursos humanos, à organização do processo de trabalho e à cobertura (VII CNS)"; a "produção de equipamentos e produtos necessários à prática odontológica" (II CNSB) ${ }^{84}$; a “imprescindivel (...) integração da Universidade ao SUDS (...) viabilizada a partir das propostas do setor saúde e levando em conta as 
necessidades e objetivos do sistema unificado" (5० ENATESPO) ${ }^{118}$; e o "reforço de um contexto de dependência econômica e cultural' (VII CNS) ${ }^{85}$. 


\section{OBJETIVOS}

Constituíram objetivos da presente pesquisa identificar e analisar, em artigos publicados em revistas científicas brasileiras, no período 1986-1993:
A) as características e tendências da produção técnico-científica relacionada à área de odontologia preventiva e social no Brasil;
B) a origem institucional dos autores;
C) como os autores se apresentam (titulações etc.);
D) os tipos de pesquisas mais freqüentes nessa área;
E) as opções e tendências metodológicas;
F) as tendências temáticas;
G) as fontes de financiamento das pesquisas que deram origem aos artigos, referidas pelos autores.

Pretende-se também que o conhecimento mais preciso da produção científica da área de odontologia preventiva e social, expressa através de artigos publicados em periódicos, possa fornecer subsídios úteis tanto aos produtores quanto aos usuários dessa produção. Tais subsídios podem, espera-se, auxiliar na reorientação da pesquisa e do ensino nessa área, tanto no âmbito da formação quanto no da educação permanente, sendo portanto de grande valia para a Universidade. 


\section{MATERIAL E MÉTODO}

O material analisado foi constituído por artigos publicados em revistas científicas brasileiras, indexadas ou de reconhecida credibilidade entre profissionais de odontologia e/ou de saúde pública/coletiva.

SALVADOR ${ }^{324}$ (1970) conceitua artigo como produto de "estudos normalmente menos extensos do que aqueles que aparecem em forma de livros", registrando que o artigo "é o meio mais indicado para descrever as investigações em curso e apresentar seus resultados, para propor uma teoria, provocar uma troca de impressões etc.".

Para fins de investigação e de inferência qualitativa da referida produção, admitiu-se que o artigo é um indicador dessa produção técnico-científica.

Assim, cabe reiterar, para esclarecer, que livros, teses, dissertações, documentos e relatórios técnicos variados, ainda que versando sobre conteúdos pertinentes à área, não foram objeto desta pesquisa.

SALVADOR ${ }^{324}$ (1970) assinala que as principais publicações periódicas são o jornal e a revista e conceitua publicações periódicas como "aquelas editadas em fascículos, a intervalos regulares ou irregulares, por tempo ilimitado, com a colaboração de diversos escritores, sob a direção de uma só pessoa ou de várias pessoas, em conjunto ou sucessivamente, que tratam de assuntos diversos, porém dentro dos limites de um programa mais ou menos definido. Sua características principais são a continuidade, ao menos intencional; colaboração, em geral, de várias pessoas; e variedade de conteúdo." Este conceito é suficiente para as finalidades da presente investigação. Pela 
sportunidade, vale recordar, com SALVADOR que a revista é uma publicação periódica "mais recente do que o jornal. $\mathrm{O}$ aparecimento das revistas resultou de uma diferenciação nas exigências do público. Enquanto o jornal se tornava cada vez mais um veículo rápido de notícias, fortalecia-se a necessidade de publicações periódicas menos sujeitas às contingências da rapidez e mais adequadas para refletir os diferentes aspectos da vida cultural, bem como atender a certos interesses específicos. A partir de 1646, começaram a aparecer com certa regularidade, na imprensa francesa e inglesa, notícias de livros, acompanhadas de alguns comentários críticos, e que parecem ter sido os verdadeiros precursores das revistas literárias. O Journal de Sçavants, posteriormente Journal de Savants, fundado em Paris, em 1665, visava à publicação de sumários das principais obras da época, mas, desde o início, publicou também colaborações originais. A primeira publicação inglesa com o título de revista foi a Revista dos Negócios da França e da Europa, fundada em 1704 por Daniel Defoe.”

Sobre as limitações do artigo como um indicador da produção científica cabe a ponderação de VELHO ${ }^{393}$ (1989), para quem "a publicação formal é apenas um dos tipos de comunicação em ciência" e que "outros tipos de conhecimento gerados pela pesquisa podem não chegar até a literatura científica publicada, por uma série de motivos que podem ser ditos sociais: falta de motivação em função do sistema de recompensa vigente; dificuldade de acesso aos periódicos científicos; cláusula de confidencialidade imposta pela instituição etc." Entretanto, prossegue VELHO, “mesmo ignorando essas objeções, para transformar uma contagem de publicações em uma medida de conhecimento gerado, tem que se admitir que todo artigo contém a mesma contribuição 
ao conhecimento - apesar dessa premissa ser muito pouco plausível [pois] a literatura científica não é constituída de artigos de igual qualidade."

Ainda sobre as dificuldades inerentes a empreendimentos analíticos dessa natureza vale também o alerta de PEREIRA e SAES ${ }^{276}$ (1995) quanto às características da avaliação da produção científica e tecnológica de pesquisadores e instituições de pesquisa. Para aqueles autores, esse tipo de produção "não conhece padrões-de-ouro objetivos que permitam comparações definitivas."

O reconhecimento de limites à análise da produção científica num determinado domínio teórico-prático a partir do que é formalmente comunicado através de artigo não deve, contudo, constituir-se em fator inibidor desse tipo de iniciativa. Para ROBINSON ${ }^{304}$ (1989) "os resultados das pesquisas científicas são divulgados através dos canais de comunicação, formais e informais. Embora a comunicação informal seja de grande importância, é através da publicação dos trabalhos que os pesquisadores garantem a propriedade científica e o reconhecimento, de uma forma mais ampla, de seus pares."

MENEGUINI \& FONSECA ${ }^{225}$ (1990) consideram que “(..) é um ponto plenamente aceito que não é possivel medir de maneira absolutamente objetiva o desempenho de um cientista. Indicadores bibliométricos têm, no entanto, sido utilizados como uma aproximação nesse sentido. Em comunidades científicas de países mais avançados existe uma correlação boa entre o prestígio medido por peer-ranking e o desempenho determinado por parâmetros bibliométricos."

Há limitações que não podem ser desconsideradas na abordagem da produção científica pelo indicador artigo publicado. Mas há também que se reconhecer que, 
mesmo com restrições, o artigo publicado constitui material cujo potencial para a investigação científica é desafiador e estimulante.

Assim, considerou-se metodologicamente adequado e lícito tomar o artigo publicado como indicador da produção científica na área de odontologia preventiva e social.

Os procedimentos de localização e busca dos artigos seguiram as recomendações quanto à pesquisa bibliográfica descritas, entre outros, por SALVADOR ${ }^{324}$ (1970), ANDRADE \& NORONHA ${ }^{15}$ (1972), PERRONE ${ }^{280}$ (1972), FERREIRA \& FERRO ${ }^{127}$ (1983), MINAYO ${ }^{234}$ (1992) e GIL ${ }^{150}$ (1994).

Mas esta não é uma pesquisa bibliográfica com o sentido de "estudo recapitulativo de revisão da literatura existente em bibliotecas" referido por SALVADOR $^{324}$ (1970), ou como definido por ANDRADE \& NORONHA ${ }^{15}$ (1972): “o levantamento, a seleção e consequentemente o fichamento dos documentos de interesse para o estudo de um determinado assunto." Não se trata de uma revisão ou "recapitulação", nem do estudo de um mas de vários assuntos.

Também não é uma investigação que se baseia exclusivamente na metodologia da análise de conteúdo, tal como a definiu BARDIN ${ }^{28}$ (1977). Entretanto, ainda que não se refira a um ou alguns documentos, mas a mais de três centenas deles (os artigos científicos), alguns recursos da análise de conteúdo são utilizados para algumas variáveis, como o cálculo de freqüências com o propósito de validação de resultados.

Também se lançou mão de elementos metodológicos da análise de discurso, tal como conceituada por MINAYO ${ }^{234}$ (1992), atentando-se para a produção social do 
sentido (palavras e expressões e suas relações com o processo histórico) e para a formação do significado (todo discurso tem um sujeito; todo sujeito tem uma ideologia).

A propósito, QUIVY \& CAMPENHOUDT ${ }^{298}$ (1992) assinalam que "não existe um método ideal que seja, em si mesmo, superior a todos os outros. Cada um pode prestar os serviços esperados, na condição de ter sido sensatamente escolhido, de ser aplicado sem rigidez e de o investigador ser capaz de medir os seus limites e a sua validade. Em contrapartida, o dispositivo metodológico mais sofisticado é inútil, se o investigador o aplicar sem discernimento crítico ou sem saber claramente o que procura compreender melhor."

Trata-se, neste caso, de um survey analítico, aproximando-se em certo sentido do que $\operatorname{ECO}^{117}(1985)$ chamou de "tese panorâmica", ainda que restrita ao panorama de um breve período de oito anos. 


\subsection{Artigos}

"Artigo" corresponde, neste estudo, a diferentes modalidades de texto. Refere-se às produções aqui classificadas como "artigo original", "artigo de divulgação", "revisão de literatura", "relato de caso clínico", "ensaio", "relato de experiência", ou "estudo de caso".

Não foram objeto de apreciação os textos conhecidos como "resenha", por se referirem, de modo geral, a alguma publicação não periódica. Evidentemente, publicações não periódicas (livros, manuais e outras) também não foram consideradas.

A seguir, são conceituados os diferentes tipos de textos examinados, acrescidos, quando pertinente, das definições empregadas por Ciência e Cultura ${ }^{82}$, a revista da Sociedade Brasileira para o Progresso da Ciência (SBPC):

- "Artigo original": texto cujo conteúdo refere-se a conhecimento original, produzido tanto no campo da denominada pesquisa básica quanto no da pesquisa aplicada. Ciência e Cultura denomina esse tipo de texto como "Artigo de Pesquisa", definindo-o como aquele que contém "resultados novos e consolidados de pesquisa experimental ou teórica, apresentados de maneira abrangente e discutidos nas suas implicações. Devem ser precedidos de uma introdução que situe a contribuição contida no artigo em contexto mais amplo, inteligível para não especialistas (...)”.

- "Artigo de divulgação": texto cujas caracteristicas de conteúdo e, sobretudo, forma, está dirigido a público não especializado ou leigo e cuja finalidade é a divulgação de um determinado conhecimento, originariamente 
produzido e divulgado em um artigo original. ANDRADE \& NORONHA ${ }^{15}$ (1972) assinalam que esse tipo de artigo "não cabe em revistas especializadas. Destina-se a público leigo.” Ainda assim, essa categoria foi mantida na presente classificação uma vez que revistas científicas menos exigentes abrem suas páginas para tais artigos.

- "Revisão de literatura": texto cuja finalidade principal é a verificação e relato, de forma ordenada (cronologicamente ou outra ordenação estabelecida pelo autor da revisão), do que foi publicado (livros e revistas científicas, por exemplo) sobre um determinado assunto ou tema, num determinado período de tempo. Para Ciência e Cultura são "textos reunindo os principais fatos e idéias de um determinado domínio de pesquisa, estabelecendo relações entre eles e evidenciando a estrutura conceitual própria ao domínio (...)".

• "Relato de caso clínico": texto cuja finalidade básica é a descrição de um caso clínico, cujas características apresentem singularidades tais que justifiquem sua divulgação no meio acadêmico.

• "Ensaio": nesta investigação, foi classificado como ensaio o texto acadêmico cujas características formais o diferenciam, basicamente, do artigo original e da revisão de literatura. Seu conteúdo o diferencia também do artigo de divulgação, uma vez que é dirigido, especialmente mas não exclusivamente, ao leitor especializado. Para a SBPC ensaio é um 'texto contendo contribuição interpretativa original de dados e conceitos de 
domínio público." SALVADOR ${ }^{324}$ (1970) comenta que o ensaio, originariamente, "era um comentário breve, informal e subjetivo, não concludente. A isto denomina-se hoje, no Brasil, de crônica. O ensaio passou a ser sinônimo de um estudo bem desenvolvido, formal, discursivo e concludente. Consiste, pois, numa exposição lógica e reflexiva, segundo uma estrutura metódica, que inclui introdução, corpo de discussão e conclusão, redigida em linguagem austera, embora possa aspirar a certa elegância literária, desde que não prejudique a compreensão exata das idéias, sobre assuntos sérios, embora ainda pouco explorados, acerca dos quais expende um juízo ou conclusão. Contudo, guarda ainda algo de seu significado primitivo, já que não se constitui num estudo definitivo. É, de fato, um ensaio, ou seja, uma primeira tentativa de sistematização de idéias ou de fatos sobre assuntos pouco explorados [revelando] um enfoque pessoal [e dispensando] o aparato crítico exterior, como a abundância de citações e apresentação de grande quantidade de fontes bibliográficas. Não prescinde, porém, de um fino sentido de rigor e uma firme coerência expositiva."

- "Relato de experiência": texto cuja finalidade principal é relatar uma experiência desenvolvida em tempo e lugar definidos. $\mathrm{O}$ relato de experiência não contém, necessariamente, resultados, análises ou generalizações. Simplesmente, descreve uma experiência.

- "Estudo de caso": texto que se refere a uma experiência desenvolvida em tempo e lugar definido. O estudo de caso contém, necessariamente, 
resultados e análises e pode trazer ainda indicações de possiveis generalizações e suas limitações. Não se trata, o estudo de caso, de simples descrição de uma experiência.

Ainda sobre os artigos: a análise realizada abrangeu o "título" e a "metodologia empregada".

O título foi analisado quanto sua adequação à finalidade de auxiliar o leitor a identificar o objeto do artigo, bem como sua coerência com o conteúdo do texto.

FERRAZ ${ }^{126}$ (1971) sustenta que o título deve "exprimir com exatidão e brevidade o assunto tratado. Deve estar distante dos dois extremos: nem genérico demais, nem tão específico a ponto do autor pretender abranger todos os aspectos tratados no trabalho. Um mau título levará os serviços de bibliografia a indexá-lo sob cabeçalhos errados, não logrando o trabalho a divulgação almejada (...) Cuidados especiais devem ser tomados com títulos que possam ter sentido ambiguo. Se for necessário dar maior amplitude ao título, é preferivel usar subtítulo explicativo."

A questão da localização do objeto no tempo e no espaço não foi considerada para avaliar a adequação do título, uma vez que raramente isso ocorreu.

É pertinente, a propósito, a seguinte consideração. Essa característica (omissão de tempo e lugar) pode ser atribuída tanto aos autores que, de modo geral, não atribuem ao título essa função, quanto à orientação dos conselhos editoriais das publicações, alguns dos quais recomendam explicitamente aos autores que não procedam dessa forma. Pretendem esses editores "títulos concisos" ${ }^{82}$, à maneira de jornais e revistas de divulgação. Resulta evidente o prejuízo que essa recomendação significa em termos de 
informação. Em casos de busca, por exemplo, com o título omitindo informações sobre tempo e lugar, o leitor terá que buscar esses dados no resumo, para confirmar seu interesse por determinado artigo. Cabe comentar o que tal procedimento significa em termos de tempo. Há casos em que o artigo terá de ser necessariamente lido, às vezes mobilizando recursos de comutação bibliográfica, para, ao final, o pesquisador descobrir que o tempo e/ou o lugar a que se refere o artigo em questão não são pertinentes à investigação em que ele está envolvido. Pode-se argumentar, em sentido contrário, que a própria data de publicação é um indicador do tempo. Cabe assinalar, então que indica mas não define com precisão. Se informações precisas podem ser fornecidas ao leitor, por que não fornecê-las?

Quanto à metodologia empregada, verificou-se as características relacionadas ao como e com quais recursos o conhecimento foi produzido e/ou está sendo divulgado. Para fins de quantificação, a metodologia foi classificada em "adequada" ou “inadequada". Considerou-se ADEQUADA quando, entre outras características, a metodologia apresentava-se coerente com os propósitos do artigo, os instrumentos eram pertinentes e o tratamento dado ao material compatível com as possibilidades científicas atuais (exploração, apresentação e tratamento estatístico suficiente dos dados, por exemplo). A condição INADEQUADA foi empregada quando tais características não estavam presentes.

É preciso reconhecer a subjetividade envolvida em julgamentos desse tipo. O que se pretendeu com tal recurso metodológico não foi realizar uma abordagem quantitativa utilizando indicadores conhecidos, ou que tenham sido desenvolvidos e testados anteriormente em pesquisa(s) semelhante. A presente classificação teve a finalidade de 
permitir uma aproximação à problemática da metodologia em pesquisas na área de OPS. Em virtude das características mais gerais desta investigação, em que vários outros aspectos também estão em foco, não se pretendeu mais do que esse referencial genérico para as questões relacionadas à metodologia.

Buscou-se, também, identificar os artigos que resultaram de pesquisas desenvolvidas no âmbito de cursos de pós-graduação e, portanto, estavam relacionados a dissertações ou teses. 


\subsection{Periódicos}

Foram examinados os seguintes periódicos:

- Arquivos do Centro de Estudos do Curso de Odontologia da Universidade Federal de Minas Gerais;

- Brazilian Dental Journal;

- Cadernos de Saúde Pública;

- Ciência \& Cultura;

- Enciclopédia Brasileira de Odontologia;

- Estomatologia \& Cultura;

- Odonto Ciência;

- Odontólogo Moderno;

- Revista Brasileira de Odontologia;

- Revista Brasileira de Saúde Escolar;

- Revista da Associação Paulista de Cirurgiões-Dentistas;

- Revista da Faculdade de Odontologia da Universidade Federal da Bahia;

- Revista da Faculdade de Odontologia de Porto Alegre;

- Revista de Odontologia da Universidade Estadual Paulista Julio de Mesquita Filho;

- Revista de Odontologia da Universidade de São Paulo;

- Revista de Saúde Pública;

- Revista Odontológica do Brasil Central;

- Revista Paulista de Odontologia;

- RGO;

- Saúde em Debate. 
Embora esses 20 (vinte) periódicos não correspondam à totalidade das revistas cientificas brasileiras da área de odontologia e/ou de saúde pública/coletiva, considerouse que expressam com fidelidade o que de mais significativo é publicado nessas áreas no Brasil. Assim, podem, para as finalidades da presente investigação, serem tomados como representativos do que é publicado no País.

LOURO FILHO ${ }^{195}$ (1982) utilizou, no trabalho Avaliação \& Perspectivas 1982 - Odontologia, realizado à pedido do Conselho Nacional de Desenvolvimento Científico e Tecnológico ( $\mathrm{CNPq}$ ), uma amostra contendo nove periódicos odontológicos brasileiros:

- Revista Paulista de Odontologia;

- Revista Gaúcha de Odontologia;

- Odontólogo Moderno;

- Arquivo do Centro de Estudos do Curso de Odontologia da UFMG;

- ARS Cvrandi em Odontologia;

- Revista da Associação Paulista de Cirurgiões-Dentistas;

- Revista da Faculdade de Farmácia e Odontologia de Ribeirão Preto;

- Revista da Faculdade de Odontologia da USP; e,

- Revista Brasileira de Odontologia.

Com exceção de $A R S$ Cvrandi em Odontologia cuja publicação cessou antes de 1986, todas as demais relacionadas por LOURO FILHO foram incluídas na presente investigação. 
Quanto à Revista da Faculdade de Farmácia e Odontologia de Ribeirão Preto, passou a constituir, a partir de 1987, juntamente com a Revista da Faculdade de Odontologia da USP e com Estomatologia \& Cultura, uma nova publicação denominada Revista de Odontologia da USP.

Três novos periódicos surgiram no período do estudo e, pela sua importância para o objeto desta pesquisa, foram incluídos: o Brazilian Dental Journal (1990), a Revista Brasileira de Saúde Escolar (1990) e a Revista Odontológica do Brasil Central (1991).

Ao contrário, a Enciclopédia Brasileira de Odontologia, cuja publicação se iniciara em 1983, teve sua série interrompida em 1988. A Enciclopédia não chegou ao sétimo volume.

A propósito, MADEIRA \& CARVALHO ${ }^{200}$ (1988) citam SEVERINO ("é impressionante o número de periódicos cuja publicação foi interrompida") e assinalam que a decisão de iniciar a publicação de uma revista científica é, muitas vezes, "tomada no calor de um entusiasmo passageiro, com pressa e sem muito planejamento e previsão orçamentária. $\mathrm{O}$ resultado será sempre uma circulação irregular, que poderá levar à interrupção definitiva da publicação." $\mathrm{Na}$ referida pesquisa, abrangendo periódicos brasileiros de odontologia no período de 1920 a 1987, os autores concluem que dos 149 títulos editados no período considerado "apenas 40 (26,8\%) encontram-se [1988] em circulação, sob a denominação original ou sob uma nova denominação. $109(73,2 \%)$ desapareceram!". 
Ciência \& Cultura foi considerada por ser a revista oficial da Sociedade Brasileira para o Progresso da Ciência (SBPC). A importância dessa entidade no meio científico brasileiro é notória e o seu periódico não poderia ser ignorado nesta investigação.

Dentre as revistas dirigidas ao campo da saúde pública/coletiva, optou-se pela inclusão das três publicações de abrangência nacional, de maior circulação, credibilidade e tradição de publicar autores originários das diferentes regiões brasileiras. Dessas três, Saúde em Debate, órgão oficial do Centro Brasileiro de Estudos de Saúde (CEBES), não está indexada mas é, reconhecidamente, uma publicação de grande penetração nessa área no Brasil, haja vista a alta freqüência de citações de artigos nela publicados observada na literatura desse campo. A Revista de Saúde Pública, publicada sob responsabilidade da Faculdade de Saúde Pública da Universidade de São Paulo, está indexada nas bases de dados MEDLINE, CAB-Health, EMBASE, Health Plan, Human Nutrition, Life Science Collection, Popline, LILACS, AdSaúde e DOCPAL e também, além de outras 11, nas seguintes bibliografias impressas: Abstracts on Hygiene and Communicable Diseases, Current Contents/Social \& Behavioral Science, Index Medicus e Social Science Citation Index. Cadernos de Saúde Pública, uma publicação da Editora FIOCRUZ, sob responsabilidade da Escola Nacional de Saúde Pública, da Fundação Oswaldo Cruz, do Ministério da Saúde, está indexada na base de dados LILACS (Literatura Latino-Americana e do Caribe em Ciências da Saúde) e, além de outras 8, nas seguintes bibliografias impressas: Sociological Abstracts, Social Planning/Policy \& Development, Index Medicus Latino-Americano, Abstracts on Hygiene and Communicable Diseases, Tropical Disease Bulletin, Red Panamericana de Informacion y 
Documentacion en Ingenería Sanitária y Ciencias del Ambiente. Quanto à Revista Brasileira de Saúde Escolar (RBSE) foi considerada indispensável uma vez que se ocupa de um grupo populacional (os escolares) tradicionalmente envolvido com as ações desenvolvidas no âmbito da odontologia preventiva e social. A RBSE está indexada nas bases de dados LILACS, AdSaúde e USP-Dedalus. 


\subsection{Bibliotecas}

Para desenvolvimento do trabalho de campo foram consultados os acervos e/ou utilizados os serviços das bibliotecas das seguintes instituições:

No município de São Paulo:

- Faculdade de Saúde Pública da Universidade de São Paulo;

- Faculdade de Odontologia da Universidade de São Paulo;

- Universidade de Santo Amaro;

- Universidade Paulista;

- Universidade Camilo Castelo Branco;

- Associação Paulista de Cirurgiões-Dentistas;

- Editora do Jornal Brasileiro de Medicina.

Ca No município de São Bernardo do Campo:

- Universidade Metodista.

$\square$ No município de Mogi das Cruzes:

- Universidade de Mogi das Cruzes.

No município de São José dos Campos:

- Universidade Estadual Paulista Julio de Mesquita Filho;

- Universidade do Vale do Paraíba.

$\square$ No município de Bragança Paulista:

- Universidade São Francisco.

$\square$ No município de Campinas:

- Pontificia Universidade Católica de Campinas.

No município de Piracicaba: 
- Faculdade de Odontologia da Universidade Estadual de Campinas.

É de se esperar, em pesquisas como a presente investigação, a necessidade de se consultar o acervo de diferentes bibliotecas. Entretanto, dada a especificidade dos periódicos de interesse, cabe menção ao grande número de bibliotecas visitadas. $\grave{A}$ primeira vista, esse número pode parecer desnecessário, exagerado. Tal fato é conseqüência, entretanto, da precariedade de boa parte das coleções de periódicos dessas bibliotecas, desfalcadas de muitos fascículos. Aliás, foram raras as coleções que se apresentaram completas. Houve fascículos que só foram obtidos mediante consulta aos editores, uma vez que seus exemplares não foram encontrados em nenhuma das bibliotecas anteriormente relacionadas. Apenas para ilustrar, tal foi o caso do fascículo 4 (julho/agosto), volume 49 (1992), da Revista Brasileira de Odontologia (RBO) e do fascículo 2 (junho), volume 2 (1992), da Revista Odontológica do Brasil Central (ROBRAC). Igualmente, vários fascículos do Odontólogo Moderno $(\mathrm{OM})$ só puderam ser analisados graças à gentileza da empresa representante da editora da revista em São Paulo, que permitiu consulta à sua coleção particular.

Embora o referido fascículo da RBO conste oficialmente do acervo da biblioteca da UNESP de São José dos Campos, a verificação e consulta ao exemplar não pode ser realizada pois, no dia da visita, aquela biblioteca estava em reformas.

É de se destacar que, excetuando-se a ainda jovem ROBRAC, lançada em 1991, tais periódicos não são de circulação limitada, o que justiticaria, de certa forma, as dificuldades em localizá-los. Ao contrário, RBO e OM são periódicos com tiragem expressiva que circulam regularmente e têm grande penetração e credibilidade no meio 
odontológico. A RBO foi fundada em 1943 e o Odontólogo Moderno circula desde 1973. Bastante conhecidos, parece não haver justificativas para as ausências de seus fascículos nas coleções de bibliotecas vinculadas às mais importantes instituições universitárias do país, com atuação na área odontológica.

Deve-se assinalar ainda que, além das bibliotecas visitadas, foram acionados, para os fascículos mencionados, sistemas eletrônicos de busca em diferentes bases nacionais de dados, sempre com resultados negativos.

Os exemplos expostos indicam problemas em duas direções.

Por um lado, expressam os obstáculos de toda ordem que editores têm de enfrentar para a produção regular e a adequada distribuição das suas publicações. Tais empecilhos atingem até mesmo revistas consagradas do ponto de vista editorial. $\mathrm{O}$ fato de um periódico como RBO ter certos fascículos ausentes nas coleções de tantas e importantes bibliotecas sugere que tais ausências não podem ser atribuídas às dificuldades das bibliotecas mas a problemas relacionados à sua produção e distribuição.

De outra parte, deve-se reconhecer que não são pequenas as dificuldades encontradas pelas bibliotecas para manter seus respectivos acervos; dificuldades que vão, por exemplo, da falta de funcionários ao roubo. $\mathrm{O}$ furto não é estranho às bibliotecas em todo o mundo. Em nosso país, entretanto, essa prática passa muito dos limites suportáveis. Os maus tratos aos acervos, decorrente em parte da falta de estímulo para que as pessoas freqüentem bibliotecas e aprendam a compartilhar e valorizar bens culturais, contribui para o aumento dos roubos e a deterioração das bibliotecas. Superar tais problemas requer investimentos em pessoal e em segurança, além obviamente da 
valorização do acervo propriamente dito, também pelos dirigentes das instituições. Isto é, exige o reconhecimento, em cada instituição, de que sem biblioteca de qualidade não se deve esperar qualidade no ensino e na pesquisa ali produzidos.

\subsection{A Área de Odontologia Preventiva e Social}

Uma categoria central ao desenvolvimento da presente pesquisa é o que se convencionou denominar Área de Odontologia Preventiva e Social. Constitui pois, exigência metodológica elementar expressar o entendimento que, neste estudo, está sendo adotado para "Área de Odontologia Preventiva e Social". Tal entendimento pode não coincidir com outros, utilizados no âmbito da categoria profissional dos odontologistas, ou na Universidade, ou nos serviços de saúde, em virtude de serem os termos "preventivo" e "social" altamente polêmicos e passíveis de diferentes entendimentos e significados, conforme NARVAI ${ }^{251}$ (1993).

Apenas para ilustrar, veja-se as considerações de PINTO 292 (1989) sobre o assunto:

“(...) quando a odontologia efetivamente transformar-se em uma ciência social e preventiva, as disciplinas correspondentes deixarão de existir, uma vez que seus conteúdos estarão embutidos em cada passo do currículo e do fazer diário da profissão... A separação entre as áreas preventiva e social só se justifica por motivos didáticos não devendo existir na prática, pois ambas são componentes de um mesmo corpo de conhecimentos no qual cabe à primeira identificar as origens dos problemas de saúde bucal e apresentar os métodos capazes de impedir sua 
ocorrência, enquanto à odontologia social compete, ademais de reunir condições propícias para o uso dos métodos preventivos, estruturar o sistema de prestação de serviços à comunidade, incluindo a obtenção dos insumos necessários (recursos humanos, físicos e financeiros) e a organização final do trabalho."

No presente, o próprio Conselho Federal de Odontologia não mais adota a expressão "Odontologia Preventiva e Social" para caracterizar uma das especialidades odontológicas. Substituiu-a por "Odontologia em Saúde Coletiva". Concorreram muitas razões para essa substituição, amplamente debatidas na I ANEO - Assembléia Nacional de Especialidades Odontológicas (Rio de Janeiro, 17-20/4/1992), convocada pelo Conselho Federal de Odontologia para "regulamentar a questão das especialidades odontológicas e dos cursos destinados à formação de especialistas".

Vale lembrar, nesse sentido, conforme referido por NARVAI ${ }^{251}$, o documento apresentado à I ANEO por professores da área de odontologia preventiva e saúde pública do Departamento de Prática de Saúde Pública da Faculdade de Saúde Pública, Universidade de São Paulo, onde os docentes afirmam:

“A Resolução CFO-167/90e, já havia alterado (art. $3^{\circ}$ ) 'a denominação da especialidade de Odontologia Preventiva e Social para Odontologia Social'.

"O adjetivo preventiva foi eliminado da denominação de modo muito oportuno, tendo em vista as inúmeras manifestações nesse sentido que, de

\footnotetext{
e) CONSELHO Federal de Odontologia. Resolução CFO-167/90. Rio de Janeiro, 09 de novembro de 1990. Publicada no Diário Oficial da União. em 27/12/1990 - Parte I. página 25.475.
} 
longa data, vinham ocorrendo em congressos, jornadas científicas e encontros que reuniam especialistas da área e, também colegas de outras especialidades. Atualmente, não há razões para pensar prevenção como uma especialidade odontológica, uma vez que conhecimentos, atitudes e práticas preventivas devem perpassar todo o campo de atividades odontológicas. Há consenso sobre isso na comunidade odontológica.

"Todavia, o adjetivo social foi, inexplicavelmente, mantido na denominação da especialidade contrariando a expectativa da maioria dos cirurgiões-dentistas que atuam nesse campo. Argumenta-se, basicamente, que não é possível conceber práticas odontológicas que não sejam sociais. O qualificativo social não definiria portanto rigorosamente nada, tendo o grande inconveniente de, por causa da conotação que o termo social adquiriu no Brasil nos últimos anos, propiciar associações de idéias com algo precário, sem qualidade, relativo e dirigido a pobres. Uma espécie de odontologia de segunda ou terceira classe voltada aos problemas de subcidadãos ou, como querem alguns, uma odontologia para 'carentes'."

Em resumo, muitas são as concepções de odontologia social. A exemplo do próprio substantivo "odontologia", cuja palavra não consegue constituir-se em termo (no sentido de expressar uma idéia comum a diferentes interlocutores) também o adjetivo "social" é uma palavra que comporta distintos significados.

Não é propósito desta investigação tratar da questão desses muitos e distintos significados. As considerações anteriores têm o propósito de esclarecer que ao 
pesquisador não são desconhecidas as polêmicas que cercam a expressão "odontologia preventiva e social", a qual, conforme assinalado anteriormente, constitui categoria central nesta pesquisa.

Há, todavia, que caracterizar essa Área.

Por outro lado, através da Resolução CFO-185/93, de 26/4/93, o Conselho Federal de Odontologia 89 conceitua "Odontologia em Saúde Coletiva" como:

"a especialidade que tem como objetivo o estudo dos fenômenos que interferem na saúde bucal coletiva, por meio de análise, organização, planejamento, execução e avaliação de serviços, projetos ou programas de saúde bucal, dirigidos a grupos populacionais, com ênfase nos aspectos preventivos."

Ao estabelecer as áreas de competência da "Odontologia em Saúde Coletiva" a Resolução CFO-185/93 elenca as seguintes:

“a) análise sócio-epidemiológica dos problemas de saúde bucal da comunidade;

“b) elaboração e execução de projetos, programas e/ou sistemas de ação coletiva ou de saúde pública visando à promoção, ao restabelecimento e ao controle da saúde bucal;

“c) participação, em nível administrativo e operacional de equipe multiprofissional, por intermédio de: (1) organização de serviços; (2) gerenciamento em diferentes setores e níveis de administração em 
saúde pública; (3) vigilância sanitária; (4) controle de doenças; (5) educação em saúde pública;

“d) identificação e prevenção das doenças bucais oriundas exclusivamente da atividade laboral."

Esta caracterização da "odontologia em saúde coletiva", sucedânea da "odontologia preventiva e social" no âmbito do Conselho Federal de Odontologia, foi adotada como definidora do que, na presente investigação, se está denominando "Área de Odontologia Preventiva e Social". Considerou-se portanto que, para os propósitos desta pesquisa, ambas as expressões podem ser admitidas como referentes de um mesmo objeto. A opção pelo emprego da expressão Odontologia Preventiva e Social neste texto, produzido num momento histórico em que a denominação oficial é Odontologia em Saúde Coletiva, se justifica uma vez que a pesquisa se ocupa de um período histórico em que vigorava a expressão Odontologia Preventiva e Social. 


\subsection{Procedimentos}

O processo de trabalho de investigação foi caracterizado por diferentes momentos cuja seqüência é apresentada a seguir. Tais momentos não se constituíram, entretanto, em etapas com rígidas conexões entre si. Ao contrário, freqüentemente, dentro de limites impostos pela organização racional do trabalho, esses momentos se alternaram com idas e vindas necessárias à construção analítica:

\subsubsection{Primeiro Momento}

\section{Elaboração, pré-teste e definição da ficha:}

- Estabelecido o tipo de dado necessário ao empreendimento de análise e, definido onde buscá-lo, tratou-se de construir um instrumento adequado a essa finalidade. Uma primeira versão do instrumento foi montada e testada em seis artigos de diferentes periódicos. Tal teste permitiu detectar omissões, imprecisões e inadequações nessa primeira versão do instrumento, levando à necessidade de modificá-lo. Feitos os acertos o instrumento foi novamente testado em três artigos e considerado adequado. Este instrumento é apresentado no Anexo 1.

- Definido o instrumento de coleta de dados e, portanto, as variáveis de estudo (nome do periódico; ano de publicação do periódico; título do artigo; relação com tese/dissertação; titulação do primeiro, segundo e terceiro autores; sexo do primeiro, segundo e terceiro autores; origem institucional do primeiro, segundo e terceiro autores; origem geográfica do primeiro autor; fonte de financiamento da pesquisa; domínio temático a que se vincula o artigo; tema; tipo de pesquisa; tipo de artigo; e, 
metodologia), prosseguiu-se, passando à montagem de um banco de dados contendo as respectivas variáveis. Referido banco de dados foi construido utilizando-se o programa EPED do pacote denominado EPI-INFO, versão 5.01, desenvolvido pelo Centro de Controle de Doenças (Atlanta, EUA) para a Organização Mundial da Saúde. Quinze fichas de testes foram inseridas no banco de dados para testá-lo, tendo sido aprovado.

\subsubsection{Segundo Momento}

\section{Trabalho de campo:}

- Definido o instrumento, montado e testado o banco de dados, deu-se início ao trabalho de campo. Este consistiu em localizar as coleções de periódicos em diferentes bibliotecas e proceder à identificação, através da leitura do sumário de cada fascículo, dos artigos relativos à área de OPS. Havendo dúvida quanto à pertinência de um determinado artigo à área de interesse, este era objeto de leitura do tipo leitura de reconhecimento ou prévia, conforme a indicação de SALVADOR 324 (1970), para esclarecimento. Identificado o(s) artigo(s) de interesse, este era lido, analisado e devidamente fichado. Para isto, utilizava-se o instrumento desenvolvido para essa finalidade, o qual comporta tanto os registros clássicos necessários à produção da referência bibliográfica quanto os relativos às variáveis de estudo. Com base nos resultados dos pré-testes, cada variável foi codificada de modo a facilitar o processamento estatístico, com exceção da variável relativa ao tema predominante. As informações relevantes de cada artigo analisado eram registradas no verso do instrumento. A destacar nesta fase, as dificuldades para obtenção de coleções completas dos periódicos, conforme referido no item 4.3. 


\subsubsection{Terceiro Momento}

\section{Apuração dos dados:}

- Na medida em que o trabalho de campo foi sendo desenvolvido, foram sendo digitados os dados. Dessa maneira, o final do trabalho de campo praticamente coincidiu com o encerramento da digitação dos dados, passando-se em seguida à obtenção das principais tabelas e aos exercícios de cruzamento de dados, de modo a identificar os mais significativos.

\subsubsection{Quarto Momento}

Nesta fase, dispondo-se das tabelas, procedeu-se à sua análise detalhada, dandose início ao processo de redação preliminar do texto. Procedeu-se à incorporação dos registros e informações disponiveis na ficha relativa a cada artigo, de modo a ir estruturando e compondo uma visão global do que foi a produção científica da área de OPS no período em estudo.

\subsubsection{Quinto Momento}

Redação das versões preliminar e final da Tese. 


\section{RESULTADOS E DISCUSSÃO}

Foram analisados 386 (trezentos e oitenta e seis) artigos, publicados em 19 (dezenove) periódicos, registrando-se pelo menos 866 (oitocentos e sessenta e seis) autorias. Este número se refere a um mínimo ("pelo menos"), uma vez que se leva em conta apenas o registro dos três primeiros autores. Não são, obviamente, 866 autores, uma vez que vários autores participaram da autoria de muitos artigos.

Deve ser ressaltada, conforme os argumentos apresentados a seguir, a modéstia quantitativa dessa produção.

Admitindo-se pelo menos dois docentes vinculados às disciplinas de OPS nos 86 cursos referidos no Capitulo 1, ter-se-ia 172 docentes. Então, apenas nesse segmento dos produtores vinculados às instituições formadoras de recursos humanos, seriam 172 autores potenciais. Ainda que com a ressalva de que se refere à produção média dos cursos de pós-graduação em odontologia, nas diferentes áreas de concentração, se aceitarmos o parâmetro referido por VIANNA ${ }^{400}$ (1987) de publicação em média de 0,45 publicação por ano (publicação inclui cursos, livros, artigos etc.), seriam, apenas nesse segmento, 620 artigos publicados em 8 anos. Considerando que parte dessa produção pode ter sido publicada em periódicos não incluídos na amostra utilizada nesta investigação (periódicos estrangeiros, revistas científicas dirigidas a segmentos especializados e, em menor parte, livros e cursos), pode-se admitir que 620 é um número superestimado. Entretanto, considerando a participação de autores com outras vinculações, não seria exagero esperar cerca de 800 artigos publicados no período considerado para estudo. 
Assim, observa-se que a produção efetiva foi inferior a $50 \%$ do potencial da área. Deve-se considerar, para esta afirmativa, que VIANNA caracterizou como "baixa" a produção de 0,45 publicação/autor/ano, referindo centros de pós-graduação com desempenho de 1 e até mesmo 2 publicações/autor/ano.

Pode-se afirmar em conseqüência que, seguramente, a produção na área de OPS está abaixo da média obtida para o conjunto das áreas, a qual $(0,45)$ já é tida como "baixa".

A apresentação dos resultados é feita nas tabelas de número 1 a 14 e a discussão está estruturada em tópicos como segue:

\section{1. Os periódicos}

Os periódicos apresentaram diferenças marcantes quanto à opção de publicar artigos relativos à odontologia preventiva e social. Observa-se na Tabela 1 que a $R G O$ liderou com 106 artigos (27,5\%), seguida pela Revista da Associação Paulista de Cirurgiões-Dentistas (APCD) com 53 artigos (13,7\%). Dentre os periódicos selecionados para consulta, Ciência e Cultura não publicou nenhum artigo da área de OPS.

Pode-se notar, ainda na Tabela 1 , que a maior porcentagem $(17,1 \%)$ dos artigos foi publicada em 1992. O ano com menor número de artigos de OPS publicados foi 1988: os 30 artigos representam 7,8\%. Tal diferença, entretanto, não parece ter qualquer significado, podendo ser atribuída ao acaso, uma vez que a série histórica apresenta 
distribuição relativamente homogênea, não se observando qualquer tendência para mais ou para menos ao longo dos anos.

Quanto aos periódicos, artigos de OPS se distribuem com certa homogeneidade no período. Entretanto, Saúde em Debate destoa em 1986, devido a uma edição especial sobre "Odontologia Comunitária". 
ELA 1. Artigos sobre Odontologia Preventiva e Social em periódicos brasileiros selecionados, no periodo 1986-1993 segundo o ano de publicação.

\begin{tabular}{|c|c|c|c|c|c|c|c|c|c|c|}
\hline \multirow[t]{2}{*}{ ME DO PERIÓDICO } & \multicolumn{8}{|c|}{ ANO } & \multicolumn{2}{|c|}{ TOTAL } \\
\hline & 86 & 87 & 88 & 89 & 90 & 91 & 92 & 93 & $\mathrm{~N}$ & $\%$ \\
\hline $\begin{array}{l}\text { zilian Dental Journal } \\
\text { ernos de Saúde Pública }\end{array}$ & $\star$ & $\star$ & $\star$ & $\star$ & - & 1 & - & 3 & 4 & 1,0 \\
\hline \multirow{2}{*}{$\begin{array}{l}\text { ernos de Saúde Pública } \\
\text { cia e Cultura }\end{array}$} & 1 & 1 & - & - & 1 & - & - & - & 3 & 0,8 \\
\hline & - & - & - & - & - & - & - & - & - & - \\
\hline \multirow{2}{*}{$\begin{array}{l}\text { iclopédia Brasileira de Odontologia } \\
\text { intólogo Moderno }\end{array}$} & - & 5 & 4 & $\star$ & $\star$ & $\star$ & $\star$ & $\star$ & 9 & 2,3 \\
\hline & 8 & 6 & 5 & 5 & 6 & - & 4 & 8 & 42 & 10,9 \\
\hline Into Ciência & 3 & 2 & 1 & - & - & - & 2 & 1 & 9 & 2,3 \\
\hline \multirow{3}{*}{$\begin{array}{l}\text { ista Brasileira de Odontologia } \\
\text { ista Brasileira de Saúde Escolar } \\
\text { ista da } \mathrm{APCD}^{(a)}\end{array}$} & 2 & 5 & 2 & 2 & 4 & 3 & 4 & 7 & 29 & 7,5 \\
\hline & $\star$ & $\star$ & $\star$ & $\star$ & - & $\star$ & 3 & - & 3 & 0,8 \\
\hline & 6 & 4 & 3 & 8 & 5 & 9 & 12 & 6 & 53 & 13,7 \\
\hline da FO da UFBA ${ }^{(b)}$ & 2 & 4 & - & 2 & - & 3 & - & 3 & 14 & 3,6 \\
\hline da FO de Porto Alegre & - & - & - & 1 & 1 & 1 & 4 & - & 7 & 1,8 \\
\hline ista de Odontologia da UNESP ${ }^{(c)}$ & - & - & 3 & 4 & 1 & - & 1 & 5 & 14 & 3,6 \\
\hline \multirow{2}{*}{$\begin{array}{l}\text { sta de Odontologia da USP } \\
\text { sta de Saúde Pública }\end{array}$} & - & - & 3 & 3 & 6 & - & 4 & 1 & 17 & 4,4 \\
\hline & - & - & 1 & 1 & 2 & - & 1 & 1 & 6 & 1,6 \\
\hline ) & 16 & 12 & 7 & 11 & 8 & 13 & 21 & 18 & 106 & 27,5 \\
\hline \multirow{4}{*}{$\begin{array}{l}\text { sta Odontológica do Brasil Central } \\
\text { sta Paulista de Odontologia } \\
\text { le em Debate } \\
\text { do Centro de Est. CO da UFMG }\end{array}$} & $\star$ & $\star$ & $\star$ & $\star$ & $\star$ & - & 2 & 2 & 4 & 1,0 \\
\hline & 3 & 5 & - & 3 & 5 & 6 & 1 & 5 & 28 & 7,3 \\
\hline & 11 & - & 1 & 1 & 2 & 4 & 6 & 3 & 28 & 7,3 \\
\hline & 1 & 1 & - & 2 & 1 & - & 1 & - & 6 & 1,6 \\
\hline $\begin{array}{l}\text { do Centro de Est. CO da UFMG } \\
\text { matologia \& Cultura }\end{array}$ & 4 & $\star$ & $\star$ & $\star$ & $\star$ & $\star$ & $\star$ & $\star$ & 4 & 1,0 \\
\hline \multirow[t]{2}{*}{ 'AL } & 57 & 45 & 30 & 43 & 42 & 40 & 66 & 63 & 386 & 100,0 \\
\hline & 14,8 & 11,6 & 7,8 & 11,1 & 10,9 & 10,4 & 17,1 & 16,3 & 100,0 & \\
\hline
\end{tabular}

PCD = Associação Paulista de Cirurgiões-Dentistas; (b) Rev. da FO = Revista da Faculdade de Odontologia; NESP = Universidade Estadual Paulista Julio de Mesquita Filho; (d) USP = Universidade de São Paulo;

rquivos do Centro de Estudos do Curso de Odontologia da Universidade Federal de Minas Gerais; ( $\star$ ) Não circulou. 


\section{2. Os autores}

As autorias dos artigos foram, por ampla maioria, de profissionais vinculados a instituições universitárias públicas. De um total de 866 autores, 658 (76,0\%) apresentaram essa característica. São 59 as autorias vinculadas a instituições universitárias privadas, correspondendo a $6,9 \%$ do total. Apenas 95 autores $(10,9 \%)$ registraram vínculo institucional com serviços de saúde, dos quais $81(9,3 \%)$ com serviços públicos e $14(1,6 \%)$ com serviços privados. Em 4,7\% dos casos (41) não foi possível identificar a origem institucional das autorias (Tabela 2).

Tabela 2. Autores de artigos sobre Odontologia Preventiva e Social em periódicos brasileiros selecionados, no período 1986-1993, segundo o vínculo institucional e a posição ocupada na autoria.

\begin{tabular}{|c|c|c|c|c|c|c|c|c|}
\hline \multirow{3}{*}{ VÍNCULO } & \multicolumn{6}{|c|}{ AUTOR } & & \\
\hline & \multicolumn{2}{|c|}{ Primeiro } & \multicolumn{2}{|c|}{ Segundo } & \multicolumn{2}{|c|}{ Terceiro } & \multicolumn{2}{|c|}{ TOTAL } \\
\hline & $N$ & $\%$ & $\mathrm{~N}$ & $\%$ & $\mathrm{~N}$ & $\%$ & $\mathrm{~N}$ & $\%$ \\
\hline Universidade Pública & 294 & 76,2 & 226 & 76,3 & 138 & 75,0 & 658 & 76,0 \\
\hline Universidade Privada & 26 & 6,7 & 18 & 6,1 & 15 & 8,2 & 59 & 6,9 \\
\hline Serviço Público Saúde & 33 & 8,6 & 29 & 9,8 & 19 & 10,3 & 81 & 9,3 \\
\hline Serviço Privado Saúde & 7 & 1,8 & 5 & 1,7 & 2 & 1,1 & 14 & 1,6 \\
\hline Outra Origem & 7 & 1,8 & 3 & 1,0 & 3 & 1,6 & 13 & 1,5 \\
\hline Ignorado & 19 & 4,9 & 15 & 5,1 & 7 & 3,8 & 41 & 4,7 \\
\hline TOTAL & 386 & 100,0 & 296 & 100,0 & 184 & 100,0 & 866 & 100,0 \\
\hline
\end{tabular}


$\mathrm{Na}$ categoria "Outra origem", correspondente a 13 autores $(1,5 \%)$ foram incluídos aqueles que referiram, entre outras, "EAP-APCD" [EAP = Escola de Aperfeiçoamento Profissional; APCD = Associação Paulista de Cirurgiões-Dentistas], "Sindicato dos Odontologistas", "Coletivo Odonto" e "Federação Interestadual dos Odontologistas".

Quanto à titulação dos autores, observa-se (Tabela 3) que há uma relativa homogeneidade na distribuição das diferentes titulações, oscilando em torno de 5 a $10 \%$ para cada categoria. Merecem destaque, entretanto, as categorias de titular e de mestre. Verifica-se que os titulares aparecem mais como segundo $(8,8 \%)$ e terceiro $(11,4 \%)$ autor, do que como primeiro autor $(5,7 \%)$. Os mestres, ao contrário, aparecem mais como primeiro autor $(9,3 \%)$ do que como segundo $(3,0 \%)$ ou terceiro autor $(1,6 \%)$. Essa característica da distribuição dos autores segundo sua titulação pode ser explicada pela tendência de titulares participarem como co-autores em trabalhos resultantes de pesquisas nas quais atuaram como orientadores e de mestres publicarem artigos resultantes de pesquisas relacionadas aos seus estudos de pós-graduação. Com efeito, observa-se que dos 22 artigos em que titulares aparecem como primeiro autor, em 14 $(63,6 \%)$ não há relação com dissertação/tese e em $7(31,8 \%)$ não havia suficiente informação no texto. Em apenas 1 artigo $(4,5 \%)$ havia relação com dissertação/tese. Por outro lado, nos 36 artigos em que o primeiro autor foi apresentado como "mestre", em apenas $6(16,7 \%)$ não havia relação com dissertação/tese.

É pertinente registrar que, tendo havido produção científica relacionada a algum domínio temático próprio da área de OPS, o(s) autor(es) foi considerado como "da área de OPS”, para a finalidade da presente investigação. Esta opção foi feita em virtude de 
os artigos não apresentarem, na ampla maioria das vezes, informações suficientes para que se pudesse fazer a distinção, individualizando-os, odontopediatras, periodontistas e ortodontistas, por exemplo. Dessa forma, há superestimação, em grau que não se pode conhecer, da produção específica de autores vinculados stricto sensu à área de OPS. Não se pretende, com essa consideração, considerar a área de OPS “território privado" de quem quer que seja, tampouco dos especialistas desta área. Aliás, cabe assinalar que não é exagero afirmar que o desenvolvimento da teoria-prática nesta área será tanto maior e melhor quanto mais os não-especialistas dessa área a ela se dedicarem. 
Tabela 3. Autores de artigos sobre Odontologia Preventiva e Social em periódicos brasileiros selecionados, no periodo 1986-1993, segundo a respectiva titulação e a posição ocupada na autoria.

\begin{tabular}{|c|c|c|c|c|c|c|c|c|}
\hline \multirow{3}{*}{ TITULAÇÃO } & \multicolumn{6}{|c|}{ AUTOR } & & \\
\hline & \multicolumn{2}{|c|}{ Primeiro } & \multicolumn{2}{|c|}{ Segundo } & \multicolumn{2}{|c|}{ Terceiro } & \multicolumn{2}{|c|}{ TOTAL } \\
\hline & $\mathrm{N}$ & $\%$ & $\mathrm{~N}$ & $\%$ & $\mathrm{~N}$ & $\%$ & $\mathrm{~N}$ & $\%$ \\
\hline Titular & 22 & 5,7 & 26 & 8,8 & 21 & 11,4 & 69 & 8,0 \\
\hline Adj./LD/As. ${ }^{*}$ & 40 & 10,4 & 33 & 11,1 & 16 & 8,7 & 89 & 10,3 \\
\hline Doutor & 25 & 6,5 & 20 & 6,8 & 8 & 4,4 & 53 & 6,1 \\
\hline Mestre & 36 & 9,3 & 9 & 3,0 & 3 & 1,6 & 48 & 5,5 \\
\hline Especialista & 21 & 5,4 & 12 & 4,1 & 11 & 6,0 & 44 & 5,1 \\
\hline Graduado & 32 & 8,3 & 23 & 7,8 & 12 & 6,5 & 67 & 7,8 \\
\hline Outra & 153 & 39,6 & 123 & 41,5 & 76 & 41,3 & 352 & 40,6 \\
\hline Não informa & 57 & 14,8 & 50 & 16,9 & 37 & 20,1 & 144 & 16,6 \\
\hline TOTAL & 386 & 100,0 & 296 & 100,0 & 184 & 100,0 & 866 & 100,0 \\
\hline
\end{tabular}

(*) Adj./LD/As. = Adjunto ou Livre Docente ou Associado.

A categoria "Outra" inclui uma série de denominações como, por exemplo, "docente", "docente voluntário", "professor", "professor assistente", "professor colaborador", "residente", "pós-graduando", "aluno", "aluno de pós-graduação" e até uma inusitada "professora auxiliar do gabinete dentário" ${ }^{157}$. Como tais denominações não informam sobre a titulação do autor tiveram de ser incluídas nesta categoria.

A distribuição segundo o sexo (Tabela 4) mostra que a maioria dos autores é do sexo masculino $(547=63,2 \%)$. Observa-se que há diferença, nesse aspecto, quanto a ser 
primeiro, segundo ou terceiro autor. Os homens registram maior porcentagem $(66,9 \%)$ na categoria "terceiro autor". Essa porcentagem diminui para a categoria "segundo autor" $(64,2 \%)$ e mais ainda para "primeiro autor" $(60,6 \%)$. As características dessa distribuição revelam que, embora os homens detenham, em todas as categorias, maiores porcentagens na autoria (em torno de $2 / 3$ ), as mulheres apresentam porcentagens crescentes de autoria nas categorias terceiro, segundo e primeiro autor, respectivamente.

Tabela 4. Autores de artigos sobre Odontologia Preventiva e Social em periódicos brasileiros selecionados, no período 1986-1993, segundo a participação na autoria e o sexo.

\begin{tabular}{lccccccc}
\hline & \multicolumn{9}{c}{ SEXO } & \multicolumn{2}{c}{ TOTAL } \\
\cline { 2 - 5 } AUTOR & \multicolumn{2}{c}{ Masculino } & \multicolumn{2}{c}{ Feminino } & \multicolumn{2}{c}{ TOTA } & $\%$ \\
\cline { 2 - 5 } & $\mathrm{N}$ & $\%$ & $\mathrm{~N}$ & $\%$ & $\mathrm{~N}$ & $383^{(a)}$ & 99,2 \\
\cline { 2 - 6 } Primeiro & 234 & 60,6 & 149 & 38,6 & & $294^{(b)}$ & 99,3 \\
Segundo & 190 & 64,2 & 104 & 35,1 & & \\
Terceiro & 123 & 66,9 & 58 & 31,5 & $181^{(c)}$ & 98,4 \\
\hline TOTAL & 547 & 63,2 & 311 & 35,9 & 858 & 99,1 \\
\hline
\end{tabular}

(a) Em 3 casos $(0,8 \%)$ não foi possivel identificar o sexo do autor.

(b) Em 2 casos $(0,7 \%)$ não foi possível identificar o sexo do autor.

(c) Em 3 casos (1,6\%) não foi possível identificar o sexo do autor.

O sexo dos autores foi deduzido a partir dos seus nomes. Houve casos em que isso não foi possível, uma vez que certos nomes não permitem deduções desse tipo. Nomes como, entre outros, "Darci", "Noriaki", "Guaracilei" não indicam o sexo dos seus titulares. 
A forma de identificação dos autores adotada por alguns periódicos também não ajudou nesse sentido: CARVALHO, L.E.P., por exemplo, não permite identificar-lhe o sexo.

Informações sobre a origem geográfica da instituição do primeiro autor estão na Tabela 5. Observa-se que dos 386 primeiros autores, $214(55,4 \%)$ desenvolvem atividades profissionais no estado de São Paulo. Os estados com menor participação (apenas 1 primeiro autor $=0,3 \%$ ) foram: Amazonas, Ceará, Goiás, Mato Grosso do Sul, Paraíba e Piauí. Em 9 casos (2,3\%) a origem geográfica do primeiro autor é ignorada pois as informaç̃es contidas na publicação não permitiram identificá-la.

Não foram registrados "Primeiros autores" com atuação profissional no Amapá, Mato Grosso, Rondonia, Roraima, Sergipe e Tocantins.

A expressiva participação $(55,4 \%)$ do estado de São Paulo na distribuição apresentada na Tabela 5 é desproporcional à participação dessa unidade federativa no conjunto das instituições universitárias do país, com atuação na área odontológica, a qual se situa em torno de 30\%. Logo, seria de se esperar uma participação menor, compatível com essa proporção. Cabe menção, entretanto, aos incentivos à produção acadêmica existentes no estado de São Paulo, consubstanciados no sistema estadual de universidades públicas e na agência de financiamento de pesquisas do Estado (FAPESP Fundação de Amparo à Pesquisa do Estado de São Paulo), os quais provavelmente se constituem em fatores relevantes associados à referida liderança paulista. 
Tabela 5. Primeiros autores de artigos sobre Odontologia Preventiva e Social em periódicos brasileiros selecionados, no período 1986-1993, segundo a localização geográfica da instituição na qual desenvolve suas atividades profissionais.

\begin{tabular}{|c|c|c|}
\hline ESTADO & $\mathrm{N}$ & $\%$ \\
\hline São Paulo & 214 & 55,4 \\
\hline Rio Grande do Sul & 38 & 9,8 \\
\hline Rio de Janeiro & 30 & 7,8 \\
\hline Distrito Federal & 17 & 4,4 \\
\hline Bahia & 14 & 3,6 \\
\hline Santa Catarina & 13 & 3,4 \\
\hline Minas Gerais & 12 & 3,1 \\
\hline Paraná & 11 & 2,8 \\
\hline Pernambuco & 7 & 1,8 \\
\hline Alagoas & 4 & 1,0 \\
\hline Rio Grande do Norte & 3 & 0,8 \\
\hline Acre & 2 & 0,5 \\
\hline Espírito Santo & 2 & 0,5 \\
\hline Maranhão & 2 & 0,5 \\
\hline Pará & 2 & 0,5 \\
\hline Amazonas & 1 & 0,3 \\
\hline Ceará & 1 & 0,3 \\
\hline Goiás & 1 & 0,3 \\
\hline Mato Grosso do Sul & 1 & 0,3 \\
\hline Paraíba & 1 & 0,3 \\
\hline Piauí & 1 & 0,3 \\
\hline Não informa & 9 & 2,3 \\
\hline TOTAI. & 386 & 100.0 \\
\hline
\end{tabular}


Com efeito, CARVALHO ${ }^{17}$ (1995) refere que "em avaliação nacional feita pela CAPES no periodo de 90 e 91, havia 81 cursos de pós-graduação (mestrado e doutorado) em odontologia. Destes, 46 tinham conceito A e 21 conceito B. As universidades estaduais de São Paulo respondem por expressiva participação em cursos bem conceituados, respectivamente, 40 e 16 do total."

A discreta participação do Rio Grande do Norte $(0,8 \%)$ e mesmo do Rio de Janeiro $(7,8 \%)$ despertam atenção, uma vez que nesses estados existem, em universidades federais, cursos de pós-graduação com área de concentração em Odontologia Preventiva e Social, sendo lícito, portanto, esperar um maior número de publicações com origem nesses estados.

Cabe registro, também, à participação do Distrito Federal com $4,4 \%$ dos primeiros autores. Levando-se em conta suas características peculiares, situa-se numa significativa quarta posição.

Os dados revelam em síntese que permanece atual e pertinente a diretriz contida no Relatório Final da I CNSB ${ }^{83}$ indicando a necessidade de "Descentralização na aplicação de recursos para a pesquisa." 


\section{3. Os artigos}

Apenas $8,8 \%$ dos 386 artigos analisados relacionaram-se, de alguma forma, com estudos de pós-graduação, originando-se de dissertações de mestrado ou teses de doutoramento, conforme se observa na Tabela 6 . Em $49 \%$ dos artigos não foi possível saber se tiveram alguma relação com estudos nesse nível pois os autores não fizeram qualquer referência às pesquisas que deram origem aos artigos. A omissão desse tipo de informação constitui obstáculo importante a qualquer tipo de avaliação semelhante à realizada nesta investigação. Por melhor que seja, não há como um instrumento de avaliação possa ser útil nesses casos. Assim, ainda que em muitos casos houvesse indícios positivos da relação do artigo com atividades de mestrado ou doutorado, não havia certeza. Por essa razão o critério adotado foi classificar tais artigos na categoria “ignorada".

Dessa forma, a categoria "ignorada" foi utilizada sempre que não havia nenhuma informação no texto que permitisse relacioná-lo com trabalhos acadêmicos dessa natureza; ou, então, quando a informação não esclarecia o leitor suficientemente, deixando dúvidas quanto a modalidade de pesquisa que originou o artigo. Isto significa, portanto, que pode ter havido relação com dissertação ou tese mas o artigo não trazia essa informação. Pode-se admitir, por essa razão (omissão da informação pelos autores), que a porcentagem de $8,8 \%$ está subestimada. Ainda que subestimada, tal porcentagem põe em evidência essa condição para o conjunto dos trabalhos analisados. Nesta medida, mesmo que marcada pelas restrições apontadas, essa porcentagem esclarece sobre a variável em análise. 
Nos casos de não vinculação evidente, considerou-se a categoria "não".

TABela 6. Artigos sobre Odontologia Preventiva e Social em periódicos brasileiros selecionados, no período 1986-1993, segundo o tipo de artigo e sua relação com dissertações ou teses.

\begin{tabular}{|c|c|c|c|c|c|c|c|c|}
\hline \multirow{3}{*}{$\begin{array}{l}\text { TIPO } \\
\text { DE } \\
\text { ARTIGO }\end{array}$} & \multicolumn{6}{|c|}{ RELAÇÃO COM DISSERTAÇÃO OU TESE } & & \\
\hline & \multicolumn{2}{|c|}{ SIM } & \multicolumn{2}{|c|}{ NÃO } & \multicolumn{2}{|c|}{ IGNORADA } & \multicolumn{2}{|c|}{ TOTAL } \\
\hline & $\mathbf{N}$ & $\%$ & $\mathbf{N}$ & $\%$ & $\mathrm{~N}$ & $\%$ & $\mathrm{~N}$ & $\%$ \\
\hline $\begin{array}{l}\text { Artigo } \\
\text { Original }\end{array}$ & 26 & $\begin{array}{c}76,5 \\
(11,9)\end{array}$ & 63 & $\begin{array}{c}38,7 \\
(28,8)\end{array}$ & 130 & $\begin{array}{c}68,8 \\
(59,3)\end{array}$ & 219 & $\begin{array}{c}56,7 \\
(100,0)\end{array}$ \\
\hline $\begin{array}{l}\text { Artigo de } \\
\text { Divulgação }\end{array}$ & 2 & $\begin{array}{c}5,9 \\
(16,7)\end{array}$ & 9 & $\begin{array}{c}5,5 \\
(75,0)\end{array}$ & 1 & $\begin{array}{c}0,5 \\
(8,3)\end{array}$ & 12 & $\begin{array}{c}3,1 \\
(100,0)\end{array}$ \\
\hline $\begin{array}{l}\text { Revisão de } \\
\text { Literatura }\end{array}$ & 2 & $\begin{array}{l}5,9 \\
(4,9)\end{array}$ & 9 & $\begin{array}{c}5,5 \\
(21,9)\end{array}$ & 30 & $\begin{array}{c}15,9 \\
(73,2)\end{array}$ & 41 & $\begin{array}{c}10,6 \\
(100,0)\end{array}$ \\
\hline $\begin{array}{l}\text { Relato de Caso } \\
\text { Clínico }\end{array}$ & - & - & 2 & $\begin{array}{c}1,2 \\
(33,3)\end{array}$ & 4 & $\begin{array}{c}2,1 \\
(66,7)\end{array}$ & 6 & $\begin{array}{c}1,6 \\
(100,0)\end{array}$ \\
\hline Ensaio & 2 & $\begin{array}{c}5,9 \\
(2,6)\end{array}$ & 54 & $\begin{array}{c}33,1 \\
(71,1)\end{array}$ & 20 & $\begin{array}{c}10,6 \\
(26,3)\end{array}$ & 76 & $\begin{array}{c}19,7 \\
(100,0)\end{array}$ \\
\hline $\begin{array}{l}\text { Relato de } \\
\text { Experiência }\end{array}$ & 1 & $\begin{array}{c}2,9 \\
(3,4)\end{array}$ & 25 & $\begin{array}{c}15,4 \\
(86,3)\end{array}$ & 3 & $\begin{array}{c}1,6 \\
(10,3)\end{array}$ & 29 & $\begin{array}{c}7,5 \\
(100,0)\end{array}$ \\
\hline $\begin{array}{l}\text { Estudo } \\
\text { de Caso }\end{array}$ & 1 & $\begin{array}{c}2,9 \\
(33,4)\end{array}$ & 1 & $\begin{array}{c}0,6 \\
(33,3)\end{array}$ & 1 & $\begin{array}{c}0,5 \\
(33,3)\end{array}$ & 3 & $\begin{array}{c}0,8 \\
(100,0)\end{array}$ \\
\hline TOTAL & 34 & $\begin{array}{r}100,0 \\
(8,8)\end{array}$ & 163 & $\begin{array}{l}100,0 \\
(42,2)\end{array}$ & 189 & $\begin{array}{l}100,0 \\
(49,0)\end{array}$ & 386 & $\begin{array}{c}100,0 \\
(100,0)\end{array}$ \\
\hline
\end{tabular}

Cabe reiterar todavia que, conforme mencionado anteriormente, a baixa porcentagem de artigos relacionados ao ensino de pós-graduação acompanha uma 
tendência observada no conjunto da produção científica no campo da odontologia não sendo, portanto, uma característica específica da área de OPS. VIANNA ${ }^{400}$ (1987) observou que, em 1985, o Brasil contava com 52 cursos de pós-graduação em odontologia (39 em nível de mestrado e 13 em nível de doutorado), os quais formavam, anualmente, em média 130 mestres e 20 doutores. Segundo o autor, menos da metade das publicações científicas (artigos, livros, cursos e outras formas de comunicação científica) tinham origem nesses 52 cursos de pós-graduação. VIANNA concluiu que a produtividade é baixa, tomando como referência a média geral de todas as áreas: $85 \%$ da produção científica têm origem em cursos de pós-graduação. Aquele autor informa também que a produção média dos cursos de pós-graduação é 0,45 trabalho publicado por docente por ano.

Ainda que as características da área de OPS a tornem distinta das demais quanto ao tipo de conhecimento científico-tecnológico a ser produzido (enfatizando menos os aspectos clínico-biológicos e mais os aspectos epidemiológico-sociais), e ainda que essas características encontrem nos serviços de saúde um locus privilegiado à produção de conhecimentos, apenas $10,9 \%$ dos autores de artigos se originaram nos serviços, conforme referido anteriormente. É oportuno assinalar, entretanto, que mesmo com essa pequena participação nas autorias, os artigos originados nos serviços superaram, em quantidade, os com origem na universidade privada (Tabelas 2 e 7).

Tendo em vista os dados apresentados na Tabela 6, pode-se admitir a pertinência da crítica de VIANNA também à área de OPS, uma vez que apenas $8,8 \%$ dos artigos tiveram origem em centros de pós-graduação, porcentagem muitíssimo aquém dos $85 \%$ apontados por aquele autor. 
Cabe registrar, ainda sobre os artigos, que um mesmo artigo ${ }^{281}$ foi publicado em dois periódicos: na Revista Paulista de Odontologia, em 1986, e na Enciclopédia Brasileira de Odontologia, em 1987. Até o título é o mesmo, apenas substituindo-se a palavra "dentadura" por "dentição".

Essa tática (publicar em dois periódicos) foi também utilizada por GARRAFA ${ }^{143,} 144$ (1986) e por BARBOSA; MARQUES, \& BARBOSA ${ }^{24}$ (1990). Destes, o artigo "A odontologia dentro do contexto 'Saúde no Brasil"” foi publicado tanto na $R G O$ quanto no Odontólogo Moderno. Na $R G O$ a ordem dos autores é BARBOSA, C.M.R.; MARQUES, A.L.; BARBOSA, J.R.A. Já no Odontólogo Moderno o primeiro autor é MARQUES, A.L.

A forma comumente empregada nos textos científicos segue um padrão que se apresenta irresistível aos autores. A estrutura com "introdução-material e métodoresultados e discussão-conclusões-referências" é uma fórmula que se impõe a tal ponto que, mesmo quando inadequada, é empregada. Em "Crimes contra a saúde pública (...)", por exemplo, BERNABA ${ }^{42}$ (1986) escreve um típico ensaio mas o apresenta, desnecessariamente nesse tipo de texto, na forma clássica da "introdução-material e método-resultados e discussão-conclusões-referências".

Certas palavras parecem exercer um irresistível fascínio sobre os autores. Mas, retiradas do contexto técnico-científico onde têm um significado preciso, são muitas vezes empregadas despropositadamente, fora de contexto, com intenções que não se consegue compreender a partir dos textos. Assim, foram encontradas nos artigos expressões bisonhas como, por exemplo, "demonstramos a significância dos dentes" ou a 
"significância dos custos" ${ }^{374}$, ou "aplicabilidade do SUDS aos problemas de odontologia" $^{173}$.

Erros gramaticais são comuns em textos científicos e as notórias dificuldades que caracterizam a língua portuguesa geram dificuldades adicionais para os autores. $\mathrm{O}$ emprego inadequado, por exemplo, de "simples" preposições às vezes ameaça colocar tudo a perder. Veja-se, para ilustrar, este caso: “(...) constatou em regiões nãofluoretadas um decréscimo similar (...) Esta observação vem de encontro com os relatórios (...) Estes estudos nos mostram que (...) podemos esperar, num futuro bem próximo, similar redução (...)" ${ }^{185}$ [grifos meus]. Ora, se afirma-se que "vem de encontro", há uma negativa, uma oposição. Logo, não podemos esperar "similar redução" mas o oposto. Pelo conjunto do texto é possível compreender o que os autores quiseram dizer. Mas o que está no texto diz o contrário. Uma "simples" preposição mudando todo o sentido do que se está pretendendo comunicar...

\section{3. 1. TIPO DE ARTIGo}

Dentre os artigos examinados, $41(10,6 \%)$ eram revisões da literatura. Admitindo-se que esse tipo de artigo é, geralmente, uma simples sistematização de algum tema de interesse, atualizando-o, pode-se considerar elevada essa porcentagem. Outra porcentagem alta se refere aos ensaios. Este tipo de texto ocorreu em 76 dos 386 artigos correspondendo a $19,7 \%$. Juntos, revisões de literatura e ensaios somaram $30,3 \%$ do total. Pouco mais da metade dos textos $(56,7 \%)$ corresponderam à categoria artigo original. 
A expressiva diferença observada entre as freqüências das categorias relato de experiências e estudo de caso traduz as dificuldades encontradas pelos autores para empreender análises aprofundadas. Os $7,5 \%$ observados para relato de experiências contra os $0,8 \%$ para estudo de caso é revelador da opção pelo "conforto" da simples descrição em detrimento da desejável postura crítica ou de um necessário rigor metodológico. Não se deve desconsiderar, para compreender os números apresentados na Tabela 7 , as conhecidas dificuldades que exigências metodológicas, mesmo elementares, representam para boa parte dos autores.

Quanto à origem institucional verifica-se que mais de três quartas partes da produção têm origem na universidade pública, que responde por $84 \%$ dos artigos originais os quais significam $62,6 \%$ do tipo de artigo nela produzido. Os ensaios, com $17,0 \%$, são o segundo tipo de artigo mais produzido na universidade pública.

Merece destaque a participação dos serviços públicos de saúde no conjunto da produção. Com 33 artigos ( $8,5 \%)$ essa participação é superior à da universidade privada $(26$ artigos $=6,7 \%)$.

O relato de experiência e o ensaio são os tipos de artigos proporcionalmente mais freqüentes com origem nos serviços públicos de saúde, com $30,3 \%$ e $27,3 \%$, respectivamente. 
BELA 7. Artigos sobre Odontologia Preventiva e Social em periódicos brasileiros selecionados, no período 1986-1993, segundo o tipo de go e a origem institucional do primeiro autor.

\section{ORIGEM INSTITUCIONAL DO PRIMEIRO AUTOR}

\begin{tabular}{|c|c|c|c|c|c|c|c|c|c|c|c|c|c|c|}
\hline \multirow[t]{2}{*}{ [IPO DE ARTIGO } & \multicolumn{2}{|c|}{$\begin{array}{c}\text { Universidade } \\
\text { Pública }\end{array}$} & \multicolumn{2}{|c|}{$\begin{array}{c}\text { Universidade } \\
\text { Privada }\end{array}$} & \multicolumn{2}{|c|}{$\begin{array}{c}\text { Serviço } \\
\text { Público de } \\
\text { Saúde }\end{array}$} & \multicolumn{2}{|c|}{$\begin{array}{c}\text { Serviço } \\
\text { Privado de } \\
\text { Saúde }\end{array}$} & \multicolumn{2}{|c|}{ Outra Origem } & \multicolumn{2}{|c|}{ Ignorada } & \multicolumn{2}{|c|}{ TOTAL } \\
\hline & $\mathrm{N}$ & $\%$ & $\mathrm{~N}$ & $\%$ & $\mathrm{~N}$ & $\%$ & $\mathrm{~N}$ & $\%$ & $\mathrm{~N}$ & $\%$ & $\mathrm{~N}$ & $\%$ & $\mathrm{~N}$ & $\%$ \\
\hline Irtigo Original & 184 & $\begin{array}{c}62,6 \\
(84,0)\end{array}$ & 11 & $\begin{array}{l}42,3 \\
(5,0)\end{array}$ & 12 & $\begin{array}{l}36,4 \\
(5,5)\end{array}$ & 4 & $\begin{array}{l}57,1 \\
(1,8)\end{array}$ & 1 & $\begin{array}{l}14,3 \\
(0,5)\end{array}$ & 7 & $\begin{array}{l}36,8 \\
(3,2)\end{array}$ & 219 & $\begin{array}{c}56,7 \\
(100,0)\end{array}$ \\
\hline Irtigo de Divulgação & 11 & $\begin{array}{c}3,7 \\
(91,7)\end{array}$ & 1 & $\begin{array}{c}3,9 \\
(8,3)\end{array}$ & - & - & - & - & - & - & - & - & 12 & $\begin{array}{c}3,1 \\
(100,0)\end{array}$ \\
\hline ¿evisão de Literatura & 32 & $\begin{array}{c}10,9 \\
(78,1)\end{array}$ & 6 & $\begin{array}{c}23,1 \\
(14,6)\end{array}$ & - & - & 2 & $\begin{array}{l}28,6 \\
(4,9)\end{array}$ & - & - & 1 & $\begin{array}{c}5,3 \\
(2,4)\end{array}$ & 41 & $\begin{array}{c}10,6 \\
(100,0)\end{array}$ \\
\hline ielato de Caso Clínico & 2 & $\begin{array}{c}0,7 \\
(33,3)\end{array}$ & 1 & $\begin{array}{c}3,8 \\
(16,7)\end{array}$ & 1 & $\begin{array}{c}3,0 \\
(16,7)\end{array}$ & - & - & 1 & $\begin{array}{c}14,3 \\
(16,7)\end{array}$ & 1 & $\begin{array}{c}5,3 \\
(16,7)\end{array}$ & 6 & $\begin{array}{c}1,6 \\
(100,0)\end{array}$ \\
\hline 'nsaio & 50 & $\begin{array}{c}17,0 \\
(65,8)\end{array}$ & 7 & $\begin{array}{l}26,9 \\
(9,2)\end{array}$ & 9 & $\begin{array}{c}27,3 \\
(11,8)\end{array}$ & - & - & 4 & $\begin{array}{l}57,1 \\
(5,3)\end{array}$ & 6 & $\begin{array}{l}31,6 \\
(7,9)\end{array}$ & 76 & $\begin{array}{c}19,7 \\
(100,0)\end{array}$ \\
\hline elato de Experiência & 13 & $\begin{array}{c}4,4 \\
(44,8)\end{array}$ & - & - & 10 & $\begin{array}{c}30,3 \\
(34,5)\end{array}$ & 1 & $\begin{array}{l}14,3 \\
(3,4)\end{array}$ & 1 & $\begin{array}{l}14,3 \\
(3,4)\end{array}$ & 4 & $\begin{array}{c}21,0 \\
(13,8)\end{array}$ & 29 & $\begin{array}{c}7,5 \\
(100,0)\end{array}$ \\
\hline studo de Caso & 2 & $\begin{array}{c}0,7 \\
(66,7)\end{array}$ & - & - & 1 & $\begin{array}{c}3,0 \\
(33,3)\end{array}$ & - & - & - & - & - & - & 3 & $\begin{array}{c}0,8 \\
(100,0)\end{array}$ \\
\hline OTAL & 294 & $\begin{array}{l}100,0 \\
(76,2)\end{array}$ & 26 & $\begin{array}{r}100,0 \\
(6,7)\end{array}$ & 33 & $\begin{array}{r}100,0 \\
(8,6)\end{array}$ & 7 & $\begin{array}{r}100,0 \\
(1,8)\end{array}$ & 7 & $\begin{array}{r}100,0 \\
(1,8)\end{array}$ & 19 & $\begin{array}{r}100,0 \\
(4,9)\end{array}$ & 386 & $\begin{array}{c}100,0 \\
(100,0)\end{array}$ \\
\hline
\end{tabular}




\section{3. 2. TIPO de PESQUiSA}

As pesquisas do tipo survey são as mais freqüentes na área de OPS, correspondendo a $31,1 \%$ do total, conforme se observa na Tabela 8 . O quasiexperimento é a categoria líder com $16,6 \%$, seguida pelo survey analítico com $16,3 \%$. Os experimentos somaram apenas $7,2 \%$, confirmando a pequena inclinação dessa área para a investigação em condições de laboratório.

A expressiva porcentagem $(38,9 \%)$ que recai sobre a categoria "outro" na Tabela 8 deve-se, conforme assinalado anteriormente, à elevada proporção de artigos do tipo ensaio, relato de experiência e revisão de literatura.

Tabela 8. Artigos sobre Odontologia Preventiva e Social publicados em periódicos brasileiros selecionados, no período 1986-1993, segundo o tipo de pesquisa que lhes deram origem.

\begin{tabular}{lcc}
\hline TIPO DE PESQUISA & $\mathrm{N}$ & $\%$ \\
\hline Exploratória & 24 & 6,2 \\
Experimento & 28 & 7,2 \\
Quasi-Experimento & 64 & 16,6 \\
Survey Descritivo & 57 & 14,8 \\
Survey Analítico & 63 & 16,3 \\
Outro & 150 & 38,9 \\
\hline TOTAL & 386 & 100,0 \\
\hline
\end{tabular}




\section{3. 3. TítuLo}

Observa-se na Tabela 9 que menos de um quarto $(23,1 \%)$ dos títulos puderam ser considerados adequados, evidenciando as dificuldades encontrados pelos autores.

Os títulos apresentaram, muitas vezes, palavras e expressões que merecem registro, seja pelo inusitado, ambigüidade ou pelas impropriedades; ou, simplesmente, por revelarem deficiências dos autores para sintetizar, numa frase curta, suas preocupações temáticas.

"O uso do fio dental junto ao público", por exemplo, sugere uma aplicação singular (no público...) desse recurso de higiene bucal ${ }^{408}$.

Tabela 9. Artigos sobre Odontologia Preventiva e Social em periódicos brasileiros selecionados, no periodo 1986-1993, segundo a adequação do título.

\begin{tabular}{lcc}
\hline TÍTULO & $\mathrm{N}$ & $\%$ \\
\hline Adequado & 89 & 23,1 \\
Inadequado & 297 & 76,9 \\
\hline TOTAL & 386 & 100,0 \\
\hline
\end{tabular}

Outro problema com aplicação. HARARI \& GROISMAN ${ }^{173}$ (1992) fizeram o seguinte título: "A aplicação do SUDS na odontologia". O SUDS, cuja sigla significa "Sistema Unificado e Descentralizado de Saúde", foi o precursor do Sistema Único de 
Saúde (SUS) criado pela Constituição da República de 1988. Há nesse caso uma evidente inversão: obviamente não se trata de aplicar “o SUDS na odontologia” mas o oposto. O leitor menos informado pode supor que "SUDS" seja alguma nova técnica ou material utilizado na clínica odontológica.

Outros autores tiveram problemas com a escala: houve referência à "situação bucal de escolares brasileiros" ${ }^{64}$ quando, efetivamente, apenas se identificou a quantidade de Streptococcus mutans na saliva de escolares de 1 (uma) única escola no município de São Paulo. Os escolares são, de fato, brasileiros. Mas o título induz o leitor a esperar uma pesquisa de outra magnitude: com abrangência nacional.

Também PINTO ${ }^{287}$ (1987) cometeu deslize semelhante. O título "Situação odontológica do idoso no Brasil" promete um artigo cujo texto não cumpre a promessa: sua leitura não possibilita uma aproximação sequer razoável à situação odontológica do idoso no Brasil.

SILVA ${ }^{352}$ (1993) faz referência ao "panorama da saúde bucal no Acre" mas estuda apenas a demanda de somente 1 (um) centro de saúde, excetuando emergências, e ainda assim, "no turno da manhã"...

Esse tipo de promessa foi feita também em inglês. Em "The prevalence of dental caries in brazilian children aged 0 to 36 months" ${ }^{246}$ os autores permitem que o leitor pense tratar-se de um estudo epidemiológico abrangendo a população brasileira de 0 a 36 meses de idade. Observa-se que, ao contrário, o âmbito da investigação é a demanda à clínica odontológica da Universidade Estadual de Londrina, no período 1985-1990. 
Essa preocupação com o título e com a exata localização do objeto do artigo no espaço e no tempo não é sem razão. Em "Risco de cárie em bebês", REIS \& MOREIRA ${ }^{300}$ (1995) citam MORITA: “Em seus trabalhos, MORITA informa que $90 \%$ das crianças brasileiras [grifo meu] aos 12 meses de idade estão livres de cárie dentária, enquanto que aos 36 meses de idade mais de 50\% delas já apresentam a doença com um alto índice de lesões." Essa mudança da abrangência, de Londrina para o Brasil, não é autorizada pelos estudos publicados, os quais, conforme assinalado, se referem apenas à cidade paranaense e à sua região de influência sanitária.

Em "Importância da utilização da sacarose na cárie dental" 108 o leitor é levado a acreditar no absurdo de que, na presença da cárie dentária, a sacarose deve ser utilizada.

Houve também títulos redundantes, que pouco ou nada agregam de conhecimento, como por exemplo: "Alívio da dor: um fator de procura do setor odontológico em centro comunitário" ${ }^{344}$.

A propósito, MATOS ${ }^{216}$ (1988) critica os elementos que considera "supérfluos" em muitos titulos, exemplificando: "Considerações sobre...; Estudo do/da...; Investigações sobre...; Subsídios para...; Tentativa de...". Para o referido autor "ser claro e conciso é necessário, mas insuficiente: é preciso ser concreto."

Os problemas com os títulos não devem, entretanto, ser atribuídos, somente às dificuldades dos autores mas, conforme mencionado no Capítulo 4, também aos conselhos de editores dos periódicos, cujas normas de publicação não vêm contribuindo para que os títulos sejam adequados à finalidade de informar sobre $o$ quê, como, onde e quando. 


\section{3. 4. Financiamento}

$\mathrm{Na}$ ampla maioria dos artigos $(94 \%)$ não se consegue obter qualquer informação sobre a origem dos recursos empregados nos estudos que levaram à sua elaboração e publicação (Tabela 10).

Essa característica do material estudado deve ser posta em relevo pela sua importância. O que significa? Os autores não consideram importante registrar no artigo a(s) fonte(s) dos recursos utilizados? Os estudos que dão origem aos artigos são custeados pelos próprios autores, portanto com dispêndios pessoais? Pesquisar e publicar não são atividades devidamente valorizados nas suas instituições e, por essa razão, não se deve mencioná-las? Seria a atividade de pesquisa secundária, paralela e até mesmo prejudicial ao desenvolvimento de outras atividades, essas sim "importantes"? Ou, simplesmente, essa informação é considerada sem importância, havendo registro apenas quando exigida pelas agências financiadoras?

Lamentavelmente, essas questões escapam aos propósitos desta pesquisa, restando como interrogantes a serem explorados em outras investigações.

Observa-se, dentre os poucos artigos com informações sobre financiamento, a significativa participação da FAPESP, proporcionalmente semelhante à da CAPES Coordenação de Aperfeiçoamento de Pessoal de Nível Superior, corroborando a análise sobre a origem geográfica do "primeiro autor”, referida anteriormente.

Deve-se considerar ainda que, segundo CARVALHO 77 (1995) “na área de saúde bucal a demanda por auxílios à pesquisa é relativamente pequena (...) na FAPESP, em 
1992, representou $0,88 \%$ e em 1993 eles corresponderam a $1,29 \%$ do total de auxílios concedidos."

Tabela 10. Artigos sobre Odontologia Preventiva e Social publicados em periódicos brasileiros selecionados, no período 1986-1993, segundo a participação de agências de financiamento nas pesquisas que os originaram.

\begin{tabular}{lcr}
\hline AGÊNCIA DE FINANCIAMENTO & N & $\%$ \\
\hline CNPq - Conselho Nacional de Desenvolvimento Científico e Tecnológico & 9 & 2,3 \\
CAPES - Coordenação de Aperfeiçoamento de Pessoal de Nível Superior & 3 & 0,8 \\
FAPESP - Fundação de Amparo à Pesquisa do Estado de São Paulo & 3 & 0,8 \\
Outra & 8 & 2,1 \\
Sem informação & 363 & 94,0 \\
\hline TOTAL & 386 & 100,0 \\
\hline
\end{tabular}

A categoria "Outra" foi utilizada para agrupar as fontes de financiamento com menor tradição (SUS-MG, Johnson \& Johnson, Bolsa-Pesquisa Graduação/Unicamp, Rede CEDROS, DNSB-MS e DABI-ATLANTE, por exemplo) no financiamento de pesquisas, em relação às agências tradicionais. 


\section{3. 5. METODOLOGIA}

A abordagem das questões metodológicas feita nesta pesquisa é, conforme referido anteriormente, limitada. Não se pretendeu tratar esmiuçadamente, nas dimensões da epistemologia, da lógica e da hermenêutica, os aspectos metodológicos de cada um dos artigos analisados. É a partir desse referencial, portanto, que devem ser considerados os resultados sobre metodologia, segundo a classificação que a identifica como ADEQUADA ou INADEQUADA.

Observa-se na Tabela 11 que 341 artigos $(88,3 \%)$ foram considerados de metodologia "adequada".

Em relação ao tipo de pesquisa que deu origem ao artigo, desconsiderando os 150 artigos incluídos na categoria "outro", constatou-se que $83,1 \%$ dos artigos (196, num total de 236) foram considerados com metodologia adequada.

Ao se proceder o cruzamento das categorias da variável metodologia com as da variável tipo de artigo, selecionando-se nestes as categorias onde aspectos metodológicos incidem com maior significado (artigos do tipo original e estudo de caso), verificou-se que a porcentagem de artigos com metodologia adequada caiu para $82,9 \%$ ( 184 artigos, num total de 222 ).

Dentre os primeiros autores (Tabela 11) com titulação informada e bem definida, os doutores foram os que apresentaram maior porcentagem de artigos incluídos na categoria "adequada" $(88,0 \%)$, superando os titulares $(86,4 \%)$. Os professores adjuntos ou livres-docentes ou associados lideraram na categoria "inadequada", com 20,0\%, superando os graduados $(18,8 \%)$. 
TABELA 11. Artigos sobre Odontologia Preventiva e Social publicados em periódicos brasileiros selecionados, no período 1986-1993, segundo a titulação do primeiro autor e o emprego de metodologia adequada.

\begin{tabular}{|c|c|c|c|c|c|c|}
\hline \multirow{3}{*}{$\begin{array}{l}\text { TÍTULO } \\
\text { DO PRIMEIRO } \\
\text { AUTOR }\end{array}$} & \multicolumn{4}{|c|}{ METODOLOGIA ADEQUADA } & & \\
\hline & \multicolumn{2}{|c|}{ Sim } & \multicolumn{2}{|c|}{ Não } & \multicolumn{2}{|c|}{ TOTAL } \\
\hline & $\mathrm{N}$ & $\%$ & $\mathrm{~N}$ & $\%$ & $\mathbf{N}$ & $\%$ \\
\hline Titular & 19 & $\begin{array}{c}5,6 \\
(86,4)\end{array}$ & 3 & $\begin{array}{c}6,7 \\
(13,6)\end{array}$ & 22 & $\begin{array}{c}5,7 \\
(100,0)\end{array}$ \\
\hline Adj./LD/As. ${ }^{*}$ & 32 & $\begin{array}{c}9,4 \\
(80,0)\end{array}$ & 8 & $\begin{array}{c}17,8 \\
(20,0)\end{array}$ & 40 & $\begin{array}{c}10,4 \\
(100,0)\end{array}$ \\
\hline Doutor & 22 & $\begin{array}{c}6,5 \\
(88,0)\end{array}$ & 3 & $\begin{array}{c}6,7 \\
(12,0)\end{array}$ & 25 & $\begin{array}{c}6,5 \\
(100,0)\end{array}$ \\
\hline Mestre & 31 & $\begin{array}{c}9,1 \\
(86,1)\end{array}$ & 5 & $\begin{array}{c}11,1 \\
(13,9)\end{array}$ & 36 & $\begin{array}{c}9,3 \\
(100,0)\end{array}$ \\
\hline Especialista & 18 & $\begin{array}{c}5,3 \\
(85,7)\end{array}$ & 3 & $\begin{array}{c}6,7 \\
(14,3)\end{array}$ & 21 & $\begin{array}{c}5,4 \\
(100,0)\end{array}$ \\
\hline Graduado & 26 & $\begin{array}{c}7,6 \\
(81,3)\end{array}$ & 6 & $\begin{array}{c}13,3 \\
(18,8)\end{array}$ & 32 & $\begin{array}{c}8,3 \\
(100,0)\end{array}$ \\
\hline Outra & 141 & $\begin{array}{c}41,3 \\
(92,2)\end{array}$ & 12 & $\begin{array}{l}26,7 \\
(7,8)\end{array}$ & 153 & $\begin{array}{c}39,6 \\
(100,0)\end{array}$ \\
\hline Não informa & 52 & $\begin{array}{c}15,2 \\
(91,2)\end{array}$ & 5 & $\begin{array}{l}11,1 \\
(8,8)\end{array}$ & 57 & $\begin{array}{c}14,8 \\
(100,0)\end{array}$ \\
\hline TOTAL & 341 & $\begin{array}{l}100,0 \\
(88,3)\end{array}$ & 45 & $\begin{array}{l}100,0 \\
(11,7)\end{array}$ & 386 & $\begin{array}{c}100,0 \\
(100,0)\end{array}$ \\
\hline
\end{tabular}

(*) Adj./LD/As.= Adjunto ou Livre Docente ou Associado. 
A destacada participação dos mestres $(86,1 \%$ dos artigos com metodologia adequada) pode estar expressando uma positiva influência dos cursos de pós-graduação, cuja preocupação com as questões metodológicas são bastante conhecidas.

Quanto à origem institucional do primeiro autor, observa-se (Tabela 12) que nos artigos com origem em serviços públicos de saúde é proporcionalmente maior aqueles com metodologia adequada $(93,9 \%)$, superando nesta categoria tanto a universidade privada $(88,5 \%)$ quanto a universidade pública $(88,1 \%)$.

Tabela 12. Artigos sobre Odontologia Preventiva e Social em periódicos brasileiros selecionados, no periodo 1986-1993, segundo o vínculo institucional do primeiro autor e a adequação da metodologia.

\begin{tabular}{|c|c|c|c|c|c|c|}
\hline \multirow{3}{*}{$\begin{array}{l}\text { VÍNCULO } \\
\text { DO PRIMEIRO } \\
\text { AUTOR }\end{array}$} & \multicolumn{4}{|c|}{ METODOLOGIA } & & \\
\hline & \multicolumn{2}{|c|}{ ADEQUADA } & \multicolumn{2}{|c|}{ INADEQUADA } & \multicolumn{2}{|c|}{ TOTAL } \\
\hline & $\mathbf{N}$ & $\%$ & $\mathbf{N}$ & $\%$ & $\mathrm{~N}$ & $\%$ \\
\hline Universidade Pública & 259 & $\begin{array}{c}75,9 \\
(88,1)\end{array}$ & 35 & $\begin{array}{c}77,8 \\
(11,9)\end{array}$ & 294 & $\begin{array}{c}76,2 \\
(100,0)\end{array}$ \\
\hline Universidade Privada & 23 & $\begin{array}{c}6,7 \\
(88,5)\end{array}$ & 3 & $\begin{array}{c}6,7 \\
(11,5)\end{array}$ & 26 & $\begin{array}{c}6,8 \\
(100,0)\end{array}$ \\
\hline Serviço Público de Saúde & 31 & $\begin{array}{c}9,1 \\
(93,9)\end{array}$ & 2 & $\begin{array}{c}4,4 \\
(6,1)\end{array}$ & 33 & $\begin{array}{c}8,5 \\
(100,0)\end{array}$ \\
\hline Serviço Privado de Saúde & 6 & $\begin{array}{c}1,8 \\
(85,7)\end{array}$ & 1 & $\begin{array}{c}2,2 \\
(14,3)\end{array}$ & 7 & $\begin{array}{c}1,8 \\
(100,0)\end{array}$ \\
\hline Outra Origem & 6 & $\begin{array}{c}1,8 \\
(85,7)\end{array}$ & 1 & $\begin{array}{c}2,2 \\
(14,3)\end{array}$ & 7 & $\begin{array}{c}1,8 \\
(100,0)\end{array}$ \\
\hline Ignorado & 16 & $\begin{array}{c}4,7 \\
(84,2)\end{array}$ & 3 & $\begin{array}{c}6,7 \\
(15,8)\end{array}$ & 19 & $\begin{array}{c}4,9 \\
(100,0)\end{array}$ \\
\hline TOTAL & 341 & $\begin{array}{l}100,0 \\
(88,3)\end{array}$ & 45 & $\begin{array}{l}100,0 \\
(11,7)\end{array}$ & 386 & $\begin{array}{c}100,0 \\
(100,0)\end{array}$ \\
\hline
\end{tabular}


Cabe assinalar ainda que a metodologia foi, em alguns casos, tratada como se fosse irrelevante; procedimento sugestivo de que, ao leitor, bastaria confiar nos autores e nos resultados apresentados

Os exemplos apresentados a seguir, à guisa de mera ilustração, se referem, como não poderia deixar de ser, ao tratamento dado à metodologia tal como esta foi relatada em cada artigo. Não há aqui, qualquer juízo de valor e, evidentemente, há o pressuposto da honestidade intelectual dos pesquisadores, admitindo-se também que qualquer artigo pode resultar tanto de adequada metodologia descrita de modo inadequado, quanto de metodologia praticada inadequadamente mas descrita de modo adequado.

TODESCAN \& SIMA ${ }^{376}$ (1991), por exemplo, relatam sumariamente sua metodologia: "Foi realizada uma pesquisa-de-campo em locais de agrupamentos humanos homogêneos, como fábricas, escolas e hospitais onde foi distribuído o questionário abaixo, para o devido preenchimento." Isto é tudo que os autores consideraram necessário comunicar aos leitores sobre material e método.

VANTINE \& NARESSI ${ }^{384}$ (1992) também economizaram palavras ao descrever seu método: " $\mathrm{O}$ material consta de: [lista]. $\mathrm{O}$ método consta de dados fornecidos pelo Departamento de Informática e Assessoria Odontológica, consistindo em: [lista]." Além da economia, um problema conceitual: dados são obtidos empregando-se um método. Não é possível compreender que o método conste "de dados".

É reconhecido, entre os que se ocupam com questões metodológicas, que os meios utilizados para obtenção de dados podem comprometer-lhes a validade. É provável que isso tenha ocorrido na pesquisa de SAQUY, PECORA \& SAVIOLI ${ }^{332}$ 
(1990). Os autores descrevem seu método: “O questionário foi preenchido sempre pelo mesmo entrevistador, através de um contato telefônico com a atendente do cirurgiãodentista. Ao telefone, informava o entrevistador ser de uma casa de artigos odontológicos, com promoção de luvas e máscaras. Durante a conversa, perguntava-se a respeito dos meios de proteção usados pelo profissional contra moléstias infectocontagiosas. Evidentemente, após a entrevista, o entrevistador explicava o motivo real do telefonema. Foram utilizados o sistema telefônico e a forma de se apresentar como revendedor odontológico para verificar o uso ou não dos mecanismos de proteção por parte do profissional, pois as pessoas de um modo geral têm necessidade premente de enganarem-se."

O cuidado ético de esclarecer o propósito da comunicação telefônica não resolve o problema da confiança nos dados assim obtidos. O bias é evidente: o desinteresse em comprar qualquer coisa no momento do contato, ou a ocupação com algo considerado mais importante, ou ainda vários outros fatores intervenientes relevantes podem ter alterado a informação obtida, comprometendo irremediavelmente os resultados.

No referido texto, a conclusão "as pessoas de um modo geral [sic] têm necessidade premente de enganarem-se", é impertinente.

No momento da discussão dos resultados obtidos em suas pesquisas, pelo menos em um artigo os autores (SUNDEFELD, SALIBA \& SALIBA) ${ }^{366}$ se renderam ao clássico e inadequado "os dados falam por si só." Desnecessário reiterar que nenhum dado "fala por si só". Mas houve autor que deu tratamento inusitado aos seus dados. SCARPA ${ }^{334}$ (1990) relata que a formação da placa bacteriana foi reduzida "significativamente ao nível de 10,96\%". Tal porcentagem é surpreendente uma vez que, 
de modo geral, os autores trabalham com o nível de $5 \%$, ou $1 \%$, ou mesmo $10 \%$. Mas deve-se reconhecer que o nível de $10,96 \%$, pela raridade, surpreende e deixa intrigado o leitor mais atento.

A introdução indevida, porque inadequada, de modificações em instrumentos metodológicos clássicos como, por exemplo, o índice CPO-D (KLEIN \& PALMER, 1937 apud PINTO, 1989) ${ }^{292}$ foi feita por SILVA ${ }^{353}$ (1993). Este autor abandonou, sem maiores explicações ou justificativas, o critério de apresentar valores do CPO-D segundo idade, adotando a inédita categorização por séries escolares. Em conseqüência, obteve valores ( $3^{\mathrm{a}}$ série $=5,04 ; 4^{\mathrm{a}}$ série 6,08 ) não equivalentes aos normalmente obtidos (por idade) quando se emprega o índice CPO-D.

\section{4. Os temas}

Os temas dos artigos foram categorizados de modo que fosse possível classificálos segundo grandes agrupamentos temáticos, denominados domínios, conforme se observa na Tabela 13. Esse tipo de abordagem permitiu que cada artigo fosse incluído no mínimo em um e no máximo em três domínios, de tal forma que seu conteúdo fosse apreendido o mais amplamente possivel através dessa estratégia quantitativa, permitindo, assim, a construção de um painel temático representativo dos trabalhos analisados. Além disso, cada artigo foi identificado segundo o tema predominante. Essa identificação permitiu a elaboração de uma lista temática detalhada, apresentada no Anexo 2. Com base no tema predominante foi possível, também, compor a Tabela 14, identificando com 
maior exatidão do que a possível através da abordagem do(s) domínio(s), o tema objeto de cada artigo.

Cabe referência, pela oportunidade, à impossibilidade de se lançar mão, como recurso metodológico, de unitermos ou palavras-chave para classificação dos artigos. A inexistência ou precariedade dos descritores simplesmente impediu tal procedimento. Aliás, mais precariedade do que inexistência. Tais achados coincidem com a observação de MADEIRA, TAKAHASHI e CARVALHO ${ }^{201}$ (1989). Pesquisando o emprego de unitermos pelos autores, em revistas nacionais de odontologia, encontraram "muitos deles impróprios, inexatos e até mesmo ingenuamente insólitos" exemplificando fartamente: "modo de ação; efeitos adversos; sexos; hígidos; recursos clínicos; efeitos biológicos; método indireto; (...) cuidados; endo-pério; intra-ósseo; baixo custo; raios de sol; ângulo; área lateral; impregnação; C. e O.; guiado não forçado; vínculo; racional; ecologia; acesso; aguda; freqüência; literatura; cobertura total; (...) Tuiuti, São Paulo, Brasil; Garça-SP; (...) de idade maior alegando idade menor; perícia em réu sob custódia; (...) subsídios democráticos para o atendimento odontológico pelo M.P.A.S., Instituições Estaduais, Municipais ou iniciativa privada; (...").

Verifica-se, na Tabela 13, a hegemonia do domínio "Prevenção de Doenças Bucais - Sistemas de Prevenção" no qual foram classificados 173 artigos. Isto significa que a temática da prevenção esteve presente, de modo relevante (domínios 1 ou 2 ou 3), em $44,8 \%$ dos 386 artigos examinados, predominando (domínio 1) em $112(29,0 \%)$. Vale destacar, também, o domínio temático "Epidemiologia - Processo Saúde/Doença", com 149 artigos (38,6\% dos 386 artigos) e predominância (domínio 1) em 80 (20,7\%). 
Ainda com base nos dados apresentados na Tabela 13 observa-se que, excetuando-se a modesta participação da "Ética em Saúde" (um único artigo = 0,2\%), os demais domínios aparecem com razoável presença. Mesmo em domínios temáticos onde, pelas características do trabalho odontológico, se poderia esperar uma produção mais escassa, como "Controle de Doenças - Vigilância Epidemiológica", constata-se a presença (domínios 1 ou 2 ou 3 ) de 14 artigos (3,6\% do total). Ainda que esse agrupamento tenha predominado (domínio 1) em apenas 2 artigos $(0,5 \%)$, os números são expressivos e merecem registro.

Levando-se em conta as 802 inserções em domínios distintos (no mínimo uma; no máximo três por artigo) observa-se que a produção científica abrangeu, de alguma forma, as diferentes dimensões da área de OPS. A ênfase aos domínios da prevenção e da epidemiologia são plenamente justificáveis, tendo em vista o papel nuclear que exercem na área.

O cruzamento das variáveis domínio e origem institucional do primeiro autor revela que $33,3 \%$ dos artigos com origem nos serviços públicos de saúde corresponderam ao domínio "Política de Saúde”. Esse domínio significou apenas 6,1\% dos artigos com origem na universidade pública. Tais porcentagens confirmam que as questões relacionadas às políticas de saúde têm maior acolhida nos serviços do que nas universidades. Em números absolutos a produção da universidade é maior (18 artigos) dos que a dos serviços públicos de saúde (11 artigos). 
BELA 13. Artigos sobre Odontologia Preventiva e Social em periódicos brasileiros selecionados, no periodo 1986-1993, segundo nínio temático.

\begin{tabular}{|c|c|c|c|c|c|c|c|c|}
\hline \multirow[t]{2}{*}{ วOMÍNIO TEMÁTICO } & \multicolumn{2}{|c|}{ DOMÍNIO 1} & \multicolumn{2}{|c|}{ DOMÍNIO 2} & \multicolumn{2}{|c|}{ DOMÍNIO 3} & \multicolumn{2}{|c|}{ TOTAL } \\
\hline & $\mathrm{N}$ & $\%$ & $\mathrm{~N}$ & $\%$ & $\mathrm{~N}$ & $\%$ & $\mathrm{~N}$ & $\%$ \\
\hline Ziência e Tecnologia - Produtos de Uso Odontológico & 7 & 1,8 & 6 & 2,3 & 5 & 3,2 & 18 & 2,2 \\
\hline Jontrole de Doenças - Vigilância Epidemiológica & 2 & 0,5 & 6 & 2,3 & 6 & 3,9 & 14 & 1,7 \\
\hline Joenças e Agravos à Saúde Relacionados ao Processo de Trabalho & 24 & 6,2 & 6 & 2,3 & 2 & 1,3 & 32 & 4,0 \\
\hline ducação em Saúde - Motivação - Relação Profissional/Paciente & 33 & 8,5 & 23 & 8,8 & 8 & 5,2 & 64 & 8,0 \\
\hline nsino Odontológico & 11 & 2,9 & 14 & 5,4 & 8 & 5,2 & 33 & 4,1 \\
\hline pidemiologia - Processo Saúde/Doença & 80 & 20,7 & 44 & 16,8 & 25 & 16,1 & 149 & 18,6 \\
\hline tica em Saúde & - & - & 1 & 0,4 & - & - & 1 & 0,2 \\
\hline egislação - Odontologia Legal & 10 & 2,6 & 2 & 0,8 & - & - & 12 & 1,5 \\
\hline rganização - Gerenciamento - Administração - Ergonomia & 25 & 6,5 & 29 & 11,1 & 21 & 13,5 & 75 & 9,3 \\
\hline slitica de Saúde & 35 & 9,1 & 10 & 3,8 & 12 & 7,7 & 57 & 7,1 \\
\hline evenção de Doenças Bucais - Sistemas de Prevenção & 112 & 29,0 & 48 & 18,4 & 13 & 8,4 & 173 & 21,7 \\
\hline ogramas/Financiamento - Sistemas de Saúde Coletiva - Acesso & 14 & 3,6 & 42 & 16,1 & 30 & 19,4 & 86 & 10,7 \\
\hline cursos Humanos & 18 & 4,7 & 13 & 5,0 & 20 & 12,9 & 51 & 6,3 \\
\hline gilância Sanitária & 15 & 3,9 & 17 & 6,5 & 5 & 3,2 & 37 & 4,6 \\
\hline ITAL & 386 & 100,0 & 261 & 100,0 & 155 & 100,0 & 802 & 100,0 \\
\hline
\end{tabular}


Alguns domínios, como "recursos humanos" ou "ética em saúde", por exemplo, abarcam temas cuja pertinência não requer maiores explicações. Outros agrupamentos, entretanto, precisam ser justificados:

CIÊNCIA E TECNOLOGIA - PRODUTOS DE Uso ODONTOLÓGICO: foram incluídos artigos cuja temática se referia, de alguma forma, às questões de ciência e tecnologia relacionadas à saúde bucal. Quanto aos produtos, procurou-se abranger equipamentos, instrumentos e materiais de uso na clínica odontológica e produtos de higiene bucal.

CONTROLE DE DOENÇAS - VIGLÂNCIA EPIDEMIOLÓGICA: O artigo abordava alguma série histórica ou de aspectos que evidenciavam a intenção de tratar o processo saúde-doença numa perspectiva de controle de doenças segundo bases populacionais.

\section{Doenças e agravos à Saúde Relacionados ao Processo de TRABalHo:}

neste caso "processo de trabalho" foi considerado em toda sua abrangência, significando não apenas processo de trabalho "odontológico" mas qualquer processo de trabalho.

EDUCAÇÃo EM SAÚdE - MOTIVAÇÃo - RELAÇÃo PROFISSIONAL/PACIENTE: nesse agrupamento foram incluídos os artigos que se ocuparam das questões relacionadas à educação em saúde e também de áreas de conhecimento com interface importante para a educação como o são as que se referem à motivação e à relação profissional-paciente.

ENSINO ODONTOLÓGICO: aqui se enquadraram os artigos cuja temática se referia às questões da formação (educação regular) e das diferentes modalidades de educação profissional, como educação continuada, educação permanente etc. Ações de educação "em saúde" ou "para saúde" não foram inseridas neste agrupamento. 
ORGANIZAÇÃO - GERENCIAMENTO - ADMINISTRAC̨ÃO - ERGONOMIA: foram aqui incluidos os artigos que tratavam de temas administrativos lato sensu, de sistemas (consultórios tradicionais e módulos clínicos fixos ou transportáveis) e técnicas de trabalho (quatro e seis mãos, por exemplo) e também os que abordavam questões relativas à postura física de profissionais e auxiliares, e outros aspectos relacionados ao binômio "tempo-movimento" na prática odontológica.

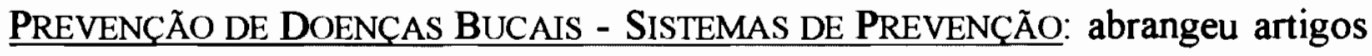
que se referiam a métodos, técnicas, medidas, ações e produtos (materiais ou instrumentos) empregados com finalidade preventiva.

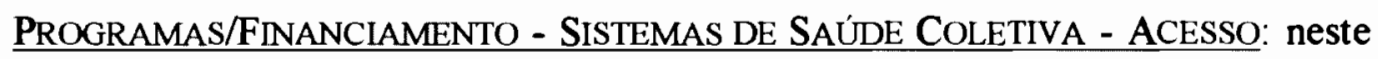
agrupamento foram classificados os artigos cujos temas tratavam de sistemas de atendimento, de características da demanda aos serviços odontológicos, da atenção à saúde bucal de grupos populacionais, considerados coletivamente, de ações programáticas e de aspectos do financiamento de serviços e ações de saúde, incluindo os referentes ao processo de implementação do SUS.

POLÍTICA DE SAÚDE: foram incluídos nesta categoria os artigos que abordavam aspectos das intervenções do poder público no campo da saúde, incluindo a "saúde bucal", ou outras manifestações coletivas relacionadas às iniciativas ou omissões do Estado neste campo.

VIGLÂACIA SANITÁRIA: este agrupamento compreendeu os artigos que, de alguma forma, se referiram ao papel do poder público no controle de bens e serviços de 
toda ordem que podem colocar em risco a saúde da população, relacionados com saúde bucal.

É pertinente registrar, a propósito, as conclusões da reunião promovida pelo CNPq em São Paulo (16/07/1982), sobre as diretrizes que deveriam ser seguidas na área odontológica ${ }^{195}$. Após afirmar que "é urgente promover a formulação de políticas de investigação odontológica", os participantes indicaram os seguintes "niveis de pesquisas":

“- INVESTIGAÇÃO SÓCIO-EPIDEMIOLÓGICA: compreende a caracterização qualitativa e quantitativa dos problemas de saúde bucal e sua correlação com os determinantes sócio-econômicos. Constitui o nível básico de pesquisa que irá determinar as prioridades e as formas de atuação; - INVESTIGAÇÃO CLINICO-PATOLÓGICA: compreende a investigação das distintas manifestaç̃es de doenças que afetam a cavidade bucal e as sistêmicas de interesse odontológico, o estudo experimental de seus mecanismos e dos modos de preveni-las, curá-las ou reabilitá-las. Uma maior ênfase deverá ser dada à pesquisa de métodos preventivos. $O$ planejamento desse tipo de pesquisa deve respeitar a ordem de prioridade que surja da investigação sócio-epidemiológica;

- INVESTIGAÇÃO DE MODELOS ALTERNATIVOS DE SERVIÇOS: medidas coletivas de prevenção e controle com prioridade para cárie, doença periodontal e câncer bucal; 
- ESTUDOS DE RACIONALIZAÇÃO DE RECURSOS humanos; estudos de racionalização de materiais de consumo, equipamentos, instrumental, sistemas de trabalho, espaço fisico e técnicas odontológicas; - PESQUISA TECNOLÓGICA, visando à substituição de importação de insumos odontológicos (...) segundo os seguintes critérios: prioridade para substituição de materiais e equipamentos de uso intensivo em atenção odontológica primária ou com maior peso na pauta de importações; existência de centros com competência para gerar tecnologia nacional; - PESQUTSA BÁSICA."

Como se observa, a abordagem por domínios empregada nesta investigação permitiu uma categorização dos temas, segundo a especificidade da área de OPS, cujo ponto de partida foi a classificação adotada pelo $\mathrm{CNPq}$. Embora não hierarquize os diferentes tipos de pesquisas e os temas, como o fez o $\mathrm{CNPq}$, a classificação por domínios apresenta maior diversidade de categorias. 
:LA 14. Artigos sobre Odontologia Preventiva e Social em periódicos brasileiros selecionados, no periodo 1986-1993, segundo o tema minante. (Parte I)

\begin{tabular}{|c|c|c|c|c|c|}
\hline :MA PREDOMINANTE & $\mathbf{N}$ & $\%$ & TEMA PREDOMINANTE & $\mathrm{N}$ & $\%$ \\
\hline DS & 1 & 0,3 & Epidemiologia da Cárie Dentária & 30 & 7,8 \\
\hline isistência Odontológica & 11 & 2,8 & Epidemiologia de Lesões da Cavidade Bucal & 1 & 0,3 \\
\hline estado Odontológico & 1 & 0,3 & Epidemiologia da Má Oclusão & 8 & 2,1 \\
\hline rão Sindical & 1 & 0,3 & Epidemiologia das Doenças Periodontais & 12 & 3,1 \\
\hline sbê & 4 & 1,0 & Ergonomia & 14 & 3,6 \\
\hline ossegurança & 2 & 0,5 & Escova de Dentes & 11 & 2,8 \\
\hline ìncer & 1 & 0,3 & Escovação Dentária & 5 & 1,3 \\
\hline árie Dentária & 9 & 2,3 & Estatura, estimativa & 1 & 0,3 \\
\hline ariogenicidade & 4 & 1,0 & Evidenciador de Placa & 1 & 0,3 \\
\hline idadania & 2 & 0,5 & Fio Dental & 3 & 0,8 \\
\hline entifrícios & 10 & 2,6 & Flúor & 23 & 5,9 \\
\hline 'ependência de Drogas & 1 & 0,3 & Fluoretação da Água & 13 & 3,4 \\
\hline conomia Profissional & 5 & 1,3 & Fluoretação do Açúcar & 1 & 0,3 \\
\hline ducação em Saúde & 8 & 2,1 & Fluoretação do Sal de Cozinha & 5 & 1,3 \\
\hline nsino Odontológico & 12 & 3,1 & Fluorose Dentária & 3 & 0,8 \\
\hline pidemiologia do Câncer Bucal & 7 & 1,8 & Goma de Mascar & 5 & 1,3 \\
\hline
\end{tabular}


BELA 14. Artigos sobre Odontologia Preventiva e Social em periódicos brasileiros selecionados, no período 1986-1993, segundo o tema dominante. (Parte II)

\begin{tabular}{|c|c|c|c|c|c|}
\hline IEMA PREDOMINANTE & $\mathrm{N}$ & $\%$ & TEMA PREDOMINANTE & $\mathrm{N}$ & $\%$ \\
\hline Higiene Bucal & 13 & 3,4 & Prescrição de Medicamentos & 1 & 0,3 \\
\hline Laser & 1 & 0,3 & Prevenção & 21 & 5,3 \\
\hline Má Oclusão & 1 & 0,3 & Processo Saúde-Doença & 2 & 0,5 \\
\hline Mercado de Trabalho & 6 & 1,5 & Promoção da Saúde & 1 & 0,3 \\
\hline Mercúrio & 6 & 1,5 & Recursos Humanos & 8 & 2,1 \\
\hline Motivação & 2 & 0,5 & Saliva & 5 & 1,3 \\
\hline Necessidades de Tratamento & 3 & 0,8 & Saúde Bucal & 14 & 3,6 \\
\hline Odontologia do Trabalho & 2 & 0,5 & Saúde Pública & 1 & 0,3 \\
\hline Periódicos Odontológicos & 1 & 0,3 & Selante & 15 & 3,8 \\
\hline Pessoal Auxiliar & 2 & 0,5 & Sistema de Saúde & 7 & 1,8 \\
\hline Placa Bacteriana Dental & 21 & 5,3 & Sistema Incremental & 2 & 0,5 \\
\hline Políticas de Saúde no Brasil & 3 & 0,8 & Tamanho de Dentes & 1 & 0,3 \\
\hline Prática Odontológica & 31 & 8,0 & Traumatismo Buco-Dentário & 1 & 0,3 \\
\hline TOTAL & & & & 386 & 100,0 \\
\hline
\end{tabular}


Como se pode observar na Tabela 14 , o conjunto relativo à "epidemiologia" das condições bucais predominou em $15 \%$ da produção científica na área de odontologia preventiva e social, com destaque para a epidemiologia da cárie dentária com metade $(7,8 \%)$ dessa produção. Outro conjunto a ser destacado refere-se, lato sensu, ao "flúor" com $10,9 \%$ dos artigos publicados. Mas deve-se assinalar que "flúor" foi também abordado em vários outros artigos, cujo tema predominante não era esse elemento como, por exemplo, nos textos sobre "dentifrícios" ou "prevenção". Houve casos entretanto em que, embora tratando de flúor, o artigo não foi considerado como "da área". Foram situações em que se abordava, por exemplo, "absorção e nefrotoxicidade após aplicação tópica". Mesmo relacionados aos interesses da área, estudos com tais características seriam melhor classificados em outras áreas de conhecimento e assim foram tratados.

Os dados da Tabela 14 mostram também a emergência de temas relacionados à ergonomia $(3,6 \%)$, selante $(3,8 \%)$ e placa bacteriana $(5,3 \%)$. A prevenção $(5,3 \%)$ e o conjunto "higiene bucal+motivação+educação+escovação" $(7,3 \%)$ expressam a crescente valorização dos temas relacionados à promoção da saúde bucal junto aos pesquisadores. Deve ser registrado também o interesse por novos produtos orientados à prevenção como, por exemplo, o selante uma vez que indica, claramente, uma preocupação com novas possibilidades tecnológicas capazes de imprimir novos rumos à prática odontológica. Em contrapartida, verifica-se que temas que despertavam grande interesse nos anos 50 e 60 como, por exemplo, os relacionados ao sistema incremental não ultrapassaram o percentual de $0,5 \%$ como tema predominante nos artigos examinados. Cabe destaque ainda à modestíssima participação de artigos onde temas 
relacionados às políticas de saúde bucal no Brasil tenham predominado. Tendo em vista as características do contexto do período de estudo (1986-1993), referidas anteriormente, essa "quase ausência" das políticas de saúde no conjunto da produção científica traduz o desinteresse e/ou as dificuldades dos autores em lidar com essa temática em bases científicas.

Tendo em vista o interesse especial dedicado nesta pesquisa à temática das políticas de saúde bucal, é pertinente a identificação dos artigos que delas se ocuparam especificamente. Foram os seguintes:

- Selantes e flúor em saúde pública: considerações sobre o "Programa Nacional de Controle da Cárie Dental com Uso de Selantes e Flúor" (BOTAZZO, MANFREDINI \& NARVAI, 1989) ${ }^{58}$;

- Emergência das políticas de saúde bucal no Brasil: uma análise do periodo 1923-1973 (VIANNA, 1989) ${ }^{396}$;

- Sobre a oportunidade de fluoretação do sal no Brasil: a modernidade do atraso. (NEDER \& MANFREDINI, 1991) ${ }^{252}$.

Além desses, em 32 outros artigos as temáticas relacionadas às políticas de saúde foram consideradas predominantes. Em vários casos 27, 40, 56, 90, 145, 173, 196, 209, 260, 290, 388, 397 havia referência, inclusive, à saúde bucal. Entretanto, apenas os três artigos anteriormente identificados trataram, especificamente, de iniciativas do poder público cujas ações, de intervenção no campo da saúde bucal, expressavam politicas de saúde.

Quanto à aparente pequena participação da AIDS $(0,3 \%)$, cabe esclarecer que o assunto esteve presente em vários trabalhos mas ao lado de outras doenças sexualmente transmissiveis e também relacionada à temática da biossegurança, da prática odontológica e da prevenção. 
Ainda que temas relacionados aos sistemas de saúde coletiva, ao acesso, e aos programas de saúde ou ao financiamento tenham predominado em 14 artigos, o sistema de saúde foi tema específico em 7. Dado o interesse especial que tais artigos têm nesta investigação, é pertinente identificá-los:

- Constituinte e a participação da odontologia (BARBOSA, 1986) ${ }^{27}$;

- Estrutura da prestação de serviços do setor público em odontologia no município de Salvador: um diagnóstico tendo em vista as ações integradas de saude (VIANNA \& SOUZA, 1986) ${ }^{397}$;

- Relacionamento entre padrões de doença e serviços de atenção odontológica (PINTO, 1989) ${ }^{290}$;

- A saúde bucal e a municipalização da saúde (CORDÓN, 1991) ${ }^{90}$;

- A aplicação do SUDS na odontologia (HARARI \& GROISMAN, 1992) ${ }^{173}$;

- Cidadania, saúde bucal e o SUS (BARBOSA, 1993) ${ }^{26,}$

- Saúde bucal e cidadania (GARRAFA, 1993) ${ }^{145}$.

Embora referenciados pela problemática do sistema de saúde pode-se observar, pelos títulos, que tais artigos remetem também ao domínio das politicas de saúde. Com efeito, todos estão classificados também neste domínio temático. Os artigos de CORDÓN (A saúde bucal e a municipalização da saúde) e de GARRAFA (Saúde bucal e cidadania), por exemplo, poderiam perfeitamente estar relacionados ao lado dos artigos cujo tema específico é a política de saúde, dada a pertinência de ambos à esse domínio. Foram considerados, todavia - apenas como recurso metodológico -, como sendo mais afetos à criação, implantação e desenvolvimento do SUS.

Foi também significativa a porcentagem de artigos relacionados aos produtos odontológicos de uso doméstico. O conjunto "escova + fio dental + dentifrício + 
evidenciador de placa" correspondeu a $6,5 \%$ do total dos artigos. Nesse conjunto, as escovas de dentes contribuíram com $2,8 \%$, revelando a crescente importância que os pesquisadores vêm atribuindo a esse tipo de produto.

Mas a ausência de perspectiva crítica de alguns pesquisadores não pode ficar sem menção. Essa ausência foi digna de nota, por exemplo, entre outros, nos trabalhos "O cloreto de cetilpiridínio e a placa bacteriana: uma revisão" (GRANJEIRO et al, 1993) ${ }^{162}$ e "Influência de bochechos com cepacol sobre a placa dentária. Parte I - Avaliação da quantidade de placa formada" (VONO et al, 1990) ${ }^{410}$. A própria opção temática (um agente terapêutico presente num dos produtos mais vendidos no mercado farmacêutico) implica abordar o problema do uso prolongado desse agente sobre a microbiota bucal. Não fazê-lo, tem um significado implícito: o leitor é levado a crer que se os pesquisadores não trataram desse aspecto é porque ele ou não é relevante ou encontra-se resolvido no plano científico. Mas, ao contrário, a análise da própria literatura consultada pelos referidos autores, mostra que não há qualquer evidência de que é seguro ou recomendável o uso continuado do produto ao longo dos anos. Este é um problema científico relevante. Ao leitor restam algumas questões: por que os autores não se colocam o problema do uso continuado? Tal problema não lhes teria ocorrido? Isso, sem entrar no mérito da eficácia preventiva do agente. Sobre esta suposta eficácia cabe referência ao artigo de GIORGI \& MICHELI ${ }^{154}$ (1992) no qual afirmam que produtos à base de cloreto de cetilpiridínio "não são aceitos pela ADA [American Dental Association] como redutores da placa e da gengivite."

Pelo significado da importante conclusão, aqui reproduzida, para o ensino odontológico e a prática profissional, cabe registro especial ao artigo de CAMPOS et al 
${ }^{69}$ (1988-89): “( $\left.\ldots\right)$ observa-se que $5,17 \%$ dos entrevistados neste estudo [realizado em Belo Horizonte] apenas lavam o instrumental clínico (...)" [grifos meus].

O sentimento de inferioridade nacional e a atribuição acrítica de valor ao que se faz no exterior, principalmente no denominado Primeiro Mundo, dá o tom geral à produção na área de OPS.

Segundo $\operatorname{COSTA}^{95}$ (1987) "não é novidade que a população brasileira é afetada em tomo de 100\% [sic] pela doença bucal mais conhecida, a cárie dentária. Como, infelizmente, somos recordistas em tudo, também o somos em índice de cárie na população."

Outro artigo, emblemático nesse sentido, é “A necessidade de prevenção da cárie nas crianças: programa japonês de prevenção da cárie dentária e como aplicá-lo ao nosso meio" de KOMORI et al ${ }^{176}$ (1991). Em primeiro lugar, deve-se registrar que a situação epidemiológica da cárie dentária é, de modo geral, melhor no Brasil do que no Japão. A evolução dos valores do índice CPO-D na idade-índice de 12 anos, nos últimos 50 anos revela, ao contrário do que está dito no referido artigo, que essa patologia tem registrado expressivo declínio no Brasil e discreto aumento no Japão. Assim, admitindo-se para efeito de raciocínio que programas de saúde alteram padrões epidemiológicos, aplicar o "programa japonês" em nosso meio seria inadequado pois, pode-se deduzir, pioraria nossa situação, em termos epidemiológicos. Em segundo lugar, conforme NARVAI ${ }^{251}$ (1994) programas de saúde não são replicáveis mas construções históricas singulares, únicas. Aliás, o referido artigo aborda, efetivamente, uma estratégia de intervenção no âmbito odontopediátrico (com bebês), já empregada com êxito no Brasil desde os anos 70, inicialmente na Universidade Estadual de Londrina, no Paraná, de onde se estendeu 
para várias regiões do país. Os autores estão, lamentavelmente, equivocados: parecem seduzidos pelo encantamento com o Primeiro Mundo e pressionados pela ideologia da suposta intrínseca incapacidade de os brasileiros criarem e realizarem algo de modo original e de acordo com a realidade do país e as necessidades da maioria da população.

Algumas assertivas, categóricas, não resistem às evidências. SPYRIDES et al ${ }^{365}$ (1993), discorrendo sobre o processo saúde-doença e defendendo uma abordagem holística, sustentam: “Assim, toda doença tem origem na mente." Tal afirmação, como se sabe, pode não resistir a um gole d'água ou a uma picada de mosquito - dependendo da qualidade da água e da espécie e condições do mosquito. 


\section{CONCLUSÕES}

Considerando os marcos dos procedimentos metodológicos adotados na presente investigação, a análise empreendida permite admitir, entre outras, as seguintes conclusões sobre a produção científica na área de odontologia preventiva e social no Brasil, no período de 1986 a 1993:

i) $R G O$ foi o periódico que mais freqüentemente publicou artigos na área de OPS, sendo seguido pela Revista da APCD. Pouco mais da metade dos textos $(56,7 \%)$ corresponderam à categoria artigo original. Revisões de literatura e ensaios somaram $30,3 \%$ do total. Há deficiência quantitativa na produção, a qual se situa em torno de no máximo $50 \%$ do potencial, mesmo computando-se a participação nessa produção "da área”, de autores vinculados às "áreas próximas" de periodontia e odontopediatria;

ii) a ampla maioria dos autores estavam vinculados profissionalmente a instituições universitárias públicas. Apenas 10,9\% deles registraram vínculo institucional com serviços de saúde. A maior parte é do sexo masculino. Mais da metade dos autores desenvolviam suas atividades no estado de São Paulo evidenciando a persistência da concentração de recursos para pesquisa neste Estado;

iii) é muito baixa a participação dos centros de pós-graduação no conjunto da produção. Mesmo assim, é significativo que mais de três quartas partes dessa produção tenha origem na universidade pública. Expressiva também é a participação dos serviços públicos de saúde, superior à da universidade privada;

iv) apenas $8,0 \%$ dos autores se apresentaram nas publicações como "professor titular". Os "Adjuntos", "livres-docentes" ou "associados" corresponderam a 10,3\%. 
Essa modesta participação de pesquisadores com maior titulação é coerente com a baixa produção constatada para centros de pós-graduação;

v) as pesquisas do tipo survey predominaram. Os experimentos corresponderam a apenas $7,2 \%$, confirmando a pequena inclinação da área para a investigação em condições de laboratório;

vi) a metodologia empregada pelos pesquisadores foi considerada "inadequada" em porcentagens que, dependendo da titulação dos autores, situaram-se entre 12 e 20 por cento;

vii) na ampla maioria dos artigos (94\%) não houve registro de informações sobre a origem dos recursos utilizados. Essa característica expressa tanto a pouco desenvolvida prática dos pesquisadores em buscar financiamento para esse tipo de produção científica quanto a ausência ou desconsideração, nas agências de fomento à pesquisa, de diretrizes políticas de investimento em investigações científicas na área odontológica voltadas à odontologia preventiva e social. Nos poucos documentos em que esse tipo de informação apareceu, observou-se que a FAPESP teve participação semelhante à da CAPES e ambas foram superadas pelo $\mathrm{CNPq}$;

viii) o domínio temático relacionado à prevenção de doenças bucais esteve presente, de modo relevante, em $44,8 \%$ dos artigos examinados, sendo seguido pela epidemiologia (38,6\%). Tal ênfase é plenamente justificável, uma vez que esses domínios exercem papel nuclear na área;

ix) fluor foi tema predominante em $10,9 \%$ dos artigos, tendo-se constatado a emergência de temas relacionados à ergonomia, aos selantes, à placa bacteriana e à promoção da saúde bucal. Verificou-se, por outro lado, que temas que despertavam 
grande interesse nos anos 50 e 60 como, por exemplo, os relacionados ao sistema incremental não ultrapassaram o percentual de $0,5 \%$ como tema predominante nos artigos examinados;

x) embora politica de saúde tenha sido domínio temático predominante em 7,1\% do total de registros (802), indicando que o tema se relacionava preponderantemente com essa questão, a politica de saúde foi tema específico em apenas 3 artigos $(0,8 \%)$. Considerando as características do período de estudo (1986-93), essa modestíssima participação indica desinteresse e/ou dificuldades dos autores em abordar essa temática. Merece destaque o interesse dos autores vinculados aos serviços públicos: seus 11 artigos incluídos no domínio temático politica de saúde corresponderam a $33,3 \%$ da sua produção. Sua participação no conjunto da produção sobre o tema correspondeu a $31,4 \%$, superando a universidade privada a qual, com apenas 1 artigo ficou em $2,9 \%$; xi) o sistema de sauide foi tema específico em 7 artigos (1,8\%). Essa produção, inferior a um artigo por ano, pode ser considerada quantitativamente pouco significativa, dada a relevância desse domínio temático.

As conclusões apresentadas indicam que, do ponto de vista quantitativo, a produção científica sobre política de saúde e sistema de saúde ficou aquém das potencialidades da área de odontologia preventiva e social. As características dessa produção no período estudado, considerada nessa dimensão quantitativa, não permite aceitar a hipótese que deu origem à presente investigação. Em conseqüência, ressalvada a possibilidade de alguma contribuição de alta relevância no interior da referida pequena produção e admitida a relação dialética entre quantidade e qualidade, os resultados obtidos indicam a necessidade de incremento na produção científica na área odontológica 
voltada, entre outras, às temáticas da política de saúde e do sistema de saúde, com vistas à produção dos conhecimentos necessários à superação do quadro atual de saúde bucal no Brasil. 


\section{REFERÊNCIAS BIBLIOGRÁFICAS}

1. ABDO, R.C.C.; MACHADO, M.A.A.M.; PAVARINI, A. Profilaxia prévia à aplicação tópica de flúor, sim ou não? Uma revisão. Revista de Odontologia da USP, 2 (3): 172-4, 1988.

2. ADDE, C.A. et al. Riscos de intoxicação aguda por compostos fluorados de uso odontológico. Revista da Associação Paulista de Cirurgiões-Dentistas, 47 (6): 1193-1202, 1993

3. AGUIAR, S.A.; PINTO, R.S. Assistência odontológica a autistas. $R G O, 40$ (5): 345 9, 1992.

4. ALI, M.D. et al. Avaliação dos primeiros molares: suas condições clínicas em estudantes com assistência odontológica. $R G O, 41$ (2): 115-8, 1993.

5. ALMEIDA, D. et al. Prevenção da cárie de radiação. $R G O, 41$ (3): 145-8, 1993.

6. ALMEIDA, I.C.S.; CARDOSO, A.C.; SILVA, R.H.H. Maloclusão em crianças: prevalência de contato prematuro em relação cêntrica. Estudo em escolares de Florianópolis. $R G O, \mathbf{4 0}(1): 11-4,1992$.

7. ALMEIDA, O.P.; SILVA, C.R.V.; SAIKI, P. Levantamento de lesões bucais. RGO, 35 (6): 471-3, 1987.

8. ALMEIDA, R.T.L.S. et al. Determinação do índice de placa dental em escolares da rede municipal de ensino de Ribeirão Preto-São Paulo. Revista Paulista de Odontologia, 13 (6): 11-4, 1991.

9. ALMEIDA, R.T.L.S. et al. Projeto aplicado na Secretaria Municipal de Saúde de Ribeirão Preto - Departamento de Odontologia Preventiva - Sugestões para um módulo de saúde oral. Revista Paulista de Odontologia, 13 (3): 21-4, 1991.

10. ALVES, A.R.B. et al. Clinical and laboratory evaluation of the ability of fluoride gels to reach approximal dental regions. Brazilian Dental Journal, 4 (2): 119-26, 1993. 
11. ALVES, D.F.; BURGOS, M.E.A. Avaliação clínica do Plax: sua eficiência na redução da placa supra-gengival. $R G O, 38$ (3): 163-5, 1990.

12. ALVES, M.C.R. A hipnose na área odontológica como auxiliar terapêutico. Revista da Associação Paulista de Cirurgiões-Dentistas, 40 (3): 226-31, 1986.

13. AMARANTE, L.A.; JTOMIRSKI, F.; AMARANTE, C.L.F. Flúor: beneficios e controvérsias dos programas de fluoretação. Revista Brasileira de Odontologia, 50 (4): 22-30, 1993.

14. AMATO NETO, V. Profilaxia da transmissão do HIV na atividade profissional de odontologistas. Revista Paulista de Odontologia, 11 (3): 16, 1989.

15. ANDRADE, M.T.D.; NORONHA, D.P. Técnica da pesquisa bibliográfica. 3a. ed. São Paulo, FSP-USP, 1972.

16. ANICET, J.C.; ANICET, B. Determinação do risco de cárie. $R G O, 36$ (2): 131-2, 1988.

17. ANTUNES, M.; ROSA, A.G.F. Vernizes com flúor. $R G O, 41$ (5): 279-80, 1993.

18. ARAÚJO, R.P.C.; ALMEIDA, J.C.S.; ARAÚJO, M.T.B. Determinação “in vitro" da capacidade de tamponamento da saliva humana frente à ação de diferentes dentifrícios. Revista da Faculdade de Odontologia da UFBA, 10/11: 12-5, $1990 / 1991$.

19. ARAÚJO, T.M; SILVA, C.H.T. Prevalência de maloclusões em escolares da Tlha do Governador, Rio de Janeiro. Parte II - Mordida aberta. Revista Brasileira de Odontologia, 43 (3): 8-16, 1986.

20. ARCIERI, R.M. et al. Estudo comparativo da prevalência da cárie dentária após 10 (dez) anos da adição de flúor nas águas de abastecimento público de UberlândiaMG. Revista Paulista de Odontologia, 8 (2): 46-55, 1986.

21. ARITA, E.S.; LASCALA, C.A.; VIANNA, R.B.C. Um novo conceito de ensino e trabalho em odontologia: desempenho lógico. Revista da Associação Paulista de Cirurgiões-Dentistas, 47 (4): 1105-10, 1993. 
22. AZEVEDO JR, P. et al. Descalcificação "in vitro". Ação da glicose e da frutose. Revista da Faculdade de Odontologia da UFBA, 10/11: 7-11, 1990/1991.

23. BARBERATO, M.A.C. et al. Cariogenicidade da merenda escolar. $R G O, 39$ (2): 127-33, 1991.

24. BARBOSA, C.M.R.; MARQUES, A.L.; BARBOSA, J.R.A. A odontologia dentro do contexto "Saúde no Brasil". RGO, 38 (2): 147-150, 1990.

25. BARBOSA, J.B.; MARCANTONIO JR, E.; BARBOSA, A.L.B. Avaliação das necessidades de tratamento periodontal em jovens alistados no serviço militar obrigatório. Revista de Odontologia da UNESP, 21: 171-80, 1992.

26. BARBOSA, S. Cidadania, saúde bucal e o SUS. Saúde em Debate, 39: 70-1, 1993.

27. BARBOSA, S.N. Constituinte e a participação da odontologia. Saúde em Debate, 18: $50-1,1986$.

28. BARDIN, L. L'analyse du contenu. Paris, PUF, 1977.

29. BARRETO, A.L. Um "ovo de Colombo" para tratar as crianças rebeldes. Odontólogo Moderno, 13 (5): 57-62, 1986.

30. BARROS, E.R.C. Antecedentes da fluoretação das águas de abastecimento público no município de Porto Alegre. Revista da Faculdade de Odontologia de Porto Alegre, 32 (2): 18-21, 1991.

31. BARROS, E.R.C. Metabolismo da placa cariogênica. Revista da Faculdade de Odontologia de Porto Alegre, 30/31: 16-22, 1990.

32. BARROS, E.R.C. O processo desmineralização-remineralização do esmalte dentário. $R G O, 37$ (3): 181-4, 1989.

33. BARROS, E.R.C.; SCAPINI, C.; TOVO, M.F. Resultados da fluoretação da água em localidade que sofreu descontinuidades de dosagens. $R G O, 41$ (5): 303-8, 1993.

34. BARROS, E.R.C.; TOVO, M.F.; SCAPINI, C. Análise crítica da fluoretação de águas no Município de Porto Alegre/RS. RGO, 38 (4): 247-54, 1990. 
35. BASTOS, J.R.M. et al. Redução na freqüência da ingestão de alimentos ricos em sacarose em escolares de 7-12 anos de idade, através da motivação. $R G O, 38$ (6): 470-7, 1990.

36. BASTOS, J.R.M.; LOPES, E.S. Efeito anticariogênico de bochechos semanais com soluções de fluoreto de sódio ou monofluorfosfato de sódio, após 32 meses em escolares de 9-12 anos de idade. Revista da Associação Paulista de CirurgiõesDentistas, 43 (1): 34-6, 1989.

37. BASTOS, J.R.M.; VIEGAS, A.R.; LOPES, E.S. Soluções de fluoreto de sódio a $0,2 \%$, monofluorfosfato de sódio a $0,7 \%$ e monofluorfosfato a $0,7 \%$ em álcool a $4 \%$, em bochechos semanais, na prevenção da cárie dentária. Resultados de 20 meses. (Comparação entre o uso). Revista da Associação Paulista de Cirurgiões-Dentistas, 40 (6): 443-5, 1986.

38. BELARDINELLI, V.H. Clínica particular: necessidade e possibilidade de fazê-la crescer. Odontólogo Moderno, 13 (10): 32-42, 1986.

39. BENITEZ, A.B.C.E.; DINELLI, W.; FULLER, J.B. Toxicidade do mercúrio: um perigo constante na odontologia. $R G O, \mathbf{4 1}$ (2): 119-22, 1993.

40. BERCHT, S.M.B. O preventivismo e o câncer de boca: o imobilismo que mata. Saúde em Debate, 37: 48-50, 1992.

41. BERNABA, J.M. Aspectos jurídicos na área trabalhista e cível de importância à classe odontológica. Revista da Associação Paulista de Cirurgiões-Dentistas, 40 (4): 298-9, 1986.

42. BERNABA, J.M. Crimes contra a saúde pública: aspectos criminológicos e jurídicopenais quanto à prescrição de medicamentos. (Infração legal e da ética profissional). Revista da Associação Paulista de Cirurgiões-Dentistas, 40 (6): 409-12, 1986.

43. BERNABA, J.M. Os direitos do cirurgião-dentista. Revista da Associação Paulista de Cirurgiões-Dentistas, 41 (3): 146-7, 1987. 
44. BERND, B. et al. Percepção popular sobre saúde bucal: o caso das gestantes do Valão. Saúde em Debate, 34: 33-9, 1992.

45. BERQUÓ, E.S.; SOUZA, J.M.P.; GOTLIEB, S.L.D. Bioestatística. São Paulo, EPU, 1980.

46. BERTON, F. Flúor em adultos. RGO, 34 (6): 524, 1986.

47. BIJELLA, M.F.T.B. et al. Avaliação clínica da aplicação de diamino-fluoreto de prata a $12 \%$ (bioride) na dentição decídua e seu efeito na incidência de cárie em primeiros molares permanentes. Revista Paulista de Odontologia, 13 (5): 28-35, 1991

48. BIJELLA, M.F.T.B.; BIJELLA, V.T. Educação e prevenção em saúde bucal do préescolar. $R G O, 38$ (6): 445-9, 1990.

49. BONA, A.D. A importância do flúor na odontopediatria de âmbito comunitário. Odontólogo Moderno, 17 (1/2): 17-22, 1990.

50. BORGES, S.R.; CAMPOS, S.M.; SAQUY, P.C. O sistema econômico e o exercício profissional odontológico. Parte VII - Concorrência em odontologia. Odontólogo Moderno, 14 (9): 17-9, 1987.

51. BORGES, S.R.; CAMPOS, S.M.; SAQUY, P.C. O sistema econômico e o exercício profissional odontológico. Parte VIII - Elasticidade - Preço da demanda. Odontólogo Moderno, 14 (10): 19-24, 1987.

52. BORGES, S.R.; CAMPOS, S.M.; SAQUY, P.C. O sistema econômico e o exercício profissional odontológico. Parte X. Odontólogo Moderno, 15 (4): 31-8, 1988.

53. BORGES, S.R.; CAMPOS, S.M.; SAQUY, P.C. O sistema econômico e o exercício profissional odontológico. Parte IX - O conceito de utilidade e o comportamento do consumidor individual. Odontólogo Moderno, 15 (3): 39-43, 1988.

54. BORGES, S.R.; CAMPOS, S.M.; SAQUY, P.C. Tempos no exercício profissional da odontologia (Um estudo com cirurgiões-dentistas de Ribeirão Preto). Parte VII. Odontólogo Moderno, 15 (9): 37-50, 1988. 
55. BORGES, S.R.; CAMPOS, S.M.; SAQUY, P.C. Utilização do computador para a elaboração de uma tabela de honorários profissionais odontológicos. Odontólogo Moderno, 16 (3): 32-42, 1989.

56. BOTAZZO, C. Democracia, participação popular e programas comunitários. Saúde em Debate, 18: 36-41, 1986

57. BOTAZZO, C.; MANFREDINI, M.A.; NARVAI, P.C. Força de trabalho em saúde bucal. Saúde em Debate, 24: 74-7, 1989.

58. BOTAZZO, C.; MANFREDINI, M.A.; NARVAI, P.C. Selantes e flúor em saúde pública: considerações sobre o "Programa Nacional de Controle da Cárie Dental com Uso de Selantes e Flúor”. RGO, 37 (2): 155-8, 1989.

59. BOTTI, M.R.V.; SANTOS, G.M.C. Perspectiva do exercício profissional na odontologia - Parte I: análise sobre as expectativas e dificuldades dos formandos. $R G O, 34$ (2): 155-9, 1986.

60. BRASIL, C.F.; OPPERMANN, R.V. Efeito comparativo da capacidade de limpeza interproximal do fio dental e palito com escova monotufo. Revista Brasileira de Odontologia, 44 (1): 2-7, 1987.

61. BRASIL. Ministério da Saúde. Coordenação Geral de Desenvolvimento de Recursos Humanos para o SUS. Formação superior em saúde: situação nacional por categoria profissional - 1985 a 1990. Brasília, CGDRH/SUS, 1992.

62. BREGAGNOLO, J.C. et al. Ocorrência da cárie dentária nas faces do primeiro molar permanente, em crianças. I - Dentes perdidos. Revista Paulista de Odontologia, 12 (5): 46-51, 1990.

63. BREGAGNOLO, J.C. et al. Ocorrência da cárie dentária nas faces do primeiro molar permanente, em crianças. II - Dentes cariados. Revista Paulista de Odontologia, 12 (6): 10-9, 1990.

64. BUISCHI, Y.P. et al. Situação bucal de escolares brasileiros: I - Prevalência de cárie dentária de s. mutans na saliva. Revista da Associação Paulista de Cirurgiões-Dentistas, 41 (6): 319-21, 1987. 
65. CALDAS, E.W.; BERVIQUE, J.A. Avaliação crítica do INTPC. RGO, 40 (3): 191 4, 1992.

66. CÂMARA FILHO, P. Odontoprevenção em consultório particular - $2^{\mathrm{a}}$ Parte. Odontólogo Moderno, 13 (1): 43-56, 1986.

67. CÂMARA FILHO, P. Odontoprevenção em consultório particular - $3^{\mathrm{a}}$ Parte. Odontólogo Moderno, 13 (2): 21-32, 1986.

68. CÂMARA, V.M. et al. Estudo comparativo dos efeitos da utilização de mercúrio por dentistas. Cadernos de Saúde Pública, 6 (2): 186-200, 1990.

69. CAMPOS, H. et al. Procedimentos utilizados no controle de infecção em consultórios odontológicos de Belo Horizonte. Arquivos do Centro de Estudos do Curso de Odontologia da UFMG, 25-26 (1/2): 46-52, 1988/1989.

70. CANDELÁRIA, L.F.A. et al. Estudo sobre motivação e reforço de motivação em escovação dentária, em escolares de 7 a 10 anos. Revista de Odontologia da UNESP, 18: 217-23, 1989.

71. CANO, A.M.G.; BOTAZZO, C. Aspectos psicológicos do tratamento odontológico. Saúde em Debate, 18: 42-9, 1986.

72. CAPELLA, L.F. et al. Ocorrência de fluorose dentária endêmica. $R G O, 37$ (5): 371 $5,1989$.

73. CAPELOZZA, A.L.A.; ALVARES, L.C. Avaliação das condições de radioproteção em consultórios odontológicos na cidade de Bauru-SP. Revista da Associação Paulista de Cirurgiões-Dentistas, 43 (4): 193-5, 1989.

74. CARCERERI, D.L. et al. Prevalência da cárie dentária em área de fluorose endêmica. $R G O, 37$ (6): 416-8, 1989.

75. CARDOZO, H.F.; CALVIELLI, I.T.P. Atestados odontológicos sob o ponto de vista legal. Odontólogo Moderno, 15 (6): 42-4, 1988.

76. CARVALHO, A.A. et al. O custo social da higiene oral na cidade de Salvador. Revista da Faculdade de Odontologia da UFBA, 7: 75-85, 1987. 
77. CARVALHO, A.C.P. Panorama sobre o ensino e a prática da odontologia no estado de São Paulo. In: "Estudo analisa o ensino e a prática da odontologia em São Paulo". APCD Jornal, fevereiro de 1995, p.18.

78. CARVALHO, E.M.C. O ensino odontológico - conscientização técnico-científica x aprendizagem artesanal. Revista da Faculdade de Odontologia da UFBA, 7: 4366, 1987.

79. CARVALHO, H.F.F. Experiência odontológica no bairro Maria Ortiz. Saúde em Debate, 18: 24-5, 1986.

80. CARVALHO, L.E.P. et al. Clorexidina em odontologia: uso do gluconato de clorexidina no controle da placa bacteriana. $R G O, 39$ (6): 423-7, 1991.

81. CAVALCANTI, A.J.; MIRANDA, V.C.; ROCCA, R.A. Ação antimicrobiana de pastas dentifrícias contendo ou não fluoreto. $R G O, 34$ (5): 366-70, 1986.

82. CIÊNCIA e Cultura. Novas normas para apresentação de originais. Ciência e Cultura, 38 (11): 1786-8, 1986.

83. CONFERÊNCIA NACIONAL DE SAÚDE BUCAL, 1a a Brasília, DF, 1986. Relatório Final. Brasília, Centro de Documentação do Ministério da Saúde, 1986.

84. CONFERÊNCIA NACIONAL DE SAÚDE BUCAL, 2a , Brasilia, DF, 1993.

Relatório Final. Brasilia, Conselho Federal de Educação, 1994.

85. CONFERÊNCIA NACIONAL DE SAÚDE, 7a , Brasilia, DF, 1980. Anais. Brasilia, Centro de Documentação do Ministério da Saúde, 1980. 280p.

86. CONRADO, C.A et al. The process of learning in undergraduate dental teaching: State University of Maringá Dental School. Brazilian Dental Journal, 4 (2): 1314, 1993.

87. CONRADO, C.A.; GOMES, G.S. Dental teaching in Brazil and the need for change. Brazilian Dental Journal, 2 (2): 145-6, 1991.

88. CONSELHO FEDERAL DE EDUCACAÇÃO. Resolução CFE 04/82, de 03/09/1982. 
89. CONSELHO FEDERAL DE ODONTOLOGIA. Resolução CF0-185/93, de 26/4/1993.

90. CORDÓN, J. A saúde bucal e a municipalização da saúde. Saúde em Debate, 32: $60-5,1991$.

91. CORDÓN, J. A saúde bucal e o mercado de trabalho odontológico. Saúde em Debate, 18: 52-64, 1986.

92. COSTA, B.; STEGUN, R.C.; TODESCAN, R. Do ensino à prática odontológica: um levantamento da realidade na Grande São Paulo. Revista da Associação Paulista de Cirurgiões-Dentistas, 46 (6): 909-13, 1992.

93. COSTA, B.; STEGUN, R.C.; TODESCAN, R. Realização profissional: uma avaliação entre os dentistas na Grande São Paulo. Revista da Associação Paulista de Cirurgiões-Dentistas, 46 (4): 821-4, 1992.

94. COSTA, J.E.; MARCOS, B. Determinação da necessidade de tratamento periodontal da população. Arquivos do Centro de Estudos do Curso de Odontologia da UFMG, 27 (1/2): 39-48, 1990.

95. COSTA, L.C.S. A odontologia em saúde pública. Odontólogo Moderno, 14 (7): 14$6,1987$.

96. COUTO, J.L.; COUTO, R.S.; DUARTE, C.A. Motivação do paciente: avaliação dos recursos didáticos de motivação utilizados para a prevenção da cárie e doença periodontal. $R G O, 40$ (2): 143-50, 1992.

97. CRUZ, R.A. A cárie vai diminuir. RGO, 41 (3): 190, 1993.

98. CRUZ, R.A. Avaliação clínica da efetividade dos dentifrícios fluoretados e o possível mecanismo de sua ação cariostática. Revista Brasileira de Odontologia, 50 (5): 3-8, 1993.

99. CURY, A.S.; MARCHETTI, R.M.; VERRI, R.A. Comentários sobre a legislação recente que regulamenta as drogas capazes de provocar dependência fisica e(ou) psíquica. Odontólogo Moderno, 13 (3): 55-63, 1986. 
100. CURY, J.A. Dentifrícios antiplaca no Brasil: avaliação do flúor. Revista da Associação Paulista de Cirurgiões-Dentistas, 42 (2): 168-70, 1988.

101. CURY, J.A. Dentifrícios fluoretados no Brasil. $R G O, 37$ (2): 139-42, 1989.

102. CURY, J.A. Estabilidade do flúor nos dentifrícios brasileiros. $R G O, 34$ (5): 430-2, 1986.

103. CURY, J.A. et al. Concentração de flúor no esmalte humano, após profilaxia com jato de bicarbonato ou taça de borracha, seguidos da aplicação tópica de flúor em gel. Revista Paulista de Odontologia, 9 (6): 54-9, 1987.

104. CURY, J.A. Flúor e câncer. Revista da Associação Paulista de CirurgiõesDentistas, 45 (5): 613, 1991.

105. CURY, J.A. Fluoretação da água: beneficios, riscos e sugestões. Revista Odontológica do Brasil Central, 2 (5): 32-3, 1992.

106. CURY, J.A. Saliva e saúde bucal. $R G O, 35$ (5): 418, 1987.

107. CURY, J.A.; GIL, P.S.S. Identificação dos pacientes com potencial cariogênico: avaliação preliminar do fluxo e da capacidade tampão salivar de brasileiros. $R G O, 36$ (2): 106-8, 1988.

108. DE LORENZO, J.L. Importância da utilização da sacarose na cárie dental - Parte I. Revista da Associação Paulista de Cirurgiões-Dentistas, 42 (6): 362-3, 1988.

109. DIACOV, N.; LIMA, J.R.S. Absenteísmo odontológico. Revista de Odontologia da UNESP, 17 (1/2): 183-9, 1988.

110. DINI, E.L. Retenção de selante oclusal. Revista Brasileira de Odontologia, 49 (5): 22-5, 1992.

111. DINI, E.L.; CASTELLANOS, R.A. Doenças periodontais em idosos: prevalência e prevenção para populações de terceira idade. Revista Brasileira de Odontologia, 50 (2): 3-9, 1993. 
112. DINI, E.L.; VERTUAN, V.; MENDES, A.J.D. Retenção de selante oclusal autopolimerizável: avaliação clínica após 6 e 12 meses. Revista de Odontologia da UNESP, 18: 233-9, 1989.

113. DINI, E.L.; VERTUAN, V.; PINCELLI, C.A.S. Condições bucais de escolares da área rural do Município de Araraquara-SP. Revista de Odontologia da UNESP, 22 (1): 125-33, 1993.

114. DINIZ, J. Evolução profissional da odontologia e alguns aspectos de sua prática atual: um depoimento. Revista da Faculdade de Odontologia da UFBA, 6: 10$32,1986$.

115. DOCKHORN, D.M.C.; HAHN, M.A.S. A formação de cirurgiões-dentistas para a odontologia do próximo século: o papel da disciplina de odontologia social. Odonto Ciência, 7 (14): 177-86, 1992.

116. DUARTE, R.C.; ISSAO, M. Efeito da combinação do método da aplicação do selante e do flúor tópico (aplicação clínica). Revista Paulista de Odontologia, 9 (3): 18-30, 1987.

117. ECO, U. Como se faz uma tese. 2a. ed. São Paulo, Perspectiva, 1985.

118. ENCONTRO NACIONAL DE ADMINISTRADORES E TÉCNICOS DO SERVIÇO PÚBLICO ODONTOLÓGICO (ENATESPO), 50, Recife, PE, 1988. Relatório Final. Recife, SES-SP/CADAIS, 1988.

119. FALCÃO, A.F.P. Avaliação do programa de aplicação tópica de flúor em dependentes de policiais militares de Salvador-Bahia. Revista da Faculdade de Odontologia da UFBA, 10/11: 42-53, 1990/1991.

120. FALCÃO, A.F.P.; MORAIS, A.A.S. Avaliação do estado de saúde bucal de policiais militares no $9^{\circ} \mathrm{BPM} / \mathrm{VC}$, Salvador-Bahia. Revista da Faculdade de Odontologia da UFBA, 12/13: 20-9, 1992/1993.

121. FANTINATO, V. et al. Exame bacteriológico da água em clínica odontológica. Revista da Associação Paulista de Cirurgiões-Dentistas, 46 (4): 829-31, 1992. 
122. FARACO, F.N.; MOURA, A.P.F. Controle do risco de transmissão de doenças infecto-contagiosas no consultório odontológico. Parte 1. Revista Paulista de Odontologia, 14 (6): 14-8, 1992.

123. FATINATO, V. et al. Esterilização e desinfecção em odontologia: AIDS e hepatite B. Revista Brasileira de Odontologia, 49 (5): 31-7, 1992.

124. FERLIN, L.H.M. et al. Prevalência da perda de primeiros molares permanentes, em escolares de 6 a 12 anos, de ambos os sexos, da cidade de Ribeirão Preto (SP). Revista de Odontologia da USP, 3 (1): 239-45, 1989.

125. FERRARI, A.P. et al. Sanguinarina como agente anti-placa. Revista da Associação Paulista de Cirurgiões-Dentistas, 47 (1): 977-9, 1993.

126. FERRAZ, T.A. Pesquisa bibliográfica nas ciências médicas. São Paulo, FOUSP, 1971.

127. FERREIRA, L.S.; FERRO, R.R. Técnicas de pesquisa bibliográfica e de elaboração de monografia. São Luis, APBEM, 1983.

128. FIGLIOLI, M.D. Postura de trabalho em odontologia. $R G O, 41$ (3): 155-60, 1993.

129. FIGLIOLI, M.D.; PORTO, F.A. Posições de trabalho para o cirurgião-dentista e auxiliar. Parte 1. Odontólogo Moderno, 19 (3): 14-20, 1992.

130. FIGLIOLI, M.D.; PORTO, F.A. Posições de trabalho para o cirurgião-dentista e auxiliar. Parte 2. Odontólogo Moderno, 19 (4): 24-31, 1992.

131. FIGLIOLI, M.D.; PORTO, F.A. Postura de trabalho em odontologia: avaliação das posições do cirurgião-dentista e da auxiliar odontológica. Odontólogo Moderno, 14 (5): 25-37, 1987

132. FIGUEIREDO, C.T.L.S.; TOLEDO, O.A.; BEZERRA, A.C.B. Freqüência de escovação dentária em escolares: em escola pública e escola particular em Brasília, DF. RGO, 40 (4): 261-4, 1992.

133. FONSECA, L. et al. Avaliação de dentifrício para limpeza de próteses totais. Odontólogo Moderno, 13 (6): 47-54, 1986. 
134. FONSECA, Y.P.; SANT'ANNA, G.R.; SUGA, S.S. Caso clínico: a primeira visita ao consultório dentário. Revista da Associação Paulista de CirurgiõesDentistas, 46 (4): 825-7, 1992.

135. FRANCO, E.M.; CURY, J.A. Bochecho com Plax e reatividade do flúor. $R G O, 41$ (5): 283-6, 1993.

136. FRANCO, K.D.; ISSAO, M. Manchas extrínsecas e sua relação com prevalência de cárie. Revista Paulista de Odontologia, 12 (3): 23-30, 1990.

137. FREITAS, S.F.T. Políticas de formação de recursos humanos em programas comunitários de saúde bucal. Saúde em Debate, 40: 43-7, 1993.

138. FREITAS, S.F.T.; PADILHA, W.W.N.; RIBEIRO, J.F. Educação e saúde: uma experiência em clínica integrada. Revista de Odontologia da USP, 6 (3/4): 147$50,1992$.

139. GARBELINI, M.L. et al. Avaliação do programa de odontologia para bebês no município de Cambé: controle e prevenção da cárie dentária - primeiros 30 meses. Saúde em Debate, 32: 75-7, 1991.

140. GARBELINI, W.T.; PAVARINI, A.; WALTER, L.R.F. Diamino fluoreto de prata - agente cariostático e anti-cariogênico. Enciclopedia Brasileira de Odontologia, 6: $185-8,1988$.

141. GARDUCCI, M.G.; LINO, A.P. Influência da fluoretação da água sobre os processos de rizólise e rizogênese. Revista da Associação Paulista de Cirurgiões-Dentistas, 46 (4): 835-9, 1992.

142. GARLIPP, O.F.; DIAS, N.M. Controle da placa com goma de mascar. $R G O, 34$ (2): 177-9, 1986.

143. GARRAFA, V. Odontologia do trabalho. $R G O, 34$ (6): 508-12, 1986.

144. GARRAFA, V. Odontologia do trabalho. Saúde em Debate, 18: 5-10, 1986.

145. GARRAFA, V. Saúde bucal e cidadania. Saúde em Debate, 41: 50-7, 1993. 
146 GARRAFA, V.; MOYSÉS, S.J. Odontologia brasileira: tecnicamente elogiável, cientificamente discutivel, socialmente caótica. Divulgação em Saúde, 13: 6-17, 1996.

147. GAVIÃO, M.B.D. et al. Primeiros molares permanentes: estudo da freqüência de irrompidos e cariados em escolares beneficiados pela fluoretação. Enciclopedia Brasileira de Odontologia, 6: 177-84, 1988.

148. GAVIÃO, M.B.D.; PETERS, C.F. Avaliação da retenção de selante e incidência de cárie em programa de prevenção. Estudo em molares decíduos. Revista da Associação Paulista de Cirurgiões-Dentistas, 46 (1): 701-4, 1992.

149. GEVAERD, S. et al. A capacitação de recursos humanos em odontologia e o Sistema Único de Saúde. Saúde em Debate, 29: 70-2, 1990.

150. GIL, A.C. Como elaborar projetos de pesquisa. 3a. ed. São Paulo, Atlas, 1994.

151. GIL, I.A.; MORAES, A.B.A. Treinamento de escovação dentária em crianças: uma análise de relatos de pesquisa. $R G O, 40$ (6): 401-4, 1992.

152. GIL, P.S.S. et al. Fluoretação do sal de cozinha: estudo metabólico. $R G O, 37$ (4): $271-3,1989$.

153. GIL, P.S.S.; CURY, J.A. Potencial cariogênico de gomas de mascar. $R G O, 34$ (2): $121-4,1986$.

154. GIORGI, S.M; MICHELI, G. Agentes químicos no controle da placa bacteriana. Resumo das conclusões do Congresso da American Academy of Periodontology - (AAP) - 1989. Revista da Associação Paulista de Cirurgiões-Dentistas, 46 (5): 857-60, 1992.

155. GIRON, M.C.C. et al. Estudo sobre a consulta preventiva em odontologia: realidade e sugestão. Odonto Ciência, 1 (1): 58-71, 1986.

156. GOIRIS, F.A.; BIJELLA, V.T.; GRIGOLLI, W.A. Modelos de coordenação cirurgião-dentista/auxiliar na técnica de trabalho a quatro mãos em periodontia, segundo a metodologia do sistema PERT. Parte 1. Odontólogo Moderno, 20 (3): 7-13, 1993. 
157. GOMES, R.L.F. et al. Condições clínicas dos dentes decíduos e permanentes de escolares da cidade de Lavras do Sul-RS-1985. Odontólogo Moderno, 15 (7): 31-8, 1988.

158. GONÇALVES, B.C.; UZEDA, M.; FEITOSA, A. Avaliação de dentifrícios com xilitol e/ou flúor. $R G O, 41$ (5): 267-70, 1993.

159. GONÇALVES, R.M.G.; SILVA, R.H.H. Escovação dentária com dispositivo de esponja plástica. $R G O, 34$ (6): 457-61, 1986.

160. GONÇALVES, R.M.G.; SILVA, R.H.H. Experiência de um programa educativopreventivo. $R G O, \mathbf{4 0}(2)$ : 97-100, 1992.

161. GONZÁLEZ, R.E.F. et al. Características epidemiológicas da prevalência da cárie dentária na dentição decídua, em pacientes de nível sócio-econômico médio-alto. Revista Paulista de Odontologia, 8 (1): 2-9, 1986.

162. GRANJEIRO, J.M. et al. O cloreto de cetilpiridínio e a placa bacteriana: uma revisão. Revista da Associação Paulista de Cirurgiões-Dentistas, 47 (2): 101921, 1993.

163. GREIN, N.J. et al. Doenças sexualmente transmissíveis (DST). Odontólogo Moderno, 13 (3): 30-2, 1986.

164. GROTH, E.B.; EDUARDO, C.P. Laser em prevenção. Revista da Associação Paulista de Cirurgiões-Dentistas, 47 (2): 1005-6, 1993.

165. GUEDES, M.L.S.; GUEDES, J.S. Bioestatística para profissionais de saúde. Rio de Janeiro-Brasília, Ao Livro Técnico-CNPq, 1988.

166. GUERRA, M.A.A. Treinamento de monitores indígenas em saúde bucal: uma experiência de trabalho com os ticunas. Saúde em Debate, ed.esp.: 42-4, janeiro 1988

167. GUERRINI, R.; ISSAO, M.; CURY, J.A. Influência da exposição prévia de ratas ao flúor antes da prenhez na sua incorporação nos dentes dos descendentes. Revista Paulista de Odontologia, 8 (3): 30-4, 1986. 
168. GUIMARÃES JR, J. Relação paciente/profissional: base para o sucesso clínico.

Parte I. Revista da Associação Paulista de Cirurgiões-Dentistas, 47 (2): 1013-8, 1993.

169. GUTMARÃES, A.C.A.C.; SILVA NETTO, C.R. Interação entre Secretaria Municipal de Saúde e Centro Comunitário. Revista Brasileira de Odontologia, 45 (6): 26-8, 1988.

170. GUIMARÃES, A.M.R.; SÁ, E.C.F. Cárie radicular em adultos: prevalência, aspectos clínicos, prevenção e tratamento. Revista da Associação Paulista de Cirurgiões-Dentistas, 45 (2): 85-8, 1990.

171. GUIMARÃES, L.O.C.; GUIMARÃES, A.M.R. Simplificação do índice CPO dos 18 aos 25 anos. Revista de Saúde Pública, 24 (5): 407-11, 1990.

172. HANAI, L.W. et al. Identificação cromatográfica de contaminação metálica em pastas dentifricias. Revista de Odontologia da UNESP, 22 (1): 65-72, 1993.

173. HARARI, S.G.; GROISMAN, M. A aplicação do SUDS na odontologia. $R G O, 40$ (1): 73-4, 1992 .

174. IMURA, N.; ZUOLO, M.L. Verificação da temperatura interna real de estufas em consultórios odontológicos. Revista da Associação Paulista de CirurgiõesDentistas, 44 (1): 49-51, 1990.

175. KALAMATIANOS, P.; NARESSI, W.G. Estudo comparativo do índice CPO antes e depois do advento da educação sanitária, nas escolas da rede municipal da cidade de São José dos Campos-SP. $R G O, 36$ (5): 327-30, 1988.

176. KOMORI, R.M.M. et al. A necessidade de prevenção da cárie nas crianças: programa japonês de prevenção da cárie dentária e como aplicá-lo ao nosso meio. Revista da Associação Paulista de Cirurgiões-Dentistas, 45 (4): 557-9, 1991

177. KOO, M.H.; CURY, J.A. Relação Ca:MFP na reatividade do flúor de dentifrícios. $R G O, 40$ (3): 232-4, 1992. 
178. KOWALSKI, L.P. et al. Modelo de programa de prevenção e detecção e detecção precoce do câncer bucal. Saúde em Debate, 32: 66-71, 1991.

179. KRAMER, P.F. et al. Os selantes oclusais, seus aspectos clínicos e a importância de um programa de prevenção. Revista da Associação Paulista de CirurgiõesDentistas, 45 (3): 473-7, 1991.

180. KUNERT, I.R. Estudo da ponta das cerdas das escovas em 40 diferentes marcas. $R G O, 40$ (4): 250-4, 1992.

181. KUNERT, I.R. et al. Motivação em saúde bucal: programa "Saúde pela boca". $R G O, 38$ (6): 450-6, 1990.

182. LACAZ NETO, R.; MACEDO, N.L.; ROSSETINI, S.M. Gomas de mascar e placa bacteriana. $R G O, \mathbf{3 4}$ (2): 107-10, 1986.

183. LACAZ NETTO, R. et al. Bochechos e formação de placa: efeito do sulfato de cobre, do Cepacol-flúor e do fluoreto estanhoso sobre a formação da placa bacteriana. $R G O, 39$ (6): 417-20, 1991.

184. LACAZ NETTO, R. et al. Controle da placa dentária: efeito da escovação orientada, do fluoreto estanhoso e da clorexidina sobre a formação da placa bacteriana. $R G O, 35$ (4): 259-63, 1987.

185. LACAZ NETTO, R. et al. Epidemiologia das doenças dentárias. Odontólogo Moderno, 16 (9): 7-15, 1989.

186. LACAZ NETTO, R et al. Estudo, pela microscopia eletrônica de varredura, de seis marcas de escovas dentárias, fabricadas no Brasil, novas ou após o uso em pacientes com e sem cálculo supragengival. Revista de Odontologia da UNESP, 18: 57-67, 1989.

187. LEE, E.N.C. et al. Efeito do mate e do chá, comparado ao do flúor, na prevenção da cárie em ratos. Estomatologia e Cultura, 16 (2): 17-22, 1986.

188. LIESENFELD, M.H. Pessoal auxiliar em odontologia. Revista da Faculdade de Odontologia da UFBA, 8-9: 50-62, 1988/1989. 
189. LOFFREDO, L.C.M. et al. Reprodutibilidade do indicador de saúde periodontal de Russel. Revista de Odontologia da UNESP, 17 (1/2): 139-43, 1988.

190. LOPES, T.S.P.; PARREIRA, M.L.J.; CARVALHO, P.V. Prevalência de lesão cariosa em primeiros molares permanentes de escolares residentes em regiões com flúor e sem flúor na água de abastecimento. (Estudo comparativo baseado em exames clínico e radiográfico). Arquivos do Centro de Estudos do Curso de Odontologia da UFMG, 25-26 (1/2): 12-21, 1988/1989.

191. LOPES, W.C.; NASCIMENTO, Z.C.P. Avaliação da preferência, uso e substituição de escovas dentais. Revista Odontológica do Brasil Central, 3 (9): 4-10, 1993

192. LORO, R.O.C. Ensino odontológico: câncer bucal. Odonto Ciência, 2 (3): 61-71, 1987.

193. LOTUFO, R.F.M; GIORGI, S.M. Infecção cruzada: existe no seu consultório? Revista da Associação Paulista de Cirurgiões-Dentistas, 45 (2): 105-7, 1990.

194. LOURES, L.B.H. et al. Conceitualização e formas de utilização do flúor. Saúde em Debate, 18: 26-8, 1986.

195. LOURO FILHO, P.P. Odontologia. In: SEPLAN. CNPq. Avaliação \& Perspectivas. Vol. VI, Ciências da Saúde, p. 437-93, 1982

196. LUVISON, I.R.; BALDISSEROTO, J. Trabalho comunitário em Vila Popular. Saide em Debate, 18: 21-4, 1986.

197. MACHADO, I.S. Programa especial de odontologia. Sanide em Debate, 30: 86-7, 1990.

198. MACIEL, R.A; HALLA, D. Controle da placa interproximal com fio dental. $R G O$, 35 (4): 274-6, 1987.

199. MACIEL, S.M.L. et al. Testes de atividade de cárie: sua aplicabilidade no consultório odontológico. $R G O, 41$ (6): 369-74, 1993.

200. MADEIRA, M.C.; CARVALHO, M.A. Tempo de vida das revistas nacionais de odontologia. $R G O, 36(4)$ : 301-6, 1988. 
201. MADEIRA, M.C.; TAKAHASHI, M.K.; CARVALHO, M.A. Unitermos ou palavras-chave nos artigos das revistas nacionais de odontologia. Revista de Odontologia da UNESP, 18: 335-40, 1989.

202. MAGRO FILHO, O.; MELO, M.S.; MARTIN, S.C. Métodos de esterilização, desinfecção e paramentação utilizados pelo cirurgião-dentista e auxiliar no consultório odontológico. Levantamento entre os profissionais. Revista da Associação Paulista de Cirurgiões-Dentistas, 45 (5): 589-92, 1991.

203. MAILART, D.; PEREIRA, M.F.; FREITAS, A. O valor da radiografia nas perícias odonto-legais. Revista da Associação Paulista de Cirurgiões-Dentistas, 45 (2): 443-6, 1991.

204. MANFREDINI, M.A.; SCHNEIDER, D.A.; NARVAI, P.C. Seriedade já. Saúde em Debate, 36: 95, 1992.

205. MARCOS, B. Reflexões a respeito do ensino. $R G O, 34$ (2): 186, 1986.

206. MARCOS, B. Sistemas de atenção em odontologia. Vias de acesso. Revista Paulista de Odontologia, 13 (5): 2-14, 1991.

207. MARINHO, L.A.C.; LISBOA, J.F.; SOUSA, S.M.G. Prevenção de doenças infecto-contagiosas em odontologia. Odontólogo Moderno, 16 (5): 6-15, 1989.

208. MAROTTI, M.; ALCÂNTARA, S.B. Influência da raça, sexo, idade e faixa salarial na experiência de cárie em indivíduos que procuraram o serviço de atendimento odontológico da FO/UFRGS. Revista da Faculdade de Odontologia de Porto Alegre, 28/29: 41-7, 1989.

209. MARQUES, A.L.; BARBOSA, C.M.R.; BARBOSA, J.R.A. A odontologia dentro do contexto "saúde no Brasil". Odontólogo Moderno, 12 (3): 7-15, 1990.

210. MARQUES, A.L.; BARBOSA, C.M.R.; BARBOSA, J.R.A. Estudo em população adulta da relação entre incidência de cáries e os nutrientes $\mathrm{Ca}, \mathrm{P}$, vitamina $\mathrm{C} \mathrm{e}$ proteínas. Odontólogo Moderno, 16 (1/2): 7-13, 1989. 
211. MARTILDES, M.L.R.; CASTELLANOS, R.A.; ROBLES, L.P. Prevalência de má oclusão em escolares de 12 anos de idade de São José dos Campos, SP, 1991. Revista Brasileira de Saúde Escolar, 3 (3/4): 112-6, 1993.

212. MARTILDES, M.L.R.; NARVAI, P.C.; MARTINS, J.A.M. Cárie dental: sistema incremental de atendimento e redução das necessidades de tratamento em escolares de três cidades do Ceará, entre 1979 e 1991. Revista Brasileira de Saúde Escolar, 2 (1): 11-8, 1992.

213. MARTILDES, M.L.R.; ROSA, A.G.F.; SILVA, N.N. Avaliação do impacto de programas incrementais sobre a prevalência de cárie dental em escolares. Revista Brasileira de Saride Escolar, 2 (2): 73-8, 1992.

214. MARTIN, L.M.A.Z. et al. Efeito do cloreto de cetilpiridínio sobre a formação e o metabolismo da placa dentária humana. Revista de Odontologia da USP, 4 (2): 108-12, 1990.

215. MARTINS, A.M.A.O.; VIGGIANO, R.D.; HALLA, D. Gengivite em crianças: prevalência e severidade na faixa etária de 3 a 6 anos de idade, em ambos os sexos. $R G O, 36$ (2): 141-5, 1988.

216. MATOS, F.G. O título de um trabalho científico: claro, conciso, concreto e criativo. Ciência e Cultura, 40 (8): 778-9, 1988.

217. MEDEIROS, U.V. Controle da placa bacteriana em saúde pública. Revista da Associação Paulista de Cirurgiões-Dentistas, 45 (3): 479-83, 1991.

218. MEDEIROS, U.V. Percepção da necessidade de saúde bucal pela comunidade. Revista da Associação Paulista de Cirurgiões-Dentistas, 43 (3): 120-4, 1989.

219. MEDEIROS, U.V.; CARVALHO, J.C.C. Estudo sobre as condições de saúde bucal da população: programa comunitário de atenção periodontal. Revista da Associação Paulista de Cirurgiões-Dentistas, 44 (3): 165-70, 1990.

220. MEDEIROS, U.V.; PARAIZO, C.A. Epidemiologia da cárie dentária em escolares do Estado do Rio de Janeiro. Revista Brasileira de Odontologia, 47 (6): 23-8, 1990 . 
221. MELLO, M.S.; FERREIRA, E.F.; PAIXÃO, H.H. Educação para a saúde em hospital: relato de uma experiência. Arquivos do Centro de Estudos do Curso de Odontologia da UFMG, 29 (2): 99-104, 1992.

222. MELO, M.M.D.C.; BRITO, S.A.F. Educação popular em odontologia. Saúde em Debate, 18: 30-1, 1986.

223. MENDES, A.M.; BIJELLA, V.T.; MORAES, N. Produtividade dos alunos na clínica de odontopediatria do curso de odontologia da FOUERJ. Levantamento descritivo, topográfico e fotográfico da distribuição dos equipamentos e condições de trabalho. (Estudo operacional). Revista Paulista de Odontologia, 9 (4): $18-43,1987$.

224. MENDES, E.V. A reforma sanitária e a educação odontológica. Cadernos de Saúde Pública, 2 (4): 533-52, 1986.

225. MENEGUINI, R.; FONSECA, L. Índices alternativos de avaliação da produção científica em bioquímica no Brasil. Ciência e Cultura, 42 (9): 629-45, 1990.

226. MENEZES FILHO, J.F. Incidência de neoplasias BMF. RGO, 39 (6): 428-30, 1991.

227. MESTRINER JR, W. New trends in dentistry. Brazilian Dental Journal, 4 (2): 135-6, 1993.

228. MICHELI, G.; SARIAN, R. Placa bacteriana - controle químico: estudo clínico, em humanos, da eficiência de dois produtos, comparados com um placebo, quando utilizados na forma de bochechos imediatamente antes da higiene bucal (préescovação). Revista da Associação Paulista de Cirurgiões-Dentistas, 44 (6): 333-6, 1990.

229. MICHELI, G.; SARIAN, R.; CARVALHO, J.C.C. Recursos para o controle da placa bacteriana (Estudo comparativo em humanos). Revista da Associação Paulista de Cirurgiões-Dentistas, 40 (5): 346-52, 1986. 
230. MILANEZI, L.A. et al. Estudo sobre o comportamento de acadêmicos de odontologia em relação às soluções evidenciadoras de placa bacteriana. Odontólogo Moderno, 14 (1): 12-6, 1987.

231. MILANEZI, L.A. et al. Fio e fita dentais: estudo comparativo do método manual com e sem auxilio de suporte. Odontólogo Moderno, 20 (3): 25-7, 1993.

232. MILANEZI, L.A. et al. Fios e fitas dentais: estudo sobre a absorção. Odontólogo Moderno, 17 (10): 16-9, 1990.

233. MILANEZI, L.A. et al. Influência do tamanho da ponta ativa das escovas dentárias na limpeza dos dentes. Odontólogo Moderno, 20 (1): 19-22, 1993.

234. MINAYO, M.C.S. O desafio do conhecimento: pesquisa qualitativa em saúde. São Paulo-Rio de Janeiro, HUCITEC-ABRASCO, 1992.

235. MOIMAZ, S.A.S. et al. Saúde bucal e a professora de $1^{\circ}$ grau. $R G O, 40$ (4): 295-7, 1992.

236. MONDELLI, J.; BASTOS, M.T.A.A. Contaminação mercurial em odontologia. Odontólogo Moderno, 17 (6): 9-21, 1990.

237. MONTEIRO JR, S. Testes para determinar atividade de cárie. $R G O, 35$ (6): 427 $30,1987$.

238. MORAES, A.B.A.; GIL, I.A. Diretrizes para a compreensão do estresse do cirurgião-dentista. Revista da Associação Paulista de Cirurgiões-Dentistas, 46 (6): $931-5,1992$.

239. MORAES, S.; GRILLO, M.C.; MARTA JR, E.A. Prevalência de patologias sistêmicas ou condições especiais em pacientes odontológicos atendidos em pronto-socorro (análise de 2.000 atendimentos). Revista Brasileira de Odontologia, 50 (6): 32-5, 1993.

240. MORAES, S.; NAKONECHNYJ, P. Questionário de saúde. Sua importância e aplicação em odontologia. Revista Brasileira de Odontologia, 47 (1): 48-56, 1990 
241. MOREIRA, B.H.W.; OLIVEIRA, S.P. Integração docente-assistencial: análise dos resultados de um programa. $R G O, 35$ (4): 284-6, 1987

242. MOREIRA, B.H.W.; PRADO, S.O. Programa de integração docente-assistencial. II: análise dos resultados de 1985 e 1986. Revista Brasileira de Odontologia, 45 (3): 24-32, 1988.

243. MOREIRA, E.J.G.; NARESSI, W.G.; VANTINE, A.S. Bochechos fluoretados. Revista da Associação Paulista de Cirurgiões-Dentistas, 41 (1): 18-23, 1987.

244. MOREIRA, S.G.; HAHN, M.A. Importância de hábitos de higiene bucal em programas que visam a promoção de saúde. Odonto Ciência, 8 (15): 43-52, 1993.

245. MOREIRA, S.G.; HAHN, M.A.S. Considerações sobre o trabalho educativopreventivo a nível comunitário. Revista da Faculdade de Odontologia de Porto Alegre, 33 (1): 26-7, 1992.

246. MORITA, M.C.; WALTER, L.R.F.; GUILLAIN, M. The prevalence of dental caries in brazilian children aged 0 to 36 months. Revista Odontológica do Brasil Central, 2 (5): 17-9, 1992.

247. NAKAE, K. et al. Controle da placa bacteriana por meio da aplicação tópica de substância química. Revista da Associação Paulista de Cirurgiões-Dentistas, 40 (4): $282-4,1986$.

248. NARESSI, S.C.M.; NARESSI, W.G. Estudo comparativo de produtividade entre alunos, trabalhando sós e auxiliados, em laboratório clínico. Revista Brasileira de Odontologia, 49 (2): 44-7, 1992.

249. NARESSI, W.G.; NARESSI, S.C.M. Aspectos ergonômicos da prática odontológica na cidade de São José dos Campos (SP) - Análise do ambiente fisico de trabalho. Revista de Odontologia da UNESP, 22 (1): 145-54, 1993.

250. NARESSI, W.G.; NARESSI, S.C.M. Aspectos ergonômicos da prática odontológica na cidade de São José dos Campos (SP) - Análise da adequação de 
alguns elementos do equipamento. Revista de Odontologia da UNESP, 22 (2): 315-23, 1993.

251. NARVAI, P.C. Prática odontológica no Brasil: propostas e ações no período $1952-$ 92. São Paulo, 1993. [Dissertação de Mestrado - Faculdade de Saúde Pública, Universidade de São Paulo]. 184p.

252. NEDER, A.C.; MANFREDINI, M.A. Sobre a oportunidade de fluoretação do sal no Brasil: a modernidade do atraso. Saúde em Debate, 32: 72-4, 1991.

253. NORMANDO, A.D.C.; ARAÚJO, I.C. Prevalência de cárie dental em uma população de escolares da região amazônica. Revista de Saúde Pública, 24 (4): 294-9, 1990.

254. NUNES, L.S.L.; SLAVUTZKY, S.M.B. O papel do tabagismo na doença periodontal. Revista da Faculdade de Odontologia de Porto Alegre, 33 (1): 368, 1992.

255. OLIVEIRA, A.A.C. A escolha da profissão odontológica: motivação positiva e negativa. Odontólogo Moderno, 13 (4): 47-57, 1986.

256. OLIVEIRA, B.H. Cuba: a odontologia presente na revolução da saúde. $R G O, 37$ (5): $391-4,1989$.

257. OLIVEIRA, F.A.M.; CAMARGO NETO, E.S. Aspartame - perspectivas de um adoçante não cariogênico. Odonto Ciência, 1 (2): 24-8, 1986.

258. OLIVEIRA, G.C.R. et al. Higiene bucal orientada: avaliação da influência da escovação, na condição gengival de crianças fissuradas de lábio e/ou palato. $R G O, 40$ (6): 388-92, 1992.

259. OLIVEIRA, J.F. et al. Contribuição ao estudo do aleitamento materno: enfoque anticariogênico. Odontólogo Moderno, 17 (9): 6-9, 1990.

260. OLIVEIRA, M.F.J.; ALBUQUERQUE, A.J. Participação popular e prática odontológica em serviço público de saúde: uma experiência. Saúde em Debate, 37: 40-3, 1992. 
261. OLIVEIRA, M.G.; CROSSETTI, S.L. Situação de saúde bucal de alunos de $1^{\circ}$ ano da Faculdade de Odontologia da PUCRS: relacionamento de resultados dos exames clínicos e radiográficos. Odonto Ciência, 3 (5): 39-47, 1988.

262. OLIVEIRA, S.P.; MIRANDA, V.L.A.; MOREIRA, B.H.W. Programa integrado de educação e saúde escolar. $R G O, 34$ (3): 264-6, 1986.

263. OPPERMANN, R.V. et al. Análise de um modelo experimental de cárie "in vivo". Revista Brasileira de Odontologia, 46 (5): 18-23, 1989.

264. ORGANIZACION PAN-AMERICANA DE LA SALUD. Seminarios latinoamericanos sobre la enseñanza de la odontologia. Washington, DC, OPAS-OMS, 1965. Publicaciones científicas, no 121. 390p.

265. PAIVA, M.S. Cariogenicidade dos medicamentos: um risco à saúde bucal. $R G O, 39$ (5): 336-8, 1991.

266. PAIVA, S.M. et al. A fluorose dentária sob o ponto de vista de uma comunidade atingida. $R G O, 41$ (1): 57-8, 1993.

267. PAIVA, S.M. et al. Fluorose dentária severa. $R G O, 39$ (2): 109-10, 1991.

268. PAIVA, S.M.; GONÇALVES, D.H.A.; PÉRET, L.R.C.A. Promoção de saúde bucal: programa implantado em escolares da região leste de Belo Horizonte. Saúde em Debate, 37: 36-9, 1992.

269. PAIXÃO, H.H. Saúde e doença: um estudo de representação social. Arquivos do Centro de Estudos do Curso de Odontologia da UFMG, 23 (1/2): 9-17, 1986.

270. PARANHOS, H.F.O.; PARDINI, L.C..; PANZERI, H. Hábitos de higienização de portadores de prótese total. Revista Paulista de Odontologia, 13 (1): 11-21, 1991.

271. PAULA, A.A.G.; TOLEDO, O.A. Idade para aplicação do selante: erupção dos primeiros molares permanentes. Importância na elaboração de um programa de aplicação de selante de fóssulas e fissuras. $R G O, 40$ (2): 127-9, 1992.

272. PAVARINI, A.; GARIB, T.M. Prevenção de traumatismos buco-dentários. $R G O$, 41 (1): 41-4, 1993. 
273. PEIXOTO, E.M.C.; SILVA, M.F.A. Avaliação "in vitro" em humanos de um gel fluoretado para aplicações tópicas por um minuto. Revista Brasileira de Odontologia, 49 (2): 40-3, 1992.

274. PERA, R.V.; MORAES, N. Efeito da perda prematura de molares decíduos sobre a oclusão, medido pelo índice TPI de Grainger. Estomatologia e Cultura, 16 (3): $3-8,1986$.

275. PEREIRA, A.C.; MOREIRA, B.H.W. A utilização do auxiliar odontológico para o aumento da produtividade nos serviços públicos. Revista da Associação Paulista de Cirurgiões-Dentistas, 46 (5): 851-4, 1992.

276. PEREIRA, J.C.R.; SAES, S.G. Avaliação de estratégias de gestão de ciência e tecnologia: um estudo de caso. Revista de Saúde Pública, 29 (4): 308-17, 1995.

277. PEREIRA, O.L. Desgaste das cerdas das escovas: observação clínica em relação ao tempo de uso. $R G O, 40$ (4): 267-9, 1992.

278. PEREIRA, O.L. et al. Conhecimentos e hábitos de higiene bucal: avaliação em policiais militares de Araraquara/SP. RGO, 41 (2): 91-4, 1993.

279. PEREIRA, O.L. et al. Educação sobre higiene bucal e índice de placa: avaliação de um programa de motivação em policiais militares de Araraquara/SP. $R G O, \mathbf{4 0}$ (6): 421-2, 1992.

280. PERRONE, O. Pesquisa bibliográfica. Rio de Janeiro, Publicações Científicas, 1972.

281. PETERS, C.F.; GAVAZZI, J.C.C.; OLIVEIRA, S.F. Estudo da prevalência de mordidas cruzadas na dentição decídua: relação com hábitos de suç̧ão. Revista Paulista de Odontologia, 8 (2): 38-43, 1986. [Publicado também na Enciclopedia Brasileira de Odontologia, 5: 145-53, 1987.]

282. PINHEIRO, C.E. Efeito da associação cloreto de cetilpiridínio-fluoreto de sódio na fermentação e na síntese de polissacarídeos extracelulares insolúveis da placa dentária "in vitro". Revista Brasileira de Odontologia, 48 (1): 18-20, 1991. 
283. PINHEIRO, C.E.; PINHEIRO, C.F. Goma de mascar anticárie: ingredientes, avaliação e mecanismo de ação. Odontólogo Moderno, 19 (6): 19-22, 1992.

284. PINTO, E.J.; IACOBUCCI, F.; FICHMAN, D.M. Contaminação por mercúrio um levantamento do comportamento do cirurgião-dentista frente ao risco. Revista Paulista de Odontologia, 12 (3): 39-42, 1990.

285. PINTO, I.L. Prevenção da cárie dental com aplicações tópicas semestrais de flúorfosfato acidulado. Revista de Saúde Pública, 27 (4): 277-90, 1993.

286. PINTO, M.L.M.C. Educação sanitária. Revista da Faculdade de Odontologia da UFBA, 7: 95-102, 1987.

287. PINTO, M.L.M.C. Situação odontológica do idoso no Brasil. Revista da Faculdade de Odontologia da UFBA, 7: 23-8, 1987.

288. PINTO, V.G. A questão epidemiológica e a capacidade de resposta dos serviços de saúde bucal no Brasil. Brasilia, 1992. [Tese de Doutoramento - Faculdade de Saúde Pública, Universidade de São Paulo]. 217p.

289. PINTO, V.G. A síndrome da prótese total. $R G O, 39$ (5): 394, 1991.

290. PINTO, V.G. Relacionamento entre padrões de doença e serviços de atenção odontológica. Revista de Saúde Pública, 23 (6): 509-14, 1989.

291. PINTO, V.G. Revisão sobre o uso e segurança do flủor. $R G O, 41$ (5): 263-6, 1993.

292. PINTO, V.G. Saúde bucal: odontologia social e preventiva. 1a. ed. São Paulo, Santos, 1989. 415p.

293. PIRES FILHO, F.M. O que é saúde pública? Cadernos de Sanide Pública, 3 (1): 62-70, 1987.

294. PORTILLO, J.A.C. Relatório da experiência de saúde bucal em Itu. Saxide em Debate, 18: 11-4, 1986.

295. PRADO, I.A.T. et al. Estabilidade do flúor em amostras de água. $R G O, 40$ (3): 197-9, 1992. 
296. PRADO, M.C.P. et al. Estudo da microbiota do ar da clínica odontológica do Hospital Universitário da Faculdade de Odontologia da Universidade de São Paulo. Revista de Odontologia da USP, 4 (2): 97-102, 1990.

297. PRAMPERO, A.L. et al. Estudo da interação de escovas dentais de diferentes tipos de cerdas com preparações básicas para dentifrícios. $R G O, 40$ (4): 298-302, 1992.

298. QUIVY, R.; CAMPENHOUDT, L.V. Manual de investigação em ciências sociais. Lisboa, Gradiva, 1992.

299. RAMOS, P.A.V.; BECKER, R.V. Selantes em saúde pública: aplicação de selante em clínica de odontologia pública. $R G O, 35$ (2): 160-2, 1987.

300. REIS, I.T.; MOREIRA, S.C. Risco de cárie em bebês. Revista Odontológica do Brasil Central, 5 (14): 11-7, 1995.

301. REQUEJO, M.E.P.; VIANNA, A.W.C.; VIANNA, R.B.C. A utilização do selante de sulcos e fissuras na prevenção da cárie dentária. Revista Brasileira de Odontologia, 44 (2): 54-62, 1987.

302. RIBEIRO, H. Flúor - análise de teor em água fervida. $R G O, 40$ (1): 59-61, 1992.

303. RICCI, A.; BIJELLA, V.T. Doenças infecciosas e parasitárias em odontologia: riscos de contágio. Odontólogo Moderno, 16 (8): 7-21, 1989.

304. ROBINSON, L.C. Análise numérica da produção técnico-científica do CBPF publicada em periódicos brasileiros e estrangeiros no período de 1981 a 1985. Ciência e Cultura, 41 (3): 259-63, 1989.

305. ROCCHI, V.A.A.P. et al. Fluoretação e saúde gengival. $R G O, 39$ (3): 228-30, 1991.

306. ROCHA, A.C.T.; RAMALHO, L.M.P.; SANTANA, E.J.B. Prevalência das neoplasias de glândulas salivares na cidade de Salvador, Estado da Bahia, Brasil. Revista da Faculdade de Odontologia da UFBA, 12/13: 61-81, 1992/1993.

307. ROCHI, V.A.A.P. et al. Eficiência do selante autopolimerizável: período de retenção e efeito na prevenção da cárie dentária. $R G O, 37$ (6): 475-9, 1989. 
308. RODRIGUES, C.R.M.D.; ANDO, T.; GUIMARÃES, L.O.C. Simplificação do indice gengival, nas idades de 4 a 6 e de 7 a 10 anos (dentições decídua e mista). Revista de Odontologia da USP, 3 (3): 414-9, 1989.

309. RODRIGUES, C.R.M.D.; ANDO, T.; GUIMARÃES, L.O.C. Simplificação do índice de cárie nas idades de 4 a 6 e de 7 a 10 anos (dentições decídua e mista). Revista de Odontologia da USP, 3 (4): 454-9, 1989.

310. RODRIGUES, C.R.M.D.; ANDO, T.; GUIMARÃES, L.O.C. Simplificação do indice da higiene bucal nas idades de 4 a 6 e de 7 a 10 anos (dentições decídua e mista). Revista de Odontologia da USP, 4 (1): 20-4, 1990.

311. RODRIGUES, C.R.M.D.; OLIVEIRA, M.M.; ANDO, T. Cariostático - diaminofluoreto de prata. Revista da Associação Paulista de Cirurgiões-Dentistas, 43 (4): 171-4, 1989

312. ROSA, A.G.F. et al. Condições de saúde bucal em pessoas de 60 anos ou mais no município de São Paulo (Brasil). Revista de Saúde Pública, 26 (3): 155-60, 1992.

313. ROSA, A.G.F.; CASTELLANOS, R.A.; PINTO, V.G. Saúde bucal na terceira idade: um diagnóstico epidemiológico. RGO, 41 (2): 97-102, 1993.

314. ROSA. A.G.F.; MARTILDES, M.L.R.; NARVAI, P.C. Programa de reorientação do atendimento odontológico escolar com ênfase na prevenção: análise da prevalência da cárie dental em escolares de 7 a 14 anos, matriculados nas escolas municipais de São José dos Campos, SP, em 1979, 1985 e 1991. RGO, 40 (2): $110-4,1992$.

315. ROSIELLO, A.S.; OLIVEIRA, E.; ROSIELLO, S.L. Elementos traços e sua aplicação em odontologia preventiva. Revista Paulista de Odontologia, 13 (2): 2-6, 1991.

316. ROSIELLO, A.S.; ROSIELLO, S.L. Selantes oclusais: ação sobre cáries incipientes. Revista Paulista de Odontologia, 11 (1): 4-10, 1989. 
317. ROSING, C.K.; PESCININI, L.M.; PEREIRA, O.L. Participação do técnico em higiene dental na prática odontológica. Odontólogo Moderno, 20 (6): 27-8, 1993.

318. ROSSA JR, C.; MARCANTONIO, R.A.C. AIDS e o cirurgião-dentista: manifestações clínicas e prevenção. $R G O, 39$ (4): 265-70, 1990.

319. ROSSETINI, S.M.O.; NARESSI, W.G. Exercício profissional do cirurgiãodentista: quando e onde mais trabalha o clínico particular. $R G O, 34$ (4): 303-5, 1986.

320. SABA-CHUJFI, E. et al. Algumas considerações sobre a epidemiologia da doença periodontal. Revista Paulista de Odontologia, 11 (6): 10-6, 1989.

321. SABA-CHUJFI, E. et al. Avaliação de diferentes métodos de motivação à higiene bucal aplicados em crianças de 7 a 12 anos de idade. Revista da Associação Paulista de Cirurgiões-Dentistas, 43 (1): 13-5, 1989.

322. SABA-CHUJFI, E. et al. Avaliação dos métodos de motivação/educação em higiene bucal. $R G O, 40$ (2): 87-90, 1992.

323. SALGADO, P.E.T. et al. Risco ocupacional ao mercúrio na odontologia. $R G O, 35$ (3): 183-7, 1987.

324. SALVADOR, A.D. Métodos e técnicas de pesquisa bibliográfica: elaboração e relatório de estudos científicos . 2a.ed. Porto Alegre, Sulina, 1970.

325. SAMPAIO, L.A.; BARBOSA, C.E.M.; CAMPAIO, J.E.C. Recomendações para o trabalho em clínicas e consultórios odontológicos, visando proteção frente às doenças virais - AIDS, hepatite B e outras. Parte 2. Odontólogo Moderno, 20 (6): 23-6, 1993.

326. SANDER, R.; BELLINI, L. Cárie de mamadeira: quadro generalizado de lesões cariosas agudas. Odonto Ciência, 2 (4): 40-6, 1987.

327. SANTOS, G.M.C.; BOTTI, M.R. Perspectivas do exercício profissional: uma análise efetuada por formandos de odontologia - Parte II: a pós-graduação. $R G O, 35$ (3): 225-6, 1987. 
328. SANTOS, N.P.; ANDO, T. Cáries em molares decíduos de crianças residentes em região com alto teor de flúor na água e em área carente do mesmo halogênio. Enciclopedia Brasileira de Odontologia, 6: 167-74, 1988.

329. SANTOS, V.I.M. et al. Índice de indutos, em dentes decíduos de crianças de 4 a 6 anos. Revista Paulista de Odontologia, 9 (5): 18-27, 1987.

330. SAQUY, P.C. Algumas características de aparelhos mais usados por cirurgiõesdentistas de Ribeirão Preto em seus consultórios. Revista Paulista de Odontologia, 15 (3): 18-20, 1993.

331. SAQUY, P.C. et al. O código de defesa do consumidor e o cirurgião-dentista. Revista Paulista de Odontologia, 15 (4): 4-5, 1993.

332. SAQUY, P.C.; PECORA, J.D.; SAVIOLI, R.N. Formas de prevenção contra doenças contagiosas adotadas pelos cirurgiões-dentistas de Ribeirão Preto em seus consultórios. Odontólogo Moderno, 17 (7): 10-2, 1990.

333. SAQUY, P.C.; SOUSA NETO, M.D.; PÉCORA, J.D. Sistema de dois consultórios amplia a clientela e as chances no mercado de trabalho. Odontólogo Moderno, 20 (2): 19-20, 1993.

334. SCARPA, W.B. Efeito da higiene oral sobre a placa bacteriana. $R G O, 38$ (5): 358$68,1990$.

335. SERPENTINO, A.H. et al. Formação da placa dentária in vitro por açúcar mascavo. Revista de Odontologia da USP, 2 (4): 213-7, 1988.

336. SERRA, M.C.; CURY, J.A. Cinética do flúor na saliva após o uso de dentifrício e bochecho fluoretados. Revista da Associação Paulista de Cirurgiōes-Dentistas, 46 (5): 875-8, 1992.

337. SILVA FILHO, C.F. A racionalidade da fluoretação do açúcar no Brasil: uma proposta baseada no mecanismo de ação do flúor no papel do açúcar na etiologia da cárie e na realidade brasileira. Revista da Associação Paulista de CirurgiõesDentistas, 46 (6): 915-9, 1992. 
338. SILVA FILHO, O.G.; FREITAS, S.F.; CAVASSAN, A.O. Prevalência de oclusão normal e má oclusão na dentadura mista em escolares da cidade de Bauru (São Paulo). Revista da Associação Paulista de Cirurgiões-Dentistas, 43 (6): 287-90, 1989.

339. SILVA FILHO, O.G.; FREITAS, S.F.; CAVASSAN, A.O. Prevalência de oclusão normal e má oclusão em escolares da cidade de Bauru (São Paulo). Parte I: relação sagital. Revista de Odontologia da USP, 4 (2): 130-7, 1990.

340. SILVA FILHO, O.G.; FREITAS, S.F.; CAVASSAN, A.O. Prevalência de oclusão normal e má oclusão em escolares da cidade de Bauru (São Paulo). Parte II: influência da estratificação sócio-econômica. Revista de Odontologia da USP, 4 (3): 189-96, 1990.

341. SILVA FILHO, O.G.S.; FREITAS, S.F.; CAVASSAN, A.O. Hábitos de sucção. Elementos passiveis de intervenção. Estomatologia e Cultura, 16 (4): 61-71, 1986.

342. SILVA JR, M.S.; SEIXAS, A.S.S.; SILVA, L.T.G. Consultório odontológico uma via de transmissão microbiana. Revista da Associação Paulista de Cirurgiões-Dentistas, 42 (2): 153-4, 1988.

343. SILVA NETTO, C.R. Experiência de atendimento voluntário odontológico em centro comunitário. Revista Brasileira de Odontologia, 44 (3): 42-6, 1987.

344. SILVA NETTO, C.R.; GUIMARÃES, A.C.A.C. Alívio da dor: um fator de procura do setor odontológico em centro comunitário. Odontólogo Moderno, 17 (4): 19-22, 1990.

345. SILVA, B.B.; ROSSONI, E. Diagnóstico clínico da doença cárie. Revista da Faculdade de Odontologia de Porto Alegre, 33 (1): 12-7, 1992.

346. SILVA, J. Reivindicar é o papel do sindicato. Saúde em Debate, 18: 34-5, 1986.

347. SILVA, M. Estimativa da estatura do indivíduo com a utilização de um grupo de dentes da mandíbula. Revista Paulista de Odontologia, 12 (4): 18-28, 1990. 
348. SILVA, M.F.A. Flúor na placa dental: formas e ação sobre a produção ácida. $R G O$, 34 (3): 199-202, 1986.

349. SILVA, M.F.A. Flúor: existem razões para controvérsia? $R G O, 35$ (3): 195-8, 1987.

350. SILVA, M.F.A. O problema da fluoretação do sal no Brasil. $R G O, 39$ (4): 306-8, 1991

351. SILVA, M.V.M.; NOVAES JR, A.B.; NOVAES, A.B. Avaliação dos hábitos de higiene em clínica particular - 500 pacientes. Revista Brasileira de Odontologia, 47 (1): 12-8, 1990.

352. SILVA, R.C. Odontologia social: panorama da saúde bucal no Acre - a edentação preocupa. Odontólogo Moderno, 20 (1): 6-8, 1993.

353. SILVA, R.C. Saúde bucal em escolares do Acre. $R G O, 41$ (2): 110-2, 1993.

354. SILVA-NETTO, C.R.; SILVA, E.M.C. Atividade extramuros com estudantes de odontologia - Voluntários: Análise de seis anos. Odontólogo Moderno, 14 (10): 33-6, 1987.

355. SILVEIRA, R.S.; FIGLIOLI, M.D. Ergonomia aplicada à dentística: trabalho a quatro mãos em restaurações classes I, II e III - Parte 1. Odontólogo Moderno, 20 (5): 13-9, 1993.

356. SIMÕES, W.; VILLI, E.R.; SILVA, M. Correlação entre o comprimento total dos dentes incisivos centrais superiores permanentes com suas coroas e com a alturalargura da face, nos tipos faciais de leucodermas brasileiros. Revista de Odontologia da USP, 2 (3): 148-52, 1988.

357. SIMONATO, C.A.S.; PINTO, A.C.G.; SANTOS, N.P. Uso clínico dos vernizes com flúor Duraphat e Flúor Protector. Enciclopedia Brasileira de Odontologia, 5: $161-8,1987$.

358. SLAVUTZKY, S.M.B.; BERCHT, S.; LIMA, L.S. Perfil do calouro odontologia. Revista da Faculdade de Odontologia de Porto Alegre, 33 (2): 13-5, 1992. 
359. SOUSA, M.L.R et al. Análise de algumas variáveis clínicas em relação aos níveis salivares de S. mutans. Revista de Odontologia da USP, 6 (3/4): 169-73, 1992.

360. SOUZA, E.S. et al. Diagnóstico de saúde da área de atuação da Unidade de Odontologia Social e Preventiva da Universidade Federal de Uberlândia: prevalência da cárie dentária em escolares da rede oficial de ensino de Uberlândia-MG. Enciclopedia Brasileira de Odontologia, 5: 701-9, 1987.

361. SOUZA, M.M.; CORREA, A.P. Influência da profilaxia na retenção de selantes. Revista da Faculdade de Odontologia da UFBA, 12/13: 106-12, 1992/1993.

362. SPADARO, A.C. et al. Avaliação do teor de fluoreto na água de abastecimento de cidades na região de Ribeirão Preto. Revista de Odontologia da USP, 4 (3): 252$5,1990$.

363. SPERANÇA, P.A.; TELES, G.S. Avaliação das soluções bucais pré-escovação: estudo microbiológico in vitro. $R G O, 39$ (6): 407-10, 1991.

364. SPÍNOLA, A.W.P. et al. Pesquisa social em saúde. São Paulo, Cortez, 1992.

365. SPYRIDES, G.M. et al. Uma nova abordagem na clínica odontológica. A saúde holistica. Revista Brasileira de Odontologia, 50 (6): 14-7, 1993.

366. SUNDEFELD, M.L.M.M.; SALIBA, O.; SALIBA, N.A. Estudo descritivo da ocorrência do câncer da boca, na população da $9^{a}$ Região Administrativa do Estado de São Paulo. Revista de Odontologia da UNESP, 22 (1): 135-45, 1993.

367. SUSIN, A.H.; PEREIRA, O.L. Atendimento preventivo em consultório e orientação continuada. Uma solução ao nosso alcance. Revista Odontológica do Brasil Central, 3 (7): 33-4, 1993.

368. TAGUCHI, M.F. et al. O medo frente ao tratamento odontológico. $R G O, 41$ (3): 138-42, 1993.

369. TAVARES, S.S.; SILVA, H.C.; SILVA, R.H.H. Avaliação do grau de retenção de selantes de fóssulas e fissuras em 3 diferentes condições. $R G O, 35$ (2): 91-4, 1987. 
370. TEIXEIRA, R.N. et al. Fluoretação do sal de cozinha: II - Preparo do sal a nível familiar. Revista Brasileira de Odontologia, 43 (3): 4-6, 1986.

371. TEIXEIRA, R.N.; CURY, J.A. Reatividade dos dentifrícios fluoretados comercializados no Brasil com o esmalte dental humano. $R G O, \mathbf{3 4}$ (5): 381-3, 1986.

372. TEODORO FILHO, I.; GALVÃO, C.A.A.N. Ginástica para os CDs. Enciclopedia Brasileira de Odontologia, 5: 679-91, 1987.

373. TODESCAN, J.H. Prevenção: usos e costumes da higiene bucal - III. Revista da Associação Paulista de Cirurgiões-Dentistas, 45 (6): 641-3, 1991.

374. TODESCAN, J.H. Usos e costumes da higiene bucal - II. Revista da Associação Paulista de Cirurgiões-Dentistas, 45 (5): 593-6, 1991.

375. TODESCAN, J.H.; LIMA, L.A.P.A.; TODESCAN, C.G. Escovas com cerdas de pontas arredondadas: uma verdade científica ou uma realidade prática? Revista da Associação Paulista de Cirurgiões-Dentistas, 43 (1): 31-3, 1989.

376. TODESCAN, J.H.; SIMA, F.T. Campanhas de prevenção e orientação para com a higiene bucal: prevenção - usos e costumes da higiene bucal - I. Revista da Associação Paulista de Cirurgiões-Dentistas, 45 (4): 537-9, 1991.

377. TOLEDO, O.A. et al. Prevalência da cárie dentária relacionada com o estado nutricional em população de baixa renda do Distrito Federal. $R G O, 37$ (4): 295 $8,1989$.

378. TORRES, I.A. Câncer de boca no Brasil - perfil atual do odontólogo frente ao problema. Saúde em Debate, 37: 44-7, 1992.

379. TREVISAN, E.A.S. et al. Estudo clínico do comportamento de técnicas de escovação dental, do fio dental e suas associações, sobre as condições gengivais. Revista Brasileira de Odontologia, 48 (4): 46-52, 1991.

380. UCHÔA, H. et al. Fluoração do sal de consumo humano no Município de Cabo Frio (RJ). Revista Brasileira de Odontologia, 50 (2): 49-56, 1993. 
381. USBERTI, A.C.; RENCI, J.; PASSOS, J.M. Retenção dos selantes: avaliação de duas técnicas de aplicação. RGO, 39 (6): 465-7, 1991.

382. VALSECKI JR, A.; VERTUAN, V. Eficácia da associação de uma solução précondicionadora do esmalte (DCPD) e uma solução de flúor (FFA 0,5\% F), na prevenção da cárie dentária. $R G O, 39$ (6): 456-64, 1991.

383. VALSECKI JR, A.; VERTUAN, V. Retenção e eficácia do selante associado à aplicação tópica de flúor-fosfato-acidulado. $R G O, 36$ (5): 381-8, 1988.

384. VANTINE, P.I.; NARESSI, W.G. Utilização da higienista dental no serviço público do município de São José dos Campos-SP. Odontólogo Moderno, 19 (1): 13-15, 1992.

385. VASCONCELLOS, M.C.C. et al. Experiência de cárie dentária em escolares: o papel da ocupação da mãe. Revista de Odontologia da USP, 7 (4): 237-43, 1993.

386. VASCONCELLOS, M.C.C. et al. O programa de saúde bucal para crianças préescolares em Araraquara-SP: o desempenho em 1988. Revista de Odontologia da UNESP, 19: 283-9, 1990.

387. VASCONCELLOS, M.C.C. et al. O programa de saúde bucal para crianças préescolares em Araraquara-SP. Revista de Odontologia da UNESP, 17 (1/2): 1916,1988 .

388. VASCONCELLOS, M.C.C.; AMARAL, J.S. A sociedade brasileira e a prevenção em saúde bucal. Revista de Odontologia da USP, 6 (3/4): 133-9, 1992.

389. VASCONCELLOS, M.C.C.; SILVA, S.R.C. Distribuição de cárie dentária na dentição permanente de escolares, em Araraquara-SP. Revista de Odontologia da USP, 6 (1): 61-5, 1992.

390. VASCONCELLOS, M.C.C.; SILVEIRA, F. O conhecimento sobre a manutenção da própria saúde bucal em população que demanda centro de saúde. Revista de Odontologia da UNESP, 18: 225-31, 1989. 
391. VASCONCELLOS, P.P.; MORA, R.E.V.; ANGULO, N.G.C. Higiene oral. Revista Brasileira de Odontologia, 44 (5): 2-8, 1987.

392. VEECK, E.B. et al. Estudo epidemiológico dos carcinomas espinocelulares na cavidade bucal. Odonto Ciência, 7 (14): 25-34, 1992.

393. VELHO, L. Avaliação acadêmica. A hora e a vez do "baixo clero". Ciência e Cultura, 41 (10): 957-68, 1989.

394. VERTUAN, V. Redução de cáries com água fluoretada: após 19 anos de fluoretação das águas de abastecimento de Araraquara - São Paulo - Brasil. $R G O, 34$ (6): 469-71, 1986.

395. VERTUAN, V.; DINI, E.L. Selantes na prevenção da cárie. RGO, 35 (2): 130-7, 1987.

396. VIANNA, M.I.P. Emergência das políticas de saúde bucal no Brasil: uma análise do período 1923-1973. Revista da Faculdade de Odontologia da UFBA, 8-9: 28$49,1988 / 1989$.

397. VIANNA, M.I.P.; SOUZA, M.B.B.A. Estrutura de prestação de serviços do setor público em odontologia no Município de Salvador: um diagnóstico tendo em vista as ações integradas de saúde. Revista da Faculdade de Odontologia da UFBA, 6: 102-29, 1986.

398. VIANNA, R.B.C.; ARITA, E.S. Desempenho lógico em odontologia. $2^{\text {a }}$ parte. Revista Brasileira de Odontologia, 47 (3): 19-24, 1990.

399. VIANNA, R.B.C.; ARITA, E.S. Desempenho lógico. Revista Brasileira de Odontologia, 46 (4): 27-31, 1989.

400. VIANNA, S.M. A situação da pesquisa em saúde oral no Brasil. Brasília, IPEA/SPPR, 1987.

401. VIDIGAL JR, G.M.; BASTOS, W.R.; CHEVITARESE, O. Análise dos níveis de mercúrio em cabelo de estudantes de odontologia da UFRJ por espectrofotometria de absorção atômica. Revista Brasileira de Odontologia, 48 (5): 10-5, 1991. 
402. VIEGAS, A.R. Estudos operacionais sobre métodos preventivos em programas de odontologia em saúde pública. Revista da Associação Paulista de CirurgiõesDentistas, 46 (1): 677-80, 1992.

403. VIEGAS, A.R. et al. Fluoretação da água de abastecimento público. Revista da Associação Paulista de Cirurgiões-Dentistas, 41 (4): 202-4, 1987.

404. VIEGAS, A.R. Selantes em saúde pública. $R G O, 37$ (2): 117-20, 1989.

405. VIEGAS, Y.; VIEGAS, A.R. Prevalência de cárie dental em Barretos, SP, Brasil, após dezesseis anos de fluoretação da água de abastecimento público. Revista de Saúde Pública, 22 (1): 25-35, 1988.

406. VIEIRA, R.S. et al. Prevalência das afeç̧ões periodontais e de higiene bucal em crianças de 03 a 06 anos de idade. Enciclopedia Brasileira de Odontologia, 6 : 77-81, 1988.

407. VINHA, D.; VALE, L.V. Programa de profilaxia e prevenção da placa dental em uma população adulta. Revista Paulista de Odontologia, 9 (3): 2-14, 1987.

408. VINHA, P.P. et al. O uso do fio dental junto ao público. Revista Paulista de Odontologia, 15 (2): 38-42, 1993.

409. VOLSCHAN, B.C.G.; UZEDA, M. Cárie dentária assimétrica: relato de caso clínico. Revista Brasileira de Odontologia, 50 (6): 57-9, 1993.

410. VONO, A.Z. et al. Influência de bochechos com cepacol sobre a placa dentária. Parte I - Avaliação da quantidade de placa formada. $R G O, 38$ (5): 375-8, 1990.

411. WALTER, L.R.F. et al. Cárie em crianças de 0 a 30 meses de idade e sua relação com hábitos alimentares. Enciclopedia Brasileira de Odontologia, 5: 129-36, 1987.

412. WAMBIER, D.S.; PINTO, A.C.G.; MATSON, E. Número de movimentos da escova necessários para remoção da placa. $R G O, 36$ (4): 265-72, 1988.

413. WENDEL, M.T.S. et al. Influência do oxalato de cálcio e do carbonato de cálcio na incidência de cárie dentária em ratos. Estomatologia e Cultura, 16 (3): 34-7, 1986. 
414. WERNER, C. O controle inglês. $R G O, 37$ (6): 486, 1989.

415. WEYNE, S. Curso para atualização e educação continuada em odontologia preventiva (cariologia). Método para prevenção da cárie (III): uso de flúor. Revista Brasileira de Odontologia, 44 (1): 52-62, 1987.

416. WITT, M.C.R. et al. Estudo comparativo de duas gomas de mascar: efeito sobre a formação de placa dental in vivo. $R G O, 34$ (2): 180-2, 1986.

417. YABRUDY, M.L.A.; OLIVEIRA FILHO, J.B.; SANTOS, R.A. Saúde bucal dos pacientes diabéticos: análise comparativa dos índices $\mathrm{CPO}$, higiene oral $\mathrm{e}$ periodontal. $R G O, 41$ (2): 105-9, 1993.

418. ZAMORANO, W.M.C.; PARREIRA, M.L.J.; RIBEIRO, J.C.C. Estudo comparativo da prevalência de lesão cariosa em dentes permanentes, com variações do teor de flúor na água de abastecimento público, nas cidades de Belo Horizonte e Rio Acima-MG. Arquivos do Centro de Estudos do Curso de Odontologia da UFMG, 24 (1/2): 51-62, 1987.

419. ZANCANARO, M.A.; YURGEL, L.S.; LORANDI, C.S. Estudo epidemiológico de cem casos de carcinoma espinocelular de boca e orofaringe. Odonto Ciência, 1 (2): 57-62, 1986. 


\section{ANEXO 1 \\ PRODUÇÃO CIENTÍFICA NA ÁREA DE OPS NO BRASIL ARTIGOS PUBLICADOS EM PERIÓDICOS BRASILEIROS - PERÍODO 1986-1993}

Formulário número

?ferência do Artigo:

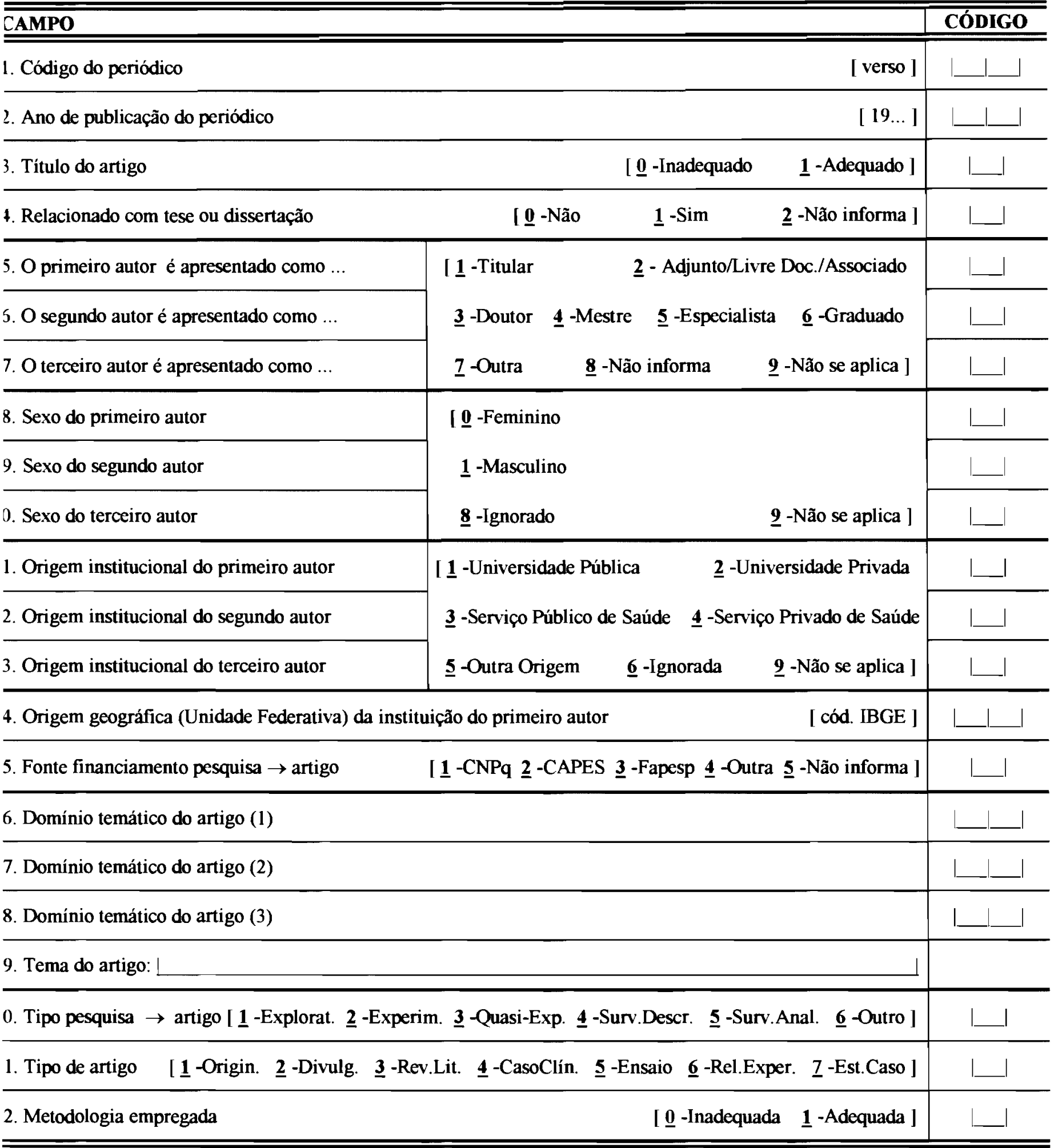


IDS, MANIFESTAÇOES CLINICAS NA CAV BUCAL E PREVENÇAO

SSISTENCIA ODONTOLOGICA EM CENTRO COMUNITARIO

SSISTENCIA ODONTOLOGICA, ASPECTOS PSICOLOGICOS

SSISTENCIA ODONTOLOGICA, AUTISTAS

SSISTENCIA ODONTOLOGICA, CAUSA DE ABSENTEISMO

SSISTENCIA ODONTOLOGICA, CAUSAS DE DEMANDA AOS SERVIÇOS

SSISTENCIA ODONTOLOGICA, CRESCIMENTO DE CONSULT PARTICULAR

ISISTENCIA ODONTOLOGICA, IDOSO

ISISTENCIA ODONTOLOGICA, MEDO

ISISTENCIA ODONTOLOGICA, PACIENTES ESPECIAIS

ISISTENCIA ODONTOLOGICA, RELAÇAO COM PADROES DOENÇAS BUCAIS ISISTENCIA ODONTOLOGICA, TECNICA ANTI RECUSA DE CRIANÇAS

IESTADO ODONTOLOGICO, ASPECTOS LEGAIS

[F, PREVENÇAO DE CARIE

[F, TECNICA DE APLICAÇAO

¿AO SINDICAL

3BE, AVALIAÇAO DE UM PROGRAMA ODONTOLOGICO

BBE, CARIE DE MAMADEIRA

BBE, HABITOS ALIMENTARES E CARIE

BBE, PROVIMENTO DE CUIDADOS ODONTOLOGICOS

:OSSEGURANÇA, PRATICA ENTRE CD

OSSEGURANÇA, TEMPERATURA DE ESTUFAS

INCER BUCAL, PROGRAMA DE PREVENÇAO E DETECÇAO PRECOCE

IRIE RADICULAR, PREVALENCIA E PREVENÇAO EM ADULTOS

RIE, DIAG COM EX CLINICOS E RADIOGRAFICOS EM ESTUDANTES

RIE, DIAGNOSTICO CLINICO

RIE, PREVALENCIA E ESTADO NUTRICIONAL

RIE, PREVALENCIA E ESTADO NUTRICIONAL EM POP DE BAIXA REND

RIE, PREVENÇAO EM PROGRAMAS DE SAUDE PUBLICA

RIE, TESTES DE ATIVIDADE

RIOGENICIDADE, ALEITAMENTO MATERNO E ENFOQUE NAO-CARIOGEN

RIOGENICIDADE, ASPARTAME ADOÇANTE NAO-CARIOGENICO

RIOGENICIDADE, MEDICAMENTOS

RIOGENICIDADE, MERENDA ESCOLAR

DADANIA E SAUDE BUCAL

DADANIA, SUS E SAUDE BUCAL

NTIFRICIOS, AÇAO ANTIMICROBIANA DO FLUOR

NTIFRICIOS, CONTAMINAÇAO METALICA

NTIFRICIOS, EFICACIA COM XILITOL E OU FLUOR

NTIFRICIOS, EFICACIA NA LIMPEZA DE PROTESES TOTAIS

NTIFRICIOS, ESTABILIDADE DO FLUOR

NTIFRICIOS, FLUOR

NTIFRICIOS, PRESENÇA DE FLUOR E REATIVIDADE COM ESMALTE

NTIFRICIOS, REATIVIDADE DO FLUOR, RELAÇAO Ca:MFP

PENDENCIA FISICA DE DROGAS, LEGISLAÇAO

AMINO FLUORETO DE PRATA, CARIOSTATICO

ONOMIA PROFISSIONAL

ONOMIA PROFISSIONAL, CALCULO DE HONORARIOS NO COMPUTADOR

ONOMIA PROFISSIONAL, CONCORRENCIA
$0.3 \%$

$0.3 \frac{9}{8}$

$0.3 \frac{9}{8}$

$0.3 \frac{8}{8}$

$0.3 \%$

$0.3 \%$

$0.3 \%$

$0.3 \%$

$0.3 \%$

$0.3 \%$

$0.3 \%$

$0.3 \%$

$0.3 \%$

$0.3 \%$

$0.3 \%$

$0.3 \%$

$0.3 \%$

$0.3 \%$

$0.3 \%$

$0.3 \%$

$0.3 \%$

$0.3 \%$

$0.3 \%$

$0.3 \%$

$0.3 \%$

$0.3 \%$

$0.3 \frac{8}{8}$

$0.3 \%$

$0.3 \%$

$0.5 \%$

$0.3 \%$

$0.3 \%$

$0.3 \%$

$0.3 \%$

$0.3 \%$

$0.3 \frac{9}{8}$

$0.3 \%$

$0.3 \%$

$0.3 \%$

$0.3 \%$

$0.3 \%$

$0.8 \%$

$0.3 \%$

$0.3 \%$

$0.3 \%$

$0.5 \%$

$0.5 \%$

$0.3 \%$

$0.3 \%$ 
CONOMIA PROFISSIONAL, PREÇOS

DUCAÇAO EM SAUDE

DUCAÇAO EM SAUDE BUCAL

DUCAÇAO EM SAUDE EM HOSPITAL

DUCAÇAO EM SAUDE NA ESCOLA, EPI CARIE

DUCAÇAO EM SAUDE, AÇAO NA COMUNIDADE

DUCAÇAO EM SAUDE, CONHECIMENTOS DE PROF DE PRIMEIRO GRAU DUCAÇAO EM SAUDE, PROGRAMA DE PREVENÇAO

NSINO ODONTOLOGICO

NSINO ODONTOLOGICO, ATIVIDADES EXTRA-MUROS

NSINO ODONTOLOGICO, CANCER BUCAL

NSINO ODONTOLOGICO, CLINICA INTEGRADA

NSINO ODONTOLOGICO, DISCIPLINA DE ODONTO SOCIAL

NSINO ODONTOLOGICO, INFLUENCIA NA PRATICA ODONTOLOGICA

NSINO ODONTOLOGICO, PIDA

NSINO ODONTOLOGICO, PROCESSO ENSINO-APRENDIZAGEM

PI CANCER

PI CANCER BMF

PI CANCER EM REGIAO DO EST DE SP

PI CANCER, GLANDULAS SALIVARES

PI CANCER, PAPEL DO CD

PI CANCER, PREVENTIVISMO

PI CARIE

PI CARIE EM BEBES

PI CARIE, ACAO DA GLICOSE E DA FRUTOSE NA DESCALCIFICAÇAO

PI CARIE, CASO DE ASSIMETRIA

PI CARIE, DIAGNOSTICO DE SAUDE EM ESCOLARES

PI CARIE, EPI PERIO, LESOES CAV BUCAL, IDOSOS

PI CARIE, ESCOLARES

PI CARIE, ESCOLARES DA AMAZONIA

PI CARIE, ESCOLARES, ACAO PROGRAMATICA

PI CARIE, ESCOLARES, FLUORETAÇAO DA AGUA

PI CARIE, FLUORETAÇAO DA AGUA

PI CARIE, MODELO EXPERIMENTAL IN VIVO

PI CARIE, NIVEL SOCIO-ECONOMICO MEDIO-ALTO

PI CARIE, OCUPAÇAO DA MAE

PI CARIE, PREVALENCIA EM AREA DE FLUOROSE ENDEMICA

PI CARIE, RAÇA, SEXO, IDADE, RENDA

PI CARIE, RELAÇAO COM MANCHAS EXTRINSECAS

PI CARIE, SIMPLIFICAÇAO DE INDICE DE CARIE

PI CARIE, SIMPLIFICAÇAO DO INDICE CPO

PI LESOES CAV BUCAL

PI MA OCLU

PI MA OCLU, ESCOLARES

IPI MA OCLU, FATORES SOCIO-ECONOMICOS

'PI MA OCLU, HABITOS DE SUCÇAO

IPI MA OCLU, PERDA PREMATURA DE MOLARES DECIDUOS

IPI PERIO

IPI PERIO, AVALIAÇAO DO CPITN

IPI PERIO, EDUCAÇAO EM SAUDE

IPI PERIO, EDUCAÇAO EM SAUDE EM ADULTOS

IPI PERIO, IDOSOS

'PI PERIO, INDICE DE RUSSEL

$1 \quad 0.3 \%$

$20.5 \%$

$1 \quad 0.3 \%$

$10.3 \%$

$10.3 \%$

$10.3 \%$

$1 \quad 0.3 \%$

$10.3 \%$

$2 \quad 0.5 \%$

$1 \quad 0.3 \%$

$1 \quad 0.3 \%$

$10.3 \%$

$1 \quad 0.3 \%$

$1 \quad 0.3 \%$

$30.8 \%$

$2 \quad 0.5 \%$

$2 \quad 0.5 \%$

$1 \quad 0.3 \%$

$1 \quad 0.3 \%$

$1 \quad 0.3 \%$

$1 \quad 0.3 \%$

$1 \quad 0.3 \%$

$3 \quad 0.8 \%$

$10.3 \%$

$10.3 \%$

$1 \quad 0.3 \%$

$10.3 \%$

$10.3 \%$

$82.1 \%$

$1 \quad 0.3 \%$

$1 \quad 0.3 \%$

$1 \quad 0.3 \%$

$2 \quad 0.5 \%$

$1 \quad 0.3 \%$

$1 \quad 0.3 \%$

$10.3 \%$

$1 \quad 0.3 \%$

$1 \quad 0.3 \%$

$1 \quad 0.3 \%$

$1 \quad 0.3 \%$

$1 \quad 0.3 \%$

$1 \quad 0.3 \%$

$20.5 \%$

$3 \quad 0.8 \%$

$1 \quad 0.3 \%$

$1 \quad 0.3 \%$

$1 \quad 0.3 \%$

$1 \quad 0.3 \%$

$10.3 \%$

$1 \quad 0.3 \%$

$1 \quad 0.3 \%$

$1 \quad 0.3 \%$

$1 \quad 0.3 \%$ 
I PERIO, NECESSIDADES DE TRATAMENTO PERIODONTAL

I PERIO, PRE-ESCOLARES

I PERIO, SIMPLIFICAÇAO DO INDICE GENGIVAL

I PERIO, TABAGISMO

JONOMIA, AMBIENTE DE TRABALHO E PRODUTIVIDADE

JONOMIA, ASPECTOS AMBIENTAIS

JONOMIA, ASPECTOS DOS EQUIPAMENTOS

JONOMIA, DESEMPENHO LOGICO

JONOMIA, GINASTICA E PREPARO FISICO DO CD

JONOMIA, POSIÇOES DE TRAB PARA CD E AUXILIAR/1

IONOMIA, POSIÇOES DE TRAB PARA CD E AUXILIAR/2

JONOMIA， POSTURA

3ONOMIA, POSTURAS DE DENTISTAS E AUXILIARES

JONOMIA， PRODUTIVIDADE DE ALUNOS SOS E AUXILIADOS

JONOMIA, TEC 4 MAOS, COORDENAÇAO CD/AUXILIAR EM PERIO

JONOMIA, TRABALHO A QUATRO MAOS

IOVA DE DENTES, DESGASTE DAS CERDAS COM O USO

בOVA DE DENTES, INFLUENCIA DA PONTA NA LIMPEZA DOS DENTES

IOVA DE DENTES, INTERAÇAO DE CERDAS COM DENTIFRICIOS

IOVA DE DENTES, MICROSCOPIA ELETRONICA DE VARREDURA

IOVA DE DENTES, PONTA DAS CERDAS

IOVA DE DENTES, PONTAS DAS CERDAS

ZOVA DE DENTES, PREFERENCIA, USO E SUBSTITUIÇAO

ZOVA DE DENTES, USO

IOVA DE DENTES, USO E CONSERVAÇAO ENTRE ESCOLARES

IOVAÇAO DENTARIA, ANALISE DE PESQUISAS

IOVAÇAO DENTARIA, FREQUENCIA ENTRE ESCOLARES

ZOVAÇAO DENTARIA, INFLUENCIA SOBRE CONDIÇAO GENGIVAL

IOVAÇAO DENTARIA, MOTIVAÇAO ENTRE ESCOLARES

IOVAÇAO DENTARIA, NUMERO DE MOVIMENTOS PARA REMOÇAO PLACA

IATURA, ESTIMATIVA A PARTIR DE DENTES MANDIBULARES

IDENCIADOR DE PLACA, COMPORTAMENTO DE ESTUDANTES DE ODONTO

) DENTAL, CAPACIDADE DE ABSORCAO

) DENTAL, EFICACIA DE DUAS TECNICAS

) DENTAL, USO

JOR GEL, AVALIAÇAO EM HUMANOS

JOR GEL, AVALIAÇAO LABORATORIAL

JOR GEL, INCORPORAÇAO DE FLUOR NO ESMALTE

JOR, AÇAO EM ADULTOS

JOR, BENEFICIOS E CONTROVERSIAS

JOR, CARIOLOGIA E PREVENÇAO

JOR, ESTABILIDADE EM AMOSTRAS DE AGUA

JOR, FFA, ATF, PREVENÇAO DE CARIE

JOR, FORMAS DE UTILIZAÇAO

JOR, IMPORTANCIA DO USO EM COMUNIDADES

JOR, INCORPORAÇAO DURANTE GESTAÇAO DE RATAS

JOR, INFLUENCIA NA RIZOLISE E RIZOGENESE

JOR, INTOXICAÇAO AGUDA

JOR, PREVENÇAO DE CARIE E RISCO DE CANCER

JOR， REATIVIDADE

JOR, TEOR EM AGUA FERVIDA

JOR, USO E SEGURANÇA

JOR, VERNIZ 
'LUOR, VERNIZES

'LUORETAÇAO DA AGUA

'LUORETAÇAO DA AGUA, CONDIÇAO GENGIVAL

'LUORETAÇAO DA AGUA, CONTROVERSIAS

'LUORETAÇAO DA AGUA, EFICACIA COM DESCONTINUIDADES

'LUORETAÇAO DA AGUA, EPI CARIE

'LUORETAÇAO DA AGUA, EPI CARIE, EX CLINICO E RADIOGRAFICO

'LUORETAÇAO DA AGUA, EVOLUÇAO EM PORTO ALEGRE

'LUORETAÇAO DA AGUA, HISTORICO EM PORTO ALEGRE

'LUORETAÇAO DA AGUA, TEOR EM AGUAS DA REGIAO DE RIB PRETO-SP

'LUORETAÇAO DO AÇUCAR

'LUORETAÇAO DO SAL DE COZINHA, ESTUDO METABOLICO

'LUORETAÇAO DO SAL DE COZINHA, PREPARO NO DOMICILIO

'LUORETAÇAO DO SAL DE COZINHA, PROGRAMA MUNICIPAL

'LUORETAÇAO DO SAL NO BRASIL, OPORTUNIDADE

'LUORETAÇ\|O DO SAL DE COZINHA, PREVENÇAO DE CARIE

'LUOROSE DENTARIA, ENDEMIA

'LUOROSE DENTARIA, EPIDEMIOLOGIA

'LUOROSE DENTARIA, PERCEPÇAO COMUNITARIA

'ORÇA DE TRABALHO EM SAUDE BUCAL

IOMA DE MASCAR, COMPOSIÇAO, MECANISMO DE AÇAO

IOMA DE MASCAR, EMPREGO NA PREVENÇAO DE CARIE

IIGIENE BUCAL, CONHECIMENTOS E HABITOS ENTRE POLICIAIS MILIT

IIGIENE BUCAL, CUSTO SOCIAL EM SALVADOR

IIGIENE BUCAL, EPI CARIE, EPI PERIO EM DIABETICOS

IIGIENE BUCAL, ESCOVAÇAO E COND GENGIV PAC C LESAO LABIO-PAL

IIGIENE BUCAL, HABITOS

IIGIENE BUCAL, HABITOS DE HIGIENIZAÇAO DE PROTESES TOTAIS

IIGIENE BUCAL, LIMP INTERPRX, FIO DENT, PALIT, ESCOV MONOTUF

IIGIENE BUCAL, MOTIVAÇAO DE ESCOLARES

IIGIENE BUCAL, MOTIVAÇAO DE POLICIAIS MILITARES

IIGIENE BUCAL, SIMPLIFICAÇAO DO INDICE

IIGIENE BUCAL, TECNICAS DE MOTIVAÇAO

AASER, USOS NA PREVENÇAO

IA OCLU, HABITOS DE SUCÇAO

IERCADO DE TRABALHO ODONTOLOGICO

IERCADO DE TRABALHO, DIREITOS DO CD EMPREGADO

IERCADO DE TRABALHO, DOIS CONSULTORIOS PARA AUMENTAR DEMANDA

IERCADO DE TRABALHO, NUMERO DE CD

IERCADO DE TRABALHO, PERSPECTIVAS DO CD POS-GRADUAÇAO

IERCADO DE TRABALHO, QUANDO E ONDE TRABALHA O CD PARTICULAR IERCURIO, CONTAMINAÇAO DO CD

IERCURIO, CONTAMINAÇAO NA PRATICA ODONTOLOGICA

IERCURIO, EFEITO EM DENTISTAS

IERCURIO, NIVEIS NOS CABELOS DE ESTUDANTES DE ODONTOLOGIA

IERCURIO, RISCO OCUPACIONAL NA PRATICA ODONTOLOGICA

IERCURIO, TOXICIDADE

IOTIVAÇAO, EDUCAÇAO EM SAUDE

IOTIVAÇAO, REDUÇAO FREQ INGESTAO AÇUCARES ENTRE ESCOLARES

IECESSIDADES DE TRATAMENTO, EPI CARIE, EPI PERIO

IECESSIDADES DE TRATAMENTO, PERCEPÇAO

IECESSIDADES DE TRATAMENTO, PERIO EM JOVENS MILITARES

IDONTOLOGIA DO TRABALHO

$10.3 \%$

$30.8 \%$

$10.3 \%$

$10.3 \%$

$10.3 \%$

$30.8 \%$

$10.3 \%$

$10.3 \%$

$10.3 \%$

$10.3 \%$

$10.3 \%$

$1 \quad 0.3 \%$

$10.3 \%$

$1 \quad 0.3 \%$

$1 \quad 0.3 \%$

$1 \quad 0.3 \%$

$10.3 \%$

$1 \quad 0.3 \%$

$1 \quad 0.3 \%$

$10.3 \%$

$1 \quad 0.3 \frac{\circ}{6}$

$10.3 \%$

$1 \quad 0.3 \%$

$1 \quad 0.3 \%$

$1 \quad 0.3 \%$

$10.3 \%$

$3 \quad 0.8 \%$

$10.3 \%$

$10.3 \%$

$1 \quad 0.3 \%$

$1 \quad 0.3 \%$

$1 \quad 0.3 \%$

$10.3 \%$

$10.3 \%$

$10.3 \%$

$1 \quad 0.3 \%$

$1 \quad 0.3 \%$

$10.3 \%$

$10.3 \%$

$10.3 \%$

$10.3 \%$

$10.3 \%$

$1 \quad 0.3 \%$

$10.3 \%$

$10.3 \%$

$10.3 \%$

$1 \quad 0.3 \%$

$10.3 \%$

$10.3 \%$

$10.3 \%$

$1 \quad 0.3 \%$

$10.3 \%$

$2 \quad 0.5 \%$ 
'ERIODICOS ODONTOLOGICOS, TEMPO DE VIDA 'ESSOAL AUXILIAR

'ESSOAL AUXILIAR EM ODONTOLOGIA

'LACA, AÇAO DO FLUOR NA PRODUÇAO ACIDA

'LACA, CONTROLE COM CLORETO DE CETILPIRIDINIO MAIS FLUOR

'LACA, CONTROLE FISICO E QUIMICO

'LACA, CONTROLE MECANICO

'LACA, CONTROLE MECANICO COM FIO DENTAL

'LACA, CONTROLE MECANICO COM INSTRUMENTO ARTESANAL

'LACA, CONTROLE MECANICO E QUIMICO DA PLACA

'LACA, CONTROLE QUIMICO

'LACA, CONTROLE QUIMICO COM BOCHECHOS PRE-ESCOVAÇAO

'LACA, CONTROLE QUIMICO COM CLORETO DE CETILPIRIDINIO

'LACA, CONTROLE QUIMICO COM GLUCONATO DE CLOREXIDINA

'LACA, CONTROLE QUIMICO COM GOMA DE MASCAR

'LACA, CONTROLE QUIMICO COM SANGUINARINA

'LACA, CONTROLE QUIMICO COM SOLUÇOES PRE-ESCOVAÇAO

'LACA, CONTROLE QUIMICO COM SULFATO DE COBRE

'LACA, FORMAÇAO IN VITRO POR AÇUCAR MASCAVO

'LACA, METABOLISMO

OLITICAS DE SAUDE BUCAL NO BRASIL

'RATICA ODONTOLOGICA

'RATICA ODONTOLOGICA NO SETOR PUBLICO

'RATICA ODONTOLOGICA NO SISTEMA NACIONAL DE SAUDE CUBANO

'RATICA ODONTOLOGICA, CODIGO DE DEFESA DO CONSUMIDOR E O CD

'RATICA ODONTOLOGICA, EQUIPAMENTOS UTILIZADOS PELOS CDS

'RATICA ODONTOLOGICA, ESTABILIDADE DE EMPREGADOS DE CD

'RATICA ODONTOLOGICA, ESTRESSE DO CIRURGIAO-DENTISTA

'RATICA ODONTOLOGICA, EVOLUÇAO

'RATICA ODONTOLOGICA, EXPECTATIVAS E DIFICULDADES DO CD

'RATICA ODONTOLOGICA, HIPNOSE

'RATICA ODONTOLOGICA, PARTICIPAÇAO POPULAR

'RATICA ODONTOLOGICA, PROCEDIMENTOS DE PROTEÇAO

'RATICA ODONTOLOGICA, QUALIDADE DA AGUA USADA NA CLINICA

'RATICA ODONTOLOGICA, QUESTIONARIO DE SAUDE

'RATICA ODONTOLOGICA, RADIOGRAFIA NA PERICIA ODONTOLEGAL

'RATICA ODONTOLOGICA, RADIOPROTEÇAO

'RATICA ODONTOLOGICA, REALIZAÇAO PROFISSIONAL DO CD

'RATICA ODONTOLOGICA, RELAÇAO PROFISSIONAL-PACIENTE

'RATICA ODONTOLOGICA, TEMPOS DE PROCEDIMENTOS

'RATICA ODONTOLOGICA, TRANSMISSAO DE DOENÇAS

'RATICA ODONTOLOGICA, TRANSMISSAO DE DOENÇAS COND AMBIENTAIS

'RATICA ODONTOLOGICA, TRANSMISSAO DE DOENÇAS, PROTEÇAO

'RATICA ODONTOLOGICA, TRANSMISSAO DE HIV

'RESCRIÇAO DE MEDICAMENTOS PELO CD, ASPECTOS LEGAIS E ETICOS 'REVENÇAO DE CARIE

'REVENÇAO DE CARIE E PERIO, RECURSOS DIDATICOS DE MOTIVAÇAO

'REVENÇAO DE CARIE EM CONSULTORIO PARTICULAR

'REVENÇAO DE CARIE, ASSOCIAÇAO DE METODOS

'REVENÇAO DE CARIE, BOCHECHOS COM FLUOR

'REVENÇAO DE CARIE, BOCHECHOS COM FLUOR, ESCOLARES

'REVENÇAO DE CARIE, CHA, MATE, FLUORETAÇAO DA AGUA

'REVENÇAO DE CARIE, CONSULTA PREVENTIVA

$1 \quad 0.3 \%$

$1 \quad 0.3 \%$

$1 \quad 0.3 \%$

$1 \quad 0.3 \%$

$10.3 \%$

$1 \quad 0.3 \%$

$2 \quad 0.5 \%$

$1 \quad 0.3 \%$

$1 \quad 0.3 \%$

$1 \quad 0.3 \%$

$5 \quad 1.3 \%$

$1 \quad 0.3 \%$

$1 \quad 0.3 \%$

$1 \quad 0.3 \%$

$3 \quad 0.8 \%$

$1 \quad 0.3 \%$

$1 \quad 0.3 \%$

$1 \quad 0.3 \%$

$1 \quad 0.3 \%$

$1 \quad 0.3 \%$

$1 \quad 0.3 \%$

$1 \quad 0.3 \%$

$1 \quad 0.3 \%$

$1 \quad 0.3 \%$

$1 \quad 0.3 \%$

$1 \quad 0.3 \%$

$1 \quad 0.3 \%$

$1 \quad 0.3 \%$

$1 \quad 0.3 \%$

$1 \quad 0.3 \%$

$10.3 \%$

$1 \quad 0.3 \%$

$1 \quad 0.3 \%$

$1 \quad 0.3 \%$

$1 \quad 0.3 \frac{8}{6}$

$1 \quad 0.3 \%$

$1 \quad 0.3 \%$

$1 \quad 0.3 \%$

$1 \quad 0.3 \%$

$1 \quad 0.3 \%$

$92.3 \%$

$1 \quad 0.3 \%$

$1 \quad 0.3 \%$

$1 \quad 0.3 \%$

$1 \quad 0.3 \%$

$1 \quad 0.3 \%$

$1 \quad 0.3 \%$

$1 \quad 0.3 \%$

$2 \quad 0.5 \%$

$1 \quad 0.3 \%$

$1 \quad 0.3 \%$

$1 \quad 0.3 \%$

$1 \quad 0.3 \%$ 
'REVENÇAO DE CARIE, CONSULTORIO PARTICULAR

'REVENÇAO DE CARIE, DIAMINO FLUORETO DE PRATA

'REVENÇAO DE CARIE, EDUCAÇAO EM SAUDE DO PRE-ESCOLAR

'REVENÇAO DE CARIE, ELEMENTOS TRAÇOS

'REVENÇAO DE CARIE, ESCOLARES

'REVENÇAO DE CARIE, OXALATO DE CALCIO, CARBONATO DE CALCIO

'REVENÇAO DE CARIE, PRATICA DA EDUCAÇAO EM SAUDE

'REVENÇAO DE CARIE, PROCESSO DES-RE DO ESMALTE

'REVENÇAO DE CARIE, RELAÇAO AÇUCAR-CARIE

'REVENÇAO, ASPECTOS SOCIAIS

'RIMEIROS MOLARES, COND CLINICAS EM ESTUDANTES COM ASSIST OD 'ROCESSO SAUDE-DOENÇA, HOLISTICA

ROCESSO SAUDE-DOENÇA, REPRESENTAÇAO SOCIAL

ROFISSAO ODONTOLOGICA, MOTIVAÇAO PARA A ESCOLHA

ROGRAMA NACIONAL DE CONTROLE DA CARIE COM SELANTES E FLUOR

ROMOÇAO DA SAUDE BUCAL

ADIAÇAO, PREVENÇAO DE CARIE

ECURSOS HUMANOS ODONTOLOGICOS, ATUALIZAÇAO

ECURSOS HUMANOS ODONTOLOGICOS, POLITICAS DE FORMAÇAO

ECURSOS HUMANOS, ESTUDANTE DE ODONTO, PERFIL DO INGRESSANTE

ECURSOS HUMANOS, PARTICIPAÇAO DO THD EM SERV PUBL MUNICIPAL ECURSOS HUMANOS, PARTICIPAÇAO THD NA PRATICA ODONTOLOGICA ECURSOS HUMANOS, TREINAMENTO ODONTOLOGICO DE INDIOS TICUNAS ISCO DE CARIE, DETERMINAÇAO

ALIVA E SAUDE BUCAL

ALIVA, CAPACIDADE DE TAMPONAMENTO FRENTE A DENTIFRICIOS ALIVA, CINETICA DO FLUOR

ALIVA, FLUXO E CAPACIDADE TAMPAO

ALIVA, NIVEIS DE S MUTANS E RELAÇAO COM VARIAVEIS CLINICAS

AUDE BUCAL NO BRASIL

AUDE BUCAL, AVALIAÇAO DE UM PROGRAMA

AUDE BUCAL, CONDIÇOES EM ESCOLARES DE AREA RURAL

AUDE BUCAL, CONDIÇOES EM IDOSOS DO MUN SP

AUDE BUCAL, EPIDEMIOLOGIA DA DOENÇAS BUCAIS

AUDE BUCAL, EPIDEMIOLOGIA DAS DOENÇAS DENTARIAS

AUDE BUCAL, MANUTENÇAO: CONHECIMENTOS DE CLIENTELA DE CS

AUDE BUCAL, PERCEPÇAO POPULAR DE GESTANTES

AUDE BUCAL, PROGRAMA

AUDE BUCAL, PROGRAMA MUNICIPAL

AUDE BUCAL, PROGRAMA MUNICIPAL PARA ESCOLARES

AUDE BUCAL, PROGRAMA MUNICIPAL PARA PRE-ESCOLARES

AUDE BUCAL, PROGRAMAS DEMOCRACIA E PARTICIPAÇAO POPULAR

AUDE PUBLICA, O QUE E

ELANTE E PREVENÇAO DE CARIE

ILANTE, EMPREGO EM CARIES INCIPIENTES NA PREVENÇAO DA CARIE ILANTE, IDADE PARA APLICAÇAO

ILANTE, INFLUENCIA DA PROFILAXIA NA RETENCAO

ILANTE, PERIODO DE RETENÇ\|O E EFICACIA PREVENTIVA

ILANTE, PREVENÇAO DE CARIE

ILANTE， RETENCAO

ILANTE， RETENÇAO

ILANTE, RETENÇAO E EFICACIA ASSOCIADO A ATF

ILANTE, RETENÇAO EM DUAS TECNICAS DE APLICAÇAO 
JELANTE, RETENÇAO EM TRES DIFERENTES CONDIÇOES ¿ELANTE， RETENÇ\|O

¿ELANTE, USO EM SAUDE PUBLICA

¿ELANTE, USOS

ЭELANTE, UTILIZAÇAO EM CLINICA DE SAUDE PUBLICA

¿ERVIÇO PUBLICO ODONTOLOGICO, DIAGNOSTICO FRENTE AS AIS

IISTEMA DE SAUDE, ASSISTENCIA ODONTOLOGICA

IISTEMA DE SAUDE, AÇAO COMUNITARIA

IISTEMA DE SAUDE, CONSTITUINTE

IISTEMA DE SAUDE, MUNICIPALIZAÇAO

IISTEMA DE SAUDE, REFORMA SANITARIA E ENSINO ODONTOLOGICO

IISTEMA INCREMENTAL

IISTEMA INCREMENTAL, AVALIAÇAO

TAMANHO DE DENTES, CORRELAÇAO COM ALTURA-LARGURA DA FACE TRAUMATISMO BUCO-DENTARIO, PREVENÇAO

$1 \quad 0.3 \%$

$1 \quad 0.3 \%$

$1 \quad 0.3 \%$

$1 \quad 0.3 \%$

$1 \quad 0.3 \%$

$1 \quad 0.3 \%$

$2 \quad 0.5 \%$

$2 \quad 0.5 \%$

$1 \quad 0.3 \%$

$1 \quad 0.3 \%$

$1 \quad 0.3 \%$

$1 \quad 0.3 \%$

$1 \quad 0.3 \%$

$1 \quad 0.3 \%$

$10.3 \%$

Total $\quad 386 \quad 100.0 \%$ 